\title{
MODERN THOUGHT
} AND THE

CRISIS IN BELIEF

$$
\text { R. M. WENLEY }
$$




\section{BR 121 .W46 1909 Wenley, Robert Mark, $1861-$ Modern thought and the crisis in belief}


THE BALDWIN LECTURES, 1909

\section{MODERN THOUGHT AND THE CRISIS IN BELIEF}




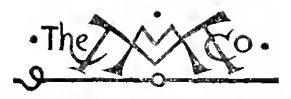

THE MACMILLAN COMPANY NEW YORK - BOSTON - CHICAGO ATLANTA - SAN FRANCISCO

MACMILLAN \& CO., Limited

LONDON - BOMBAY - CALCUTTA

MELBOURNE

THE MACMILLAN CO. OF CANADA, Ltd. TORONTO 


\title{
THE BALDIVIN LECTURES, 1909
}

\section{MODERN THOUGITT AND THE CRISIS IN BELIEF}

\author{
BY \\ R. M. WENLEY \\ D.Phil., Hon. LL.D. (Gias.), Sc.D., F.R.S. (Edin.), \\ HoN. LitT.D. (HOBART)
}

Xrom 39ark

THE MACMILLAN COMPANY

I 909

All rights reserved 
Cofyright, rgog,

BY THE MACMILLAN COMPANY.

Set up and electroty ped. Published March, igog.

Norwood 13 ress

I. S. Cushing Co. - Berwick \& Smith Co.

Sorwood, Mass., I..... 

"La pensée semble d'abord n'être que l'esquisse affaiblie des choses; elle est mieux: elle en est l'idéalisation vivante, en voie de réalisation"

- Fonillée.

" The historic personage

Put by, leaves prominent the impulse of his age ;

Truth sets aside speech, act, time, place, indeed, but brings Nakedly forward now the principle of things Highest and least."

- Browning.

"Und diess Geheimniss redete das Leben selber zu mir: 'Siehe,' sprach es, ‘ich bin Das, was sich immer selber überwinden muss." "

- Nietzsche. 


\section{ORIGIN OF THE FOUNDATION AND EXTRACT FROM THE DEED OF TRUST}

Having regard to the peculiar conditions at the State Universities, where students of all denominations stand on an equal footing, and where, therefore, no theological faculties can be erected, the Right Reverend Samuel Smith Harris, Bishop of the Protestant Episcopal Church in the Diocese of Michigan, in I885, executed a Deed of Trust with certain influential laymen of his diocese. This was one of the first steps in what is known as the Guild Movement, now widespread and still growing. The Guilds are representative of the various denominations, and, as a rule, maintain their own halls, with libraries, reading rooms, gymnasia, etc., as headquarters for their students, and as centres of religious activity supplementary to their local churches. Lectureships often form a part of their plan. Thus, as a result of Bishop Harris's efforts, Harris Hall was built and endowed, to be the headquarters for all members and adherents of the 
Protestant Episcopal Church who are teachers or students in the University of Michigan. The Hobart Guild was instituted to use and to govern the Hall. The Baldwin and Slocum Lectureships were founded, with adequate subventions, due also to Bishop Harris's enthusiasm. They are delivered in alternate years.

The portion of the Deed aforesaid, relating to the Baldwin Lectures, runs as follows:-

"Now, therefore, I, the said Samuel Smith Harris, Bishop as aforesaid, do hereby give, grant, and transfer to the said Henry P. Baldwin, Alonzo B. Palmer, Henry A. Hayden, Sidney D. Miller, and Henry P. Baldwin, 2d, Trustees as aforesaid, the said sum of ten thousand dollars to be invested in good and safe interest-bearing securities, the net income thereof to be paid and applied from time to time as hereinafter provided, the said sum and the income thereof to be held in trust for the following uses:-

"I. The said fund shall be known as the Endowment Fund of the Baldwin Lectures.

"2. There shall be chosen annually by the Hobart Guild of the University of Michigan, upon the nomination of the Bishop of Michigan, a learned clergyman or other communicant of the Protestant 
Episcopal Church, to deliver at Ann Arbor and under the auspices of the said Hobart Guild, letween the Feast of St. Michael and All Angels and the Feast of St. Thomas, in cach year, not less than six nor more than eight lectures, for the Establishment and Defence of Christian Truth; the said lectures to be published in book form by Easter of the following year, and to be entitled 'The Baldwin Lectures'; and there shall be paid to the said lecturer the income of the said endowment fund, upon the delivery of fifty copies of said lectures to the said Trustees or their successors; the said printed volumes to contain, as an extract from this instrument, or in condensed form, a statement of the object and conditions of this trust." 



\section{PREFACE}

Speaking in the House of Commons several years ago, that eminent and deroted churchman, Lord Hugh Cecil, expressed himself as follows: "On all sides there are signs of decay of the Faith. People do not go to church, or, if they go, it is for the sake of the music, or for some non-religious motive. The evidence is overwhelming that the doctrines of Christianity have passed into the region of doubt." Once more, the Bishop of Carlisle has affirmed: "There are, perhaps, few things, and certainly nothing of similar moment, about which men give themselves so little trouble, and take such little pains, as the ascertainment, by strict examination, of the foundations and the evidences of their religion." Outspoken and weighty statements by responsible persons seldom lack foundation in fact. Accordingly, in these Lectures, I have attempted a partial review of the situation, so far as my narrow limits permit. Thus, in Lecture I, I have drawn attention to the alterations that overtake reflective constructions of belief. In Lectures II-IV, I have $\mathrm{xi}$ 
made an effort to summarize movements that justify Lord Hugh Cecil's declaration. But, as I have borne no part in the work of physical science and higher criticism, I am able only to indicate the present view from the conclusions of others. In Lectures V-VIII, I have essayed, in my own way, the examination suggested by the Bishop of Carlisle. I cannot pretend to expert familiarity with theology, so I have deemed it wiser to abandon this standpoint, represented most adequately by many others, and have confined myself to matters where I am more at home.

It is obvious, to students at least, that we are passing through a stage of transition where hazards beset belief. Of course, I am well aware that a broad distinction survives between the "beliefs of the vulgar and of the learned," as they have been called. But, under the educational arrangements prevalent now, - and these Lectures are to hold them in special remembrance, - it tends to fade, with two results. On the one hand, some who deem themselves 'learned' hug the idea that religion has become a negligible quantity. Their learning has not matured enough to make manifest the deeps of our remanent ignorance. On the other hand, many are puzzled, often distressed beyond measure, by 
the metamorphic process coincident with enquiry. They resent the stress placed upon natural piety, and so they blink the issue, to sore harm of the religious cause; or, unappreciative of what knowledge has gleaned, they cling to belief of such a character that, under assault, it can scarce be distinguished from the despair of a last resort. These are sad hazards.

It were useless, possibly dangerous, to keep the 'vulgar' in ignorance of the "wood, hay, stubble man's work," and therefore subject to loss, especially as we still stand on the threshold of some scientific and historical studies, more particularly those destined to affect our views of the conditions and nature of self-consciousness, and of the precise environment whereout the New Testament and early Christianity sprang. It were cruel, possibly criminal, to keep the "learned' in ignorance of "the things which cannot be shaken," for, in preoccupation with corners of the garden, they are apt to miss a just estimate of their own general presuppositions. As a student, speaking in an academic community, I have tried to show why, and to indicate some reasons for doubting doubt that remains merely destructive. At the same time, my readers must bear in mind that Lectures addressed to a general audience 
cannot be more than tentative. This ought to be realized especially in connexion with the purely illustrative uses to which I have put the ethical consciousness.

Nobody knows so well as I the inadequacy of my equipment for this difficult task; and few can have had better reason to know how its prosecution calls down anathemas alike from defenders of "the faith once delivered to the saints" - for whom religion has achieved finality - and from rationalists who, in their horror of the sympathetic fallacy, cherish the notion that technical research can accomplish a perfect work. These I cannot hope to conciliate, much less to convince. Time, that tries all, must be their teacher. But for such as believe that "the establishment of Christian truth," rather than its apologetic defence or contemptuous dismissal, is an important part of the second Reformation imposed upon us by the contemporary course of science and scholarship, I trust I have touched some things worth further reflexion.

In any event, I have no apology to offer for my view that religion is of primary importance to mankind. Belief bears its recompenses, because our fragmental nature makes insistent demand for completion. 
I extend cordial thanks to several eminent scholars who have taken the trouble to rearl portions of my manuscript, ant to sugsest improvements. They are not to be held responsible in any sense for my errors or my opinions.

R. M. WENLEy. 


\section{CONTENTS}

\section{LEC'TURE I}

PAGE

Sheaves on the Threshing-FloOR . . . . I

Introduction . $\quad$ - . . . . . I

The New Attitude of Culture to Religion . . 3

The Nature of Intellectual Constructions . . I I

The Instability of Intellectual Constructions . . 27

\section{LECTURE II}

The Waters of Meribail • • • • 4 . 4

Supposition and Science . . . . . . 46

The Scientific Consciousmess in its Methods and

Conclusions ..$\quad$. .54

LECTURE III

Breaciles of the House . . . . . . $8 \mathbf{I}$

The Historico-critical Movement . $\quad . \quad$. $\quad$. $\quad 82$

I. Ancient History . . . . . 100

2. The Old Testament . . . . . IIt

LECTURE IV

Humliation in the Midst . . . . . ifo

The Historico-critical Movement (continued) . Ifo

3. The New Testament. . . . . I i r

4. Christian Syncretism . . . . . 175 


\section{LECTURE $V$}

The Preestablished Discord . . . . . 190

The Roots of Conflict in Experience . . . I94

The Abstractions of Science and their Meaning;

Consequent Discords . . . . . . 200

The Discord as it appears within Historical Science $22 \mathrm{I}$

Man forced to seek Refuge in the Ethical Conscious-

ness $\quad . \quad . \quad . \quad . \quad . \quad . \quad . \quad 230$

\section{LECTURE VI}

The Adjournment of Well-being . . . . 232

Religion and the Ethical Consciousness . . 233

Teleology and Discontinuity . . . . . 237

The Time-series and the Ethical Consciousness . 245

Failure of the Ethical Consciousness to satisfy Man 25I

The Passage to Religion . . . . . 256

\section{LECTURE VII}

The Penumbra of Belief . . . . . . 278

Knowledge and Life . . . . . . 278

The Mystic Element in Religion . . . . . 289

The Nature of Christian Conviction • • . 297

What think ye of Christ? . . . . 312

\section{LECTURE VIII}

The Valley of Blessing. . . . . . 324

Religion under the Conditions of Experience . $\quad 324$

Christianity as a Missionary Religion . . 325

Christianity and Secular Polity . . . 332

Christianity as a Process: Absoluteness and Change 344 Conclusion . . . . . . . . . 358 
MODERN THOUGHT AND THE CRISIS IN BELIEF 
, 


\section{MODERN THOUGHT AND THE CRISIS IN BELIEF}

\section{LECTURE I}

SHEAVES ON THE THRESHING-FLOOR

The invitation of the Bishop and the Hobart Guild, calling a layman to deliver these Lectures for the first time, can hardly pass without comment. Inevitably, I must cut a sorry figure by comparison with my eminent clerical predecessors. Yet, paradoxically, the very fact that a layman lacks professional bias may serve as a makeweight. In all professions the initiate tends to fall under the sway of certain conventions. Indeed, were this not so, professions as such would cease to exist. Thus, in dealing with professional subjects, the accredited member of the craft inclines to accept a distinct standpoint whereto he has grown, almost unconsciously, through long years of training and association. Nay, the more he has earned the right to appear as an adequate representative, the further, 
as a rule, has this assimilation proceeded. I am unaware that the clergy are greater sinners in such respect than their brethren of the bar or the desk, the sword or the lancet, even if their public function, in preaching, render them a readier prey to facile criticism. For every profession develops its 'system,' its 'form,' its 'ethics,' its what-not.

In the circumstances inseparable from these Lectures, the tendency of the clerical 'system' might result, conceivably, in partial failure to distinguish between theology and religion, between creed and conduct, between the church and Christianity, or the like. So, once in a great while, it may prove refreshing, if perilous, to expose the lay mind, even with all its sins of feeble technique upon its head. Again, one passes no impertinent reflexion in saying that the clerical attitude towards religion is defensive, in large measure. Nay, we laity force this upon our ministers by our determination to hold them men of other flesh, of other mould, than curselves. Accordingly, let us bear the blame, great or small, when we repeat the acute remark, "It is the mischief of the defensive method that the class of facts against which a man has made himself impregnable may be the very class of facts which it is his chief business to know." More than likely, 
your layman may have been placed midmost these very facts in his daily work. If not, he may recall the trite doctrine, that a spectator sometimes understands more of the fight than those who are in the thick of it. In any event, he can add at least, especially as concerns religion, that he suffers the same frailty with all his fellows; for he is the same sinner, the same subject of ceaseless craving for -

"The light that nerer was on sea or land,"

the same wistful suppliant for-

"the wings of faith, to rise

Within the veil, and . . .

Possess the promiscd rest."

It would be superfluous to adduce proofs of the statement that, in a single generation, the position of English-speaking folk towards 'Christian truth' has undergone large displacement. So much is quite sure. Moreover, one must remark, not merely that this change continues, but rather that its influence affects wider and wider circles. It is no part of my aim meanwhile to deploy reasons for the modification. But one fact, slurred too often just now, merits comment. Obviously enough, man's estimate even of the deepest things of life 
alters in face of new knowledge of nature, especially of organisms, brute and human. Darwin was the -

"Calm priest of a tremendous oracle."

Yet, after all, the world, with its objects, vital or non-vital, maintains a certain aloofness from those ethical, rsthetic, and religious insights that serve at once to differentiate man and to set his distinctive problems. No amount of sophistication suffices to obliterate the contrast between things, or stable bodies, in the objective realm, and processes, or inconstant successions, in the subjective sphere. Despite their manifold, inclelible relations, they remain two orders, amenable, perhaps, to similar methods of research, but always so amenable in different measure and with very contrasted degrees of success.

We shall not be surprised to learn, then, that "transvaluation of values" in matters religious must stand to the account rather of historical than of biological or physical investigation. Language and literature, conduct and institutions, custom and myth, society and law, worship and dogma, - these, with their kind, together constitute man's peculiar expression of his own nature. Thus, fresh results 
in anthropology, ethics, comparative religion, criticism, jurisprudence, ethnic psychology, and the history of civilization affect our estimates of the significance, sweep, and implications of our common humanity as no hypotheses concerning bodies, or even the body, ever can. Bcing human, -

"Some thought imprisons us; we set about To bring the world within the woven spell."

Now, Germany was the mother-land of these fateful 'human' sciences. 'There they had origin, grew, took definite shape, and found acceptance for nigh a century ere they penetrated the English world. Echoes were wafted overseas, indeed. But Coleridge and Carlyle, Emerson and Browning prophesied in the upper air to a stiff-necked generation. Their early audience would have little or none of them. " "Pauline,' a piece of pure bewilderment," said the London Athenaum, so late as 1833 ; and this was sixty-six years after Herder, "the gatekeeper of the nineteenth century," had published his epoch-making "Fragmente." Nay, a quarter century later, the greatest English scholar of the age, a man of monumental learning, seems to stay stranded outside the main current of European thought. For Whewell, in the third edition of his "History of the 


\section{MODERN THOUGHT AND THE CRISIS IN BELIEF}

Inductive Sciences" (1858), the enormous change wrought by Kant seventy-seven years before might as well not have taken place. Its real meaning is a mere vagrom rumour. Small wonder, then, that misrepresentation or, as oftener, sheer ignorance tangled the fundamental tendencies. Accordingly, Germany arrived at a gradual appreciation of the transitive principles peculiar to nineteenth-century thought by a slow, cumulative process, beginning with Winckelmann and Lessing about i760; passing through the several stages of Kant, Herder, Goethe, Fichte, Schelling, and the Romantics; coming finally to clear consciousness in Hegel, and that historico-critical upheaval for which he, more than any other single force, must be given credit. On the contrary, Great Britain and the United States enjoyed no such period of formative transition. For, all things considered, the movement burst upon them in full panoply of power during the decade I865-I875. Further, as if to accentuate the stress, it synchronized with the home-thrusting dispute over the Darwinian theory, and this at a moment when the essential identity of the two schemes, in ultimate attitude towards the universe, was not apparent. As always, controversy clouded the main issues at the outset. On the other hand, since about 
I890 shouts of battle have diminished, party cries and nicknames have found their due level, a process of assimilation has wrought results in some measure. We shall realize this more in detail later. Neanwhile, suffice it to say that we can now recognize the reason why our intellectual atmosphere has not been interpenetrated by these constructive ideas even yet. Astonishing darkness prevails in certain quarters, where illumination might be expected, while misconceptions so strange that one is forced to conclude them undesigned to mislead, still provide pitiful commentary. Nevertheless, we are bound to remember, in all charity, that when the waters of evolution rose and the floods of criticism descended at one fell swoop, dire shipwreck of their most holy things seemed imminent to many. But, in any case, perspective has altered. For example, it were impossible to-day that the hue and cry after the "Vestiges of the Natural History of Creation" (I844) should recur over a similar book. As Lamarck said, browbeaten by his generation, "It is better that a truth once perceived should struggle a long time to obtain attention than that everything the ardent imagination of man produces should be easily accepted." 1

${ }^{1}$ Philosophie Zoologique, p. I5. 
At this point let us pause to remind ourselves sharply of some phrases used above. 'New knowledge of nature,' 'fresh results in criticism,' 'human sciences,' 'dispute over the Darwinian theory,' and so forth. What do they imply? Or, shifting the angle slightly, Does the average man possess much lore concerning these things? The answer is, They imply that religion involves an important intellectual element, and that the average man, just on account of his ignorance, may find himself at the mercy of this element, to his comfort, or, as so often, to his deep distress. By way of introduction, I propose to consider the grave problems lurking here.

An obvious course would be to set out from that copy-book platitude, the distinction between religion and theology. According to this view, the two are related as antecedent and consequent. The prius of theology is religion; for theology represents the reaction of reason upon inexpressible aspirations that flow from the 'heart.' Or, once more, theology broods among the shadows of abstraction, while religion wells up naturally in the free manifestation of faith. Now, admitting that such contrasts may serve a purpose sometimes, it nevertheless remains true that they are too naive. No one needs to emphasize the evident differences between theory 
and practice, logic and life, the state and the citizen, pure and applied science; they float on the surface, naked and unashamed. Meaning attaches to them as aspects of a single whole, never as mutually exclusive facts. They appear as incidents of a dialectic movement, the one implies the other, and the problem roots in the nature of the connexion, never in the bare contrast. Whatever might be said of origins, we are unable to seck light in the darkness of the past; religion and theology so intertwine now that jejune and odious comparisons preclude any conclusion. To escape the consequent impasse another method must prevail. Our sole resource lies in an appeal to concrete experience. Religion cannot exist apart from some view of its necessary conditions, and these belong to human nature.

"Ein Traum, ein Traum ist unser Leben Auf Erden hier;

Wie schatten auf den Wogen schweben

Und schwinden wir;

Und messen uns're trägen Tritte

Nach Raum und Zeit, Und sind, und wissen's nicht, in Mitte Der Ewigkeit!"

Taken at its best, knowledge about man leaves much unknown and, very likely, unsuspected. We cannot tell how we came by our perception of space, 
with its wonderful localization of objects, surely a familiar affair. IVe know little about the brain, less about its intimate functioning as the organ of consciousness, nothing of the ultimate relation between the two; while our acquaintance with consciousness itself is lapped everywhere by the mighty ocean of ignorance. In the nature of the case, our inferences from the ascertained phenomena present themselves synoptically. That is to say, we must rest satisfied with results in gross, numerous factors being beyond reach meantime. Yet, even so, some points almost shout their presence. The reflective mind, at least, seizes them immediately. For example, beyond peradventure man's distinctive fate centres in his double life, - on the one hand, an animal moved to hunger and lust and cruelty, on the other, a subject of aspirations whereby he serves himself a little lower than the angels. The eternal conflict between these two sets all his problems, originates all his fears and sufferings, but at the same time baptizes him into all opportunity. At his sweet pleasure he can "idealize himself into dirt" with -

"a scrofulous French novel

On grey paper with blunt type,"

or into devilry, -

"Squat like a toad, close to the ear of Eve;" 
anon, led by -

"The Star of the unconquerable will,"

he may vault time and space, -

"Pouring heaven into this shut house of life."

Of a truth, then, we men grasp keys to most varied universes. These universes, in turn, together hold the secret of the problem now under examination. Accordingly, the question comes to be, (I) What import are we to attach to the term 'universe'; and (2) What 'universes' emerge if appeal be taken to experience?

(I) In the present connexion, formidable although it may seem, the word 'universe' need invoke no serious terrors. On the contrary, indeed, it is a simple commonplace. For instance, we declare, with perfect truth, that the American and the Englishman live in different 'universes.' Historical traditions, political organization, and social relationships differentiate their respective estimates of life. To the one a title imports less than nothing, to the other it carries a clear conventional value; to the one ownership of land implies little, on the other it bestows a distinct social status; the one conceives that money can effect almost anything, the other is well aware that some things, attractive to him, cannot be 
purchased. Again, take men in the same society. Contrast the successful merchant with the productive scholar. To the former the career of the latter spells failure - it does not pay; to the latter the career of the former misses full flavour - it does not pay in the right way, for it sacrifices the man to the bare pursuit. In a word, one of the most familiar facts of life finds illustration in the universal tendency to rate the same things differently, and by consequence to judge human affairs from divergent standpoints. The influences which, in sum, produce and maintain such phenomena we call a 'universe,' because it is the kind of totality forming the customary world wherein a man seeks his spiritual adventures. There he finds at once his aims and his motives. Anyone who cares to study, say, the proverbs of various peoples will grasp this immediately; opposed types of 'universe' are embodied in the wise saws of the folk.

Dropping these manifest comparisons, the real problem appears. If, on analysis, it result that mankind tends naturally, on the whole and without distinction of time or place, to reveal the occupancy of certain 'universes,' then our enquiry will have reached some conclusion.

(2) Luckily, Nature lends such efficient aid here 
that no recondite process nced ensue. For, whatever his limitations, every human being admits that his life presents two insistent aspects, neither of them to be escaped or palliated in serious measure. For better or worse, all occupy a physical and a psychical 'universe.' The contrast between things and thoughts forms the most evident, yet profoundest, occurrence in life. No one has the slightest difficulty in recognizing it, all assume it in the simplest functions and arrangements of the daily round. But the terms 'physical' and 'psychical' represent vast complexes which, to a certain extent, we not only can and do, but even must analyze. When I kick a stone or a man, I do not anticipate precisely identical reactions. We are prone to kick any stone, we have been known to select our man. Again, when I talk to a friend, or ponder some mighty achievement in history, I am perfectly aware of the great difference between the two events. Here, once more, Nature aids us by the very obviousness of her ways. Just as experience splits itself, without any effort on our part, into the 'physical' and the 'psychical,' so these subdivisions fissure in turn, and after equally spontaneous fashion. The 'physical' presents two unmistakable aspects, - things and living things, especially our own bodies. In 
I4 MODERN TIOUGHT AND THE CRISIS IN BELIEF

like manner, the 'psychical' hives off into self and other selves, the former dwelling almost breathlessly upon its possible future here and hereafter, the latter entrancing by their multitudinous past and puzzling present.

These four 'universes' envelop man at every moment. Negatively, he cannot flee from any one of them; positively, he may enter any one at will, and may mould his career in it more fully than in the rest. They are, then: (a) things, from the farthest star to the newest manufactured article; (b) living things, from the simplest unicellular organism to that organic community, amazing in its involution, known as the human body; $(c)$ other selves, from naked savages, the prey of natural forces, to strangely intertwined contemporary societies who harness wind and steam and electricity and ether so that they obey them; from wretched barbarians, whose idols are placated by unspeakable tortures, to Christian saints anxious to pour out their all if haply the reign of Jesus may advantage by never so little; (d) self, from the vague time it could say ' $I$ ' to those memorable moments when it thrills, or falters, or weeps over the -

"obstinate questionings

Of sense and outward things... 
Blank misgivings of a Creature

Moving about in worlds not realized,

High instincts before which our mortal Nature

Did tremble like a thing surprised."

Our psychological organization is so contrived that it rives the universal into these fractions, and continues thercafter under the main rule of one or another; consequently, the indivisible reality secludes itself afar. Here we meet the recurrent mystery of the One and the Many, an enigma since the oldest days of Hindustan and Greece. Yearning after the One, men are fated to work out thcir salvation in such a scramble of competitive aims that the task of unification seems hopeless or impracticable.

"By the watercourses of Reuben

There were great resolves of heart."

Plainly enough, this entire analysis proceeds from an intellectual reaction upon ordinary experience. Principles of division are involved, and therefore the operation of more or less extensive knowledge, based on observation, attention, and reflexion. Even the fragmentary vicws of current small-talk presuppose no less. Now, as Darwin said, "no one can be a good observer, unless he is an active theorizer." 1 In other words, facts and circumstances

${ }^{1}$ Life and Letters, vol. i, p. 126. 
fail to reveal their true significance - or any significance, for that matter - till arrangement overtakes them. They demand a setting. A main vice of popular thought issues from the tendency to suppose that interpretations illuminating on one level of experience suffice equally for any. Nay, one may go so far as to declare that many difficulties vexatious to Christians now, whether pro or con some fundamental questions so called, originate in just this loose procedure. When subjected to criticism, they disappear or assume an altered aspect. Consequences of mental refraction, their relation to religion turns out more or less dubious.

"We live in deeds, not years; in thoughts, not breaths; In feelings, not in figures on a dial.

We should count time by heart-throbs. He most lives Who thinks most, feels the noblest, acts the best."

At the risk of intruding dull or difficult matters, let me try to illustrate the situation. The plan may serve to clear our minds of cant.

Although the universe as a whole forms a single unity, differentiation fills out our fleeting moments. Man, for example, can be viewed as a machine or as a 'living soul,' or as any one of a dozen things intermediate between these extremes. But it is plain that the mechanical factor functions in a subordinate 
fashion when we emphasize the 'living soul' aspect. While present necessarily, it does not determine exclusively the treatment of the problem. And this familiar subordination of some differences appears characteristically when the constructions of knowledge come in question. The thinker or observer never sidles up to objects in a merely receptive frame of mind. The ideas he employs, even in abstract processes, contain principles of direction; the analysis, that is, proceeds with reference to an end, and struggle as he may, contributes to the end, moulds it accordingly. The method of approach cannot but be normative. A pure external relation of subject to object is pure nonsense. Even in theory we cannot view the two as if they stood side by side like bits of china on a shelf, because they never so present themselves in fact. A transitive process operates invariably from the side of mind. The simplest way to realize this is to take examples. One instance from each of the four 'universes' noted above may suffice. To avoid the easy objection, that I am preparing the ground, I have chosen quite at random, and have allowed others to speak purposely.

(a) The 'universe' of things. "When a railway carriage is running on a straight piece of road, we 
become unconscious of the motion unless we look at external bodies; but we detect at once any sudden change of speed. If the motion of the train be checked by a sudden application of the brake, their inertia (which really maintains their motion) appears to urge the passengers forwards. A sudden starting of the train produces the opposite effect. While the steady motion continues, a conjurer can keep a number of balls in the air just as easily as if the carriage were at rest. But these things need not surprise us. Our rooms are always like perfect railway carriages in respect of their absolutely smooth, but very rapid, motion round the earth's axis. The whole earth itself is flying in its orbit at the rate of a million and a half miles per day; yet we should have known nothing of this motion had our globe been perpetually clouded over like Jupiter. The whole solar system is travelling with great speed among the fixed stars, but we know of the fact only from the minutely accurate observations of astronomers, aided by all the resources of the Theory of Probabilities." 1

Here we have what logicians call crucial instances. But, evidently, the crux, or sign-post, is dictated, as it were, by the intellectual attitude of the observer.

${ }^{1}$ Properties of Matter, P. G. Tait, pp. 95-96 (2d ed.). 
Tait proceeded on the doctrine of inertia laid down in Newton's first Law of Motion. This, once more, lies embedded in Newton's third Definition of Force. "The vis incrtice of matter is a power of resisting, by which every body, so far as in it lies, perseveres in its state of rest or of uniform motion in a straight line." Now, all these propositions are controlled by mental refraction. They represent abstractions from experience, possible only to a being endowed as man is. Within the sphere of things they apply perfectly, nay, can be made the basis of further interpretation. Professor Mach, for instance, would combine Newton's Definition and Law in a fresh and, as he conceives, more concrete statement. "Bodies set opposite each other induce in each other, under certain circumstances to be specified by experimental physics, contrary accolerations in the direction of their line of junction." 1 Excellent, I suppose, in the realm of experimental physics, but what meaning has it when carried over into the fields of morals or religion? The clew serves within the definite range of experience whence it came. In the psychological maze it leads nowhere.

(b) The 'universe' of living things. Here we may avail ourselves of a case stated by Mr. Alfred

${ }^{1}$ The Science of Mechanics, p. 243 (Eng. trans., 2d ed.). 
Russel Wallace. It offers an admirable illustration of the inevitable tendency of theory to suggest reliable meaning, to hint the end in the means.

"Among the numerous applications of the Darwinian theory in the interpretation of the complex phenomena presented by the organic world, none have been more successful, or are more interesting, than those which deal with the colours of animals and plants. To the older school of naturalists colour was a trivial character, eminently unstable and untrustworthy in the determination of species; and it appears to have, in most cases, no use or meaning to the objects which displayed it... But the researches of Mr. Darwin totally changed our point of view in this matter. He showed clearly that some of the colours of animals are useful, some hurtful to them. ... That the colours and markings of animals have been acquired under the fundamental law of utility, is indicated by a general fact which has received very little attention. As a rule, colour and marking are constant in each species of wild animal, while, in almost every domesticated animal, there arises great variability. We see this in our horses and cattle, our dogs and cats, our pigeons and poultry. Now, the essential difference between the conditions of life of domesticated and 
wild animals is, that the former are protected by man, while the latter have to protect themselves. The extreme variations in colour that immediately arise under domestication indicate a tendency to vary in this way, and the occasional occurrence of white or picbald, or other exceptionally coloured individuals of many species in a state of nature shows that this tendency exists there also; and, as these exceptionally coloured individuals rarely or never increase, there must be some constant power at work to keep it in check." 1

Just so. The active element here is the intellectual, for the simple reason that its predominance alone guarantees an explanatory synthesis. But the categories employed possess no more than analogical value in ethics, say, while in numerous aspects of experience they avail not at all. Suppose one were to employ them to explain the ecclesiastical colours proper to the seasons of the Christian year!

(c) The 'universe' of other selves. A common custom, more honoured in the breach than in the observance, according to Hamlet, may serve our purpose here.

"That one man should drink with another was regarded by our forefathers as a more sacred symbol

${ }^{1}$ Darwinism, pp. 187, 188-190 (London, 1889). 
of brotherhood even than the sitting at meat together. This belief was derived, in part, from the impression made by the stimulating effect of the wine, mead, etc., whose intoxicating properties have led to their choice by all peoples at all times for ceremonial purposes. In part, however, the idea of the inspiriting draught is associated with that of the blood, universally considered by primitive man to be the seat of the vital forces. He who drinks the blood of an enemy takes to himself the dead man's strength; he who exchanges a drop of blood with a friend becomes thereby his blood-relation, as if a son of the same mother. . . B But as the age grew milder, the symbolism of a draught from the same cup took the place of the original ceremony. . . Soon the draught of brotherhood extended its range beyond the individual; it became an emblem of the union of host and invited guests, the cup travelling from hand to hand at the common meal. So the symbol reduces, first of all, to a simple sign of friendship, and finally comes to be a mere expression of social attention. When the cup ceased to pass from mouth to mouth, and the greater luxury of the time gave each guest his own drinking glass, the common draught from the same bowl was indicated by the touching of glasses, and the draught of 
brotherhood between two comrades had degenerated into the modern toast." 1

But, plainly, apart from a point of view, suggestions of this sort would be impossible. In the time of Newton they never occurred to a thinker even of his genius, as his commonplaces on prophecy, that elicited Voltaire's sncer, serve to show. ${ }^{2}$ What point of view, then? Let Wundt reply himself.

"Every phase of our modern life is permeated with usages that have survived from long-forgotten cults. ... Among them, too, are many fossilized forms, the petrified remains of once living actions, which owe their preservation simply and solely to that vis inertice which is as characteristic of our ideas as it is of our material bodies. Now if we consider the bare results of these transformations, without reference to their historical past, we may easily be misled into looking for their explanation within the circle of our present experience, and substituting the aims which they do or might subserve to-day for the true causes of their origination. But

${ }^{1}$ Ethics, W. Wundt, vol. i, pp. I43-I44 (Eng. trans.).

${ }^{2}$ See his Observations upon the Prophecies of Holy Writ, particularly the Prophecies of Daniel and the A pocalypse of St. John (in vol. v of Isaaci Nextoni Opera qua exstant omnia (1779-1785); separately printed in 1733 and, with notes by P. Borthwick, in I $8_{3}$ I. The edition of 1733 may be procured still). 
in doing this we should be forgetting a law that is of the very highest importance in all mental, but especially in moral, development: the law that mankind is prepared for the adoption of new ends of life by modes of conduct already existent, but primarily adapted to other ends. ... The tendency of custom to live on in new forms after the decay of its original contents paves the way for the origination of the most varied purposes. And if, in the last resort, it is a moral development that secures the greatest advantages from this law of persistence in the midst of change, credit is not therefore to be given to the law, but only to the forces of which that moral development is the expression." 1

Here, once more, the theory lays down the lines of evaluation. And because it deals with the 'universe' of human psychology, its possible application in the sphere of religion becomes apparent on the face of it.

(d) The 'universe' of self. No man ever left a starker self-revelation than Marcus Aurelius. Let us listen to one of his naked confidences, meant for his own eye alone.

"You consist of three parts - body, breath, and mind. The first two are yours, to the extent of 1 Ethics, W. Wundt, vol. i, pp. I39-140. 
requiring your care: the third only is properly your own. Now if you separate from your true self your understanding - all that others do or say, all that you have yourself done or said, all that perturbs you for the future, all that belongs to your material shell or vital breath and lies outside your own control, all finally that sweeps past you in the swirl of circumstance, if thus exempting and clearing your mind-faculty from the play of destiny, you enable it to live free and unrestricted, doing what is just, willing what befalls, and saying what is true, - if, I say, you thus separate from your Inner Self the outer ties and attachments, the influences of time past and time to come, and so make yourself, in the language of Empedocles -

"A rounded sphere, poised in rotating rest;"

and train yourself to live in what alone is life - the present - then you will be able, for life's remainder and till death, to live on constant to the deity within, unperturbed, ingenuous, serene." 1

A modern would not put it thus, because his outlook involves a widely contrasted mental attitude, based upon many new presuppositions. The emperor's cross-examination of self was conducted in the light of later Stoic theory, and within the ethico-

1 Book xii, 3 (the translation is Rendall's). 
temperamental perspective peculiar to a Roman of the highest official class in that age. The value and importance of the facts could not but be rated by reference to this transitive rational standpoint. The tenour of the passage transcribed renders it unnecessary to explain why, with Marcus Aurelius, Stoicism had ceased to be a philosophy and had transformed itself into something hardly distinguishable from religious aspiration.

Again, the subtle and pervasive influence of man's inherited and acquired mental prepossessions continues ascendant among the most fearless and capable contemporary thinkers. Moreover, the fact that the vast majority remain quite unaware of its enormous directive power, indeed, often deny it angrily, serves but to confirm its sway. Nobody would suspect Huxley, for instance, of treachery to science, rather his devotion displayed itself in a temper almost fierce. Nevertheless, did he not say of mathematics, - the servant of all experimental science as of many biological and sociological investigations, - it "is that study that knows nothing of observation, nothing of induction, nothing of experiment, nothing of causation?" Perfectly true, no doubt; and yet, thanks to Huxley's very intellectual passion, how far his irony- 
"fails from truth by every stale-meant word Half-wantonly meeting the times' demand."

I should not have troubled you with these farflung illustrations unless I had intended them to hint a definite inference. It is this. The intellectual factor in our experience even of the commonest things exhibits instability. Nature--

"speaks

A various language"

as she passes from star-swirl to mountain-peak, from mite to man.

"Black spirits and white, Red spirits and grey,"

is poetry or gibberish, as you please, never empirical fact. But so is -

"Only the actions of the just

Smell sweet and blossom in the dust."

Thus, when we want to be perfectly clear intellectually, we discover at once that judgements luminous in some spheres produce darkness visible in others. Accordingly, we switch our mental currents, alternating from the useless or even baleful to the apposite, as the context demands. Now, what is thus true of individual experience in its several contemporaneous fields, holds also of genetic experience 
when regarded in the light of its history. For us to-day, the legend of the nymph Echo, who pined away for love of Narcissus, till she faded to a mere voice, excites incredulity or, mayhap, arouses laughter, - we feel inclined irresistibly to recall the famous smile of the Cheshire Cat! Our woods are haunted no longer by Dryads and Hamadryads; to ask us to order our lives as if this delectable companionship still obtained, were absurd. Similarly, the psychological perspective necessary for St. Francis's preaching to the birds, or for Luther's ink-pot lunge at the devil, has disappeared. In a word, we regard such fables from another angle. So, just as we cannot put a price on tears, or tell the colour of love, we fail to explain blighted harvests by cold winds sent from the interior of Jotunheim by the Hrimthurses; meteorology has altered all this. In face of ethics, and sociology, and economics, we no longer seek counsels of perfection from the Norns. And yet, transformed completely as these intellectual outlooks are, our spiritual thrust remains very much as it always was. With his customary penetration, Jesus expressed this in that memorable answer to the Pharisees, when they advised him to flee from Herod. "And he said unto them, Go and say to that fox, Behold, I cast out 
demons and perform cures to-day and to-morrow, and the third day I am perfected. Howbeit I must go on my way to-rlay and to-morrow and the day following: for it cannot be that a prophet perish out of Jerusalem." 1 Some experiences must needs be lived, knowledge cannot satisfy their passion. Others submit to logical constructions - causation, for instance. And the former, despite their elusive quality, seem to possess the power to bring us into contact with such changeless, stable states as our poor human nature prefigures. Intellectually, man has ever walked to-day, and to-morrow, and the day following; nevertheless, in the deepest things of his spirit, it cannot be that a prophet perish out of Jerusalem; if he perish there, men will appropriate his message preëminently.

But paradox supervenes here. Suppose we grant (although it makes no vital difference to the argument) that the insights of a Gotama or a Jesus are always embodied intellectually, by them as by their disciples. It would thus appear that the primary depends upon the secondary for its transmission or maintenance, and in relative degree becomes secondary itself. I am unable to rest in this view. The paradox seems capable of resolution. For, the con-

${ }^{1}$ Luke xiii. $3^{2-33}$. 
ceptual presentation of this, as of everything else, cannot but be called symbolic. And the root of numerous difficulties, as of endless religious controversy, lies embedded in the constant tendency to deal with the token as if it were the thing betokened. The two patch up peace continually on terms detrimental to the one or the other; consequently, they have waged, and wage now, an unbroken, stern struggle. As the intellect presses forward to sit in judgement, life shakes itself free and demands justification. "Woman, believe me, the hour cometh, when neither in this mountain, nor in Jerusalem, shall ye worship the Father." 1 In the profoundest sense, this hour never is, but always is to be. And why? Because religion involves elements that elude, not merely knowledge, but even the set purpose of the men who, at any given moment, happen to have formulated it. Or, in philosophical language, its ultimate character is dialectical. To wit; its constitutive process is of such texture that the intellect cannot dictate its truth, or force it to abide in dependence on this or the other precise scheme. As the intellect passes the religious material through its medium, a transformation occurs which inevitably starts further transformations from time to time. The quod

John iv. 2r. 
semper, quod ubique, ci quod ab omnibus, so far as it can be expressed propositionally, possesses, in the very nature of the case, a local habitation and a name. For, the tension of the complete manhood, so typical of religion, cannot be reproduced by any species of intellectual alcheny. The explicitness of logic, say, necessarily removes one from the 'universe ' of religion to a region that may turn out of a far different sort. In brief, as knowledge clarifies the religious consciousness, it fails proportionately to exhaust it. So, doubt, or at any rate enquiry, finds due opportunity. The slighted portions, as it were, reappear over and over again, with an imperative demand that intellect abate its toll. Moreover, this process consists in no appeal to sentiment, to feeling, or to some vague belief in vaguer eventualities, as many neurotic or credulous folk seem to suppose. Rather is it a reference to facts that admit of no trifling. The less must face a new triangulation of the greater, in order to correct its partial computations. For, clearly enough, the abstractions charmed by knowledge from life fall short of the actual fact. Even the most general, and therefore the most true, "law of nature' never applied, as formulated, in every observed case. How much more, then, the poet hits the truth, when he writes, - 
"I for an hour have grasp'd the great insight . . .

A system, self-containment which is beauty, The beauty that my creed hath wholly missed."

Thus, when we carry the question of 'universes,' with their evaluations and systematic prescriptions, into the traffic between knowledge and religion, we are bound to admit that the latter supplies the postulate. Of course, it is as impossible to separate religion from conscious research and reflexion regarding its nature as to talk of a spiritual reality out of all relation to the chemico-physical world of our habitation. Notwithstanding, as matter of soberest fact, this blind, mechanical, uniform earth does contain the aspirations and plans of humane beings. For us, morals, and art, and religion are live things at least as potent as heat, and chemical affinity, and cellular change. No one enjoys a monopoly of necessity more than any other. For, an isolated necessity, a necessity that fails to square with others incident to the same unity, were the purest moonshine. Accordingly, as intellectual judgements refract now this, now that aspect of our inconceivably complex life, readjustments become imperative, and such experiences as religion receive novel, often unexpected, interpretations, even although the fundamental 'stuff' remain identical. Remem- 
bering all this, I think we shall have laid hold upon a clew that may serve to solve the maze surrounding certain contemporary difficulties, even if, as we must recognize quite frankly, our human nature stands, as ever, -

\author{
"well-nigh vocal with \\ The insight of this tragedy of mute \\ Omnipotence."
}

Nor does the story cease here. As thinkers have shown often, men are mastered by an ineradicable tendency to express the 'spiritual' and psychological in terms of the 'material' and sensuous. In its elaboration upon life, knowledge at once syncopates and specifies by the use of images. The process serves to throw light upon our condition, because it exhibits, even when it neglects to emphasize, limitations bound up with our humanity. A cardinal example of this procedure happens to have occurred, and to have maintained itself more or less intact, midmost the very subject of these Lectures. The materialistic analogy from a geological specimen, or a river, or an animal species has been applied, and with amazing persistence, to 'Christian truth.' Search almost where you please (time and place appear to be indifferent), and you will find the problem of religion conceived as if the task were to trace the derivation 
of a fixed thing from a definite source. To attack the question thus, however, forecloses the result. The method only imports into the religious ' universe' ideas that, primarily, possess no application there, and, secondarily, raises false, even irrational, problems by vicious analogy. The popularity of the attitude, like its constant recurrence, furnish startling commentary on the dangers superinduced by interferences of intellectual abstraction. But, for this very reason, it may be viewed as perfectly natural and explicable. Interferences similar, say, to those of a microscope, our conceptual constructs must be tested and corrected, even altered or rcmoved, ere we reach a position to record the precise object before us. Aids to observation and reflexion they prove from time to time, without doubt; yet, plainly, they hold no patent rights in truth. And the major difficulty incident to investigation of religion centres precisely in man's habit of consecrating them as if they alone embodied ascertainable truth. But, just like 'laws of nature,' recognized openly as abstractions from experience, these religious judgements are doomed to change, and susceptible to purgation from extraneous or temporal admixture. Negative instances transform them. For example, the discoveries of Copernicus, Lyell, and Darwin, on the one hand, 
of Rawlinson, F. C. Baur, and Kuenen, on the other, have altered them profoundly in the course of a bricf history; while they have been purified, with happy frequency, by those miracles of concrete human life called saints. On both sides, you see, hard and fast system must submit to constant readjustment. Thus, most conspicuously, God has justified his ways to mankind. You may conceive redemption in mechanical, or juridical, or domestic terms; all prove to have been no more than pictorial representations. The problem abides unlaid, still capable of further illumination by other less inadequate statements. So, if it be true, as many tell us, that the collapse of dogmatic Christianity forms the most significant among contemporary movements, we need not lose our heads and give way to panic. Let us stress the adjective, remembering that, in the words of one of the most pious scholars of last century, "many a traditional idea which circulates amongst us seems credible only because we have never examined it." 1 Let us remind ourselves, too, that 'traditional ideas,' like present opinions, are no more than essays to prefigure religious truth more completely. For the truth of religion cannot be brought in question any more than the truth of nature, no matter how much

'Still Hours, Richard Rothe, p. 68 (Eng. trans.). 
or how often we may be led to revise our manner of formulating both to our meagre understandings.

Finally, the considerations just adduced seem to force the conclusion that, whatever religion may be, it is not a set system of formulated doctrine, or even an aggregate of clarified beliefs, especially beliefs in the existence of imaginary, or in the authority and power of dead, personages. I have referred to "the tension of the complete manhood.' ${ }^{\prime}$ By this I mean to suggest that while, probably, a satisfactory definition of religion is beyond reach, every attempt at definition presupposes a certain psychological state, - often termed 'spiritual,' - a state peculiar to human beings, so far as we can know. That is to say, we are confronted by a process in experience, offering the chief characteristics of other processes in self-consciousness. In all likelihood, examination would prove it excessively complex. Many coefficients would enter into its constitution; above all, it would be directed by some ideal or apperceptive evaluation which, in its turn, would show up endless subtleties. It would imply "the control of our activity as thinking beings by conditions which are fixed for us and not by us." 2 And it might be very

1 See above, p. $3^{\text {I. }}$

${ }^{2}$ Analytic Psychology, G. F. Stout, vol. ii, p. 239. 
prone to involve the fallacy, universal among savages, common even among civilized folk, our neighbours, of mistaking subjective for objective necessity. Be all this as it may, the psychological situation in the process of experience, tense enough to rise to the levels of religion, certainly absorbs into itself those main factors of the inner life linown generally as Intellect, Desire, and Will. Thus, as I have tried to indicate, the expression by intellect alone falls short of the jubilant reality, and unavoidably so. Reason sceks order, completion, unity. But the spirit-life swoops on, carrying intellect with it, and exacting original perspectives for original conclusions. Thus any effort after apotheosis of a single stage spells failure. Sufficient with incomparable sufficiency as the 'beautiful moment' may be, its very perfection breeds defect, the instant its day of due reckoning passes.

"... the thoughts of men are widened with the process of the suns."

The central and dominating fact in religion is its imperious call for a new way of life; and this seeks freedom as its indispensable condition. Yet, when man comes to think of such matters, the central and dominating fact is the imperious call for cut-anddried system, for something 'to go by'; and this 
seeks bondage as its indispensable condition. They have never been coördinate, never can be. On the other hand, let the intellect fall as short as it may or must, it is enlisted invariably, as if in veriest despite. The new creature cannot escape self-caricature. So, if the heretic of to-day miss beatification to-morrow, the golden words that hush mankind might often fall upon silence. Every generation must bear the burden of this lesson after its fashion. The human soul chains itself at each successive sunset, and, with the glow of the next dawn, would fain strike off the shackles. But, enamoured of its evening artistry, doubts and tears, angry passions and ugly words beset it, as it rouses anon to the sense of an undone task, and fondles the forms it would fain break to be rid of impediments. Past satisfactions indeed rest satisfactions; notwithstanding, unprecedented sights so move, and prophetic promptings so pulsate that the throb of joy becomes the measure of unplumbed sadness. The ideal, as stated, as something to be maintained stoutly, baulks the ideal that beckons to distant and untried ends. Our tragedy - and our salvation - pivot on a religion that professes to come complete from a past dead and done with; yet this religion is, or continues in vitality, only because quickened by the 
perennial inspiration of the blood-tinctured present. By a law of our innermost nature, then, we are condemned to pass through the valley of negation ere we win any Pisgah-sight atop the mount of transfigured and transfiguring faith.

"For we are Ancients of the earth, And in the morning of the times.

So slecping, so aroused from sleep Thro' sunny decades new and strange, Or gay quinquenniads would we reap The flower and quintessence of change ... The prelude to some brighter world."

In the three subsequent Lectures I shall attempt to summarize the two intellectual achievements of the past century that are responsible for most of our present disquiet and unrest in religion; the hazards of belief congregate here for us. As I follow this difficult track, you must do me the favour to bear in mind certain things. First, I shall be compelled to deal with researches in which I have borne no part. They lie as open to you as to me, we are equally in the hands of their master-builders. In other words, I shall speak, not as an authority, but as any educated man might. Second, timelimits require that discussions of pros and cons disappear; these you can find in literature accessible to everybody. Third, I fear many fail to realize 
40 MODERN THOUGHT AND THE CRISIS IN BELIEF just what is fast becoming commonplace among competent scholars; and so I am bound to arrange the material in such a way that its cumulative effect may strike straight home. This, indeed, will condition the problem to which $I$ shall invite your attention in the four concluding Lectures. 


\section{LECTURE II}

\section{THE WATERS OF MERIBAH}

While, as we have seen, religion eludes definition, its character cannot be compassed in a series of words, a very general description may not transgress the bounds of prudence. Religion is a state induced in self-consciousness by man's sense of his own insignificance and imperfection, as contrasted with the high vocation revealed to him by his ardent, if froward, ideals. Incarnate only in human flesh, this psychological condition encrgizes two ways. On the one hand, it compels an accounting from the physical world, or seeks reply from Nature to all sorts of questions about which, fundamentally, Nature must remain utterly dumb. Sweep the mighty visibilities of the heavens with the telescope, the minute invisibilities of the earth with the microscope, intensify both range and power of observation as you will, you are thrust back, to say, 'Behold, it is not there!' The Sphinx is ever with us, for, on the Whence, the Why, the Whither, this frame of 
things, as our immediate perceptions disclose it, has scarce a hint to offer. On the other hand, the religious consciousness composes an interpretation of 'spiritual' life, and would force the very gates of heaven to assuage its yearning. But, in proceeding thus, it quits the region of sober knowledge, and acquires what no pure scientia ever pretended to supply, - a constructive estimate of the relative values to be put upon events possible and probable nowhere outside the mystic regions of the soul. According as the tension of the religious process is, so will the satisfactions peculiar to this evaluation be. Here solutions abound in plenty; but they descend from their father, the heavenly vision, and betray everywhere unmistakable traces of their lineage, - an origin in ideal possibility, not in mundane attainment.

"The night is come, and all the world is still. Men say it is a time for sleep and dreams; But now she throws no pall upon the space That spreads above me. ...

\section{Meseems}

This is the hour for man to bend the knee Of the full soul to the Divinity."

Now, even if the ideal truth of religion be thus admitted, it were lamentable to forget that the 
haltingr embodiment issues on earth. An intellect manifested in its own refracting forms and processes, emotions accompanied by the somatic states characteristic of an animal, albeit the most complex animal, and a will, foiled continually by circumstances that are none of its creation, impose terms present in every statement. Thus, as these psychological factors, in unison or conflict, happen to envisage experience at any given time, so the special activities of consciousness, typical of religion, express themselves. Accordingly, difficulties and doubts, changes and transformations occur, often cozening the human spirit, and yet bearing witness to its kaleidoscopic limits, as it struggles to liberate its dearest aspirations.

These matters must now claim attention at some length. There never was a crisis when they demanded more candour and plain speaking, or sincerer discussion of grave questions, especially before an audience composed, for the larger part, of those who, from day to day, are forced into contact with information, ascertained or in process of consolidation, that traverses some past presentations of 'Christian truth,' rich in sacred association to many, not least to myself. Nevertheless, nobody need fear facts; all ought to fear suppositions and $e x$ 
parte pleas, particularly with regard to subjects of the last importance for a sane view of the deep that calls unto deep in our common humanity. Afraid 'to face the music' of all that has become incorporated in the treasure of knowledge, religion shrivels easily to superstition. It were surely most perilous that, confronted with man's profoundest needs, we should rest satisfied with unevidenced affirmations, or worse, with opinions erroneous obviously to everyone who is free to judge. At this good hour, religion suffers violence far more through misbelief than through scepticism; nobody mocks Christianity, thousands jest over the thaumaturgy wherewith too many confuse it. Would, indeed, that we might pass the cup of these waters of bitterness! But that is impossible - impossible even were the conclusion forced irrevocably to those hopeless terms; "philosophy having become a meditation, not merely of death, but of annihilation, the precept know thyself has become transformed into the terrific oracle to Edipus -

" "Mayest thou ne'er know the truth of what thou art." "1

The scene of proof - and of strife - lies athwart the strait way to the valley of blessing. Like Job,

'A Candid Examination of Theism, by 'Physicus' (G. J. Romanes), p. II4 (3d ed.). 
we answer the Lord, and say, "Hear, I beseech thee, and I will speak; I will demand of thee, and declare thou unto me." 1 We tempt the Father of Lights, and in all reverence, because He has left us without other choice, contemporary knowledge being as truly a divine revelation as ancient faith. "And he called the name of the place Massah, and Meribah, because of the striving of the children of Israel, and because they tempted the Lord, saying, Is the Lord among us or not?" 2

It will save misunderstanding, and serve to eliminate qualifications like 'perhaps,' 'but,' 'I think,' and so forth, if I state at the outset that my aim is to delineate the perspective, still unfamiliar to a considerable section of the lay public, resultant upon the entire trend of enquiry in the nineteenth century, and to envisage the attendant difficulties without any shirking. In other words, the main tendency of science and scholarship in our age, in its full rigour and vigour, rather than this or that restricted set of conclusions, will pass before us. This is no place to exhibit the apparatus in detail, and I must reserve particulars for another occasion. You will understand, therefore, that I am not necessarily in accord with every inference; I desire only to state the case

${ }^{1} J o b$ xlii. 4.

2 Exodus xvii. 7 . 
in such terms that none can mistake its meaning. If we are caught in a veritable sea of troubles, we must know at least what dangers threaten.

Unconscious of the strong synthetic and suggestive pressure exerted by the prevalent outlook of an epoch, we, even the students among us, tend to forget that we gaze upon a recent universe, one concealed largely, if not completely, a brief century since. Cast the mind's eye back to the era of the Declaration of Independence, or of that mightier cataclysm, the French Revolution, and what close grip upon men, organisms, and things do we find? Less than might be supposed. A mathematical conspectus of the mechanical relations subsisting between the molar masses of the solar system, extended by analogy to a few farther stars, formed the sum-total, to all intents and purposes. Of the physical state and chemical constitution of these units next to nothing had been ascertained intimately. Contrariwise, misconceptions or random guesses abounded in the realms of chemistry, natural history, and physiology; astounding superstitions concerning humanity in its most typical achievements - religion, art, morals, and society; nigh total ignorance about a possible coherent interpretation of history. Accordingly, we must recall that, since the dis- 
tinguished victim of the French Rerolution, Lavoisier, dethroned phlogiston, the physical sciences astronomy, physics, geology, and chemistry - have undergone extensive transformation. Since Bell noted the difference between the afferent and efferent nerves, the biological sciences have come to birth, and accurate conclusions from controlled obscrvation have replaced conjectures bred of mere suspicion. Since Hegel enunciated the epoch-making principle, that human experience explains its own development, and that, otherwise, it is irrational, whole series of human sciences have been elaborated. Thus, no matter where we pry, we contemplate a universe unsuspected by our forefathers, and command numerous principles hidden quite from them. Literally, a new heavens, a new earth, and a new 'all that therein is' salute us. Moreover, whether we be astronomers or physicists, chemists or physiologists, biologists or psychologists, historians or philologists, anthropologists or philosophers, we envisage our several topics from a standpoint identical in essentials for everyone. Indeed, so far has this unitary movement proceeded that, for each, as concerns his special investigations, another view were well-nigh inconceivable. Yet, when Dalton was excogitating his atomic theory, just one hun- 
dred years ago, this same view found no application outside 'celestial mechanics,' and, even there, room remained for contradictory possibilities, as was evidenced by Newton's naïve idea, inherited by Paley's egregious philosophy, that a Being uncommonly familiar with the laws of geometry had injected gravitation and inertia into the heavenly bodies. This compelling apposition, between the contemporary outlook and that regnant till about the middle of last century, may be brought to a sharp point in the statement that, for the former, the universe is one, for the latter it always was $t w o$. To us, the universal processes energizing everywhere supply the primary well-springs of explanation; to our predecessors, an otiose reference to a somewhat, neither mind nor matter (or, as we would say, neither consciousness nor energy), to a somewhat, therefore, unknowable ex hypothesi, provided an extra-mundane mystery whereto nearer mysteries might be traced back. And the more subtle the problems on hand, the more intricate and elusive their factors, the more besetting the presence of this tenuous, pervasive makeshift. To illustrate: 'celestial mechanics' almost excluded it, but in chemistry, biology, psychology, literature and language, morals and religion, in an expanding series, opportunity 
offered for the vagaries of supranatural interference.

How potently this metaphrastic phantasy ruled may be seen vividly from a cursory acquaintance with the marvels supposed popularly to offer adequate guarantee of authority in morals, of the authenticity of the human mind, and of the truth of religion. Take the last, for example; what a mournful record appears! The Ptolemaic astronomy, distorted by geocentric myopia, was made the cornerstone of Christianity. The divine inspiration of the Hebrew points was held essential to the preservation of orthodox faith. It was contended that, apart from literal foretelling by Old Testament prophecy, the New Testament could not be vindicated. It was asserted, by no less a person than Wesley, if memory serve me rightly, that the inviolability of the Christian faith is bound up with a belief in witchcraft. It was imagined commonly that man's hope of eternal salvation reposed on the historical accuracy of the creation myth in Genesis, and that the certainty of this expectation found strong credentials in the fable of Lot's wife and in the tale of Jonah's incarceration in the whale. It was actually alleged, with perfect sobriety, that the discovery that the world and man were created by 
the Trinity on October 23 d, 4004 B.c., at nine o'clock in the morning, had essential bearing on the spiritual life. It was asked, cynically, "Who will venture to place the authority of Copernicus above that of the Holy Spirit?" Geology suffered judgement as "an awful invasion of the testimony of revelation." It was maintained, as an important scientific fact, that because "death entered the world by sin," there was no death on earth prior to Eve's fault. It was insisted that "of all instruments of God's vengeance the thunderbolt is the chief." Study of physics, as of medicine and chemistry, was interdicted by ecclesiastical order "on account of certain suspicious novelties." The bones of a goat, supposititiously those of St. Rosalia, were employed as fetiches to heal disease, on the obvious ground that "bodily infirmity frequently results from sin." Lunacy and hysteria were attributed to the machinations of Satan, and treated accordingly. It was stated gravely that the Almighty spoke Hebrew, and that every language originated from this one at Babel. Numbers taught that the Pentateuch was dictated to Moses by the Deity about I 520 B.c., and affirmed that any other view must be stigmatized as "a mass of impieties, a bulwark of irreligion." The probable historical interpretation of the famous 
Immanuel passage in "Isaiah" was dismissed as "horrible, false, perverse, and destructive." On the contrary, every scientific statement in the Bible was described as "infallibly accurate; all its histories and narrations of every kind are without any inaccuracy, its words and phrases have a grammatical and philological accuracy such as is possessed by no human composition."' Baseless dogmas and childish errors of a similar kind might be adduced practically without limit; and, strange to say, all alike - monstrous, absurd, or merely silly - have been put forward as foundations or essential portions of 'Christian truth.' As a matter of fact, so far from having aught to do with 'Christian truth,' all issued from the preconceived view of the universe as two, the Irish-bull conception of ultimacy, now abandoned by investigators.

According to current conceptions, the universe ebbs and flows in a single, vast order - of a second order, incommensurable with this, we know nothing. It presents itself as a 'closed whole,' explicable from within on its own terms, never as a broken system controlled from without by some bruited, but absentee, designer. Such is the conclusion to which

1 See, for very full details, A History of the Warfare between Science and Theology in Christendom, Andrew D. White. The weak point of the book is Dr. White's rather jejune notion of theology. 
we have been, and are being, driven on all sides by serried testimony pouring in overwhelmingly from every scrutiny undertaken by special investigation. Obviously enough, it imports, not simply a change, but a complete revision of the ideas we can entertain about religion as, indeed, about anything. No doubt, a smooth agreement concerning the ways taken by the process has not eventuated, cannot eventuate, probably, for years to come. But consensus about the basal fact tends to become more and more unified. In other words, differ as we may and do over the means operative in the cosmos, less and less divergence exists about the attitude to be adopted towards the universal order. Whatever conclusions may emerge in a future we wot not of, certain it is that all who hold convictions respecting the immense importance of religion must face the altered situation - and the sooner the better. The churches, particularly if the laity will rouse and assert themselves, stand in the shadow of an unexampled problem, as of a unique opportunity. Signs of the times, so clear that he who runs may read, indicate a direct, strenuous demand upon them. It amounts to no less than this - that they bring Christianity down from the clouds of outworn supposition to tabernacle in the common places of our 
sore puzzled workaday life. The religion of unrestricted, spontancous access to God can hardly retain its propulsive leadership under the handicap of petrific formulie alien from the most earnest insight of the day, and permeated with imagery too often crass in its reminiscent paganism.

"And not by eastern windows only,

When daylight comes, comes in the light,

In front the sun climbs slow, how slowly,

But westward, look, the land is bright."

Beyond question, many cherish the conviction that scientific advance has bereft life of worth and hope. On the contrary, it is equally clear that numbers raise a joyous pæan to the victory of 'reason' over 'superstition.' In proceeding to attempt a delineation of the case, I shall not forget either extreme. But the root of bitterness will have precedence.

For the sake of convenience and brevity, it may be well to adopt the objective classification of modern knowledge. The 'universes' of 'things' and of 'living things' group themselves under the title 'science,' in the narrow sense accepted conventionally. So, too, the 'universes' of 'self' and of 'other selves' fall together. But this unity exhibits two aspects. On the one side, it regards man as he has been and is; 
from another it contemplates him as he ought to live, or as he might become. Thus the field of knowledge so distributes itself that we are bidden review the situation, first, as 'science' sees it; second, as it appears from the standpoint of historicocritical research; third, as it flashes forth in the ideal spheres of morals and religion. Yet, even accepting this tripartite division, we must recall that, in every instance, the unconquerable duality of human nature - as physical and self-conscious - produces disturbance and, by consequence, sets problems of the utmost intricacy, generates fertile misconceptions.

\section{The Scientific Consciousness}

It should be noted at once that the tremulous essays of the early masters - Hipparchus, for example - and the refined experiments of a Rutherford and a Ramsay, of a McMurrich and a Morgan, exhibit no difference in spirit. The contrast happens to be one of sweep - of the material wherein scientific method can work victoriously. So, at the outset, let us take stock of this common spirit.

No recondite observation were necessary to prove that, in average affairs, the characters of our friends tend to differ. Putting the matter very synoptically, 
one may affirm that now this, now that, element in the psychological organization dominates an individual. We all know the person whom emotion or, as often, sentiment masters; similarly, some betray the primacy of intellect, others of will. Roughly, these contrasts of psychological expression correspond to divergent types of reaction upon the most ordinary events. Social institutions intimate as much. All members do not subserve the same offices, as an influential writer saw years ago. "And God hath set some in the church, first apostles, secondly prophets, thirdly teachers, then powers, then gifts of healings, helps, governments, divers kinds of tongues." 1 Plainly, the asthetic or emotional, the utilitarian or practical, and the critical or reflective temperaments are ever with us, each ministering in virtue of its special gifts. The last has made the nineteenth century peculiarly its own, and, for three generations, has contrived to set its seal upon the prevalent trend of the age. As its self-set task would lead one to expect, its habitual spirit presents little, if any, mystery. Confronted with the tortuous operations of nature, the scientific consciousness scents order throughout, and strives to sublimate its consequent inferences into baldest simplicity. The

$$
1 \text { I Corinthians xii. } 28 .
$$


laws of motion, the kinetic theory of gases, the law of the tides, the theorems of the conservation of energy and of evolution are reductions of phenomenal flurry to very plain routine. Consequences of long, intimate, and most ascetic devotion, their history exhibits the attitude necessary to scientific achievemeni. Thus certain qualities evince their unabashed presence invariably. To wit: in the first place, scrupulous care and unprecedented accuracy. Nothing is too unimportant to be overlooked; no trouble counts for hardship, so long as review and confirmation continue desiderata; above all, the uttermost loyalty to fact rules supreme. Secondly, on the basis of these qualities a certain confidence supervenes, and receives justification from the gradual rise of a solid masonry of knowledge. Small wonder! For, no matter what one's predilections or prejudices, no matter what one's hopes, or fears, or desires, conclusions drive home with sublime disregard. In the scientific kingdom nought happens according to man's wish or will; everything issues from a dry, intellectual recognition that thus, and thus alone, the unheeding phenomena take their changeless way. Third, as a natural sequel, the new coördinations collide with otiose supposition and unexamined belief. The stimulus of conflict is generated, fresh material 
forces itself within the scope of research, and the scientific mind presses on to wider inferences. But transformation involves destruction, and the very process vitalizes once more many affairs left for dead or foreclosed. This movement, fourthly, leads to formulations of hypotheses - everything cannot be settled in a moment; while hypotheses demand fresh observations, original experiments, and more circumspect reflexion. Accordingly, the scientific spirit displays its transitive qualities in two main directions. On the one side, by insistence upon the need for a definite knowledge purged of mystery and snap-shot opinion, it warns the human mind against impracticable adventures. On the other, by its total disregard of fetters forged by supposition in the 'ages of faith,' it liberates mankind, and urges to the analysis of experience in its every cranny. Baseless authority thus goes by the board, and all restrictions, confining inquiry to ruts where 'peradventures' and prohibitions prevail, vanish away. Nothing is to be interdicted; nothing can be too unexpected or unpalatable, provided it present itself panoplied with evidence. In a free atmosphere a rigid methodism builds out its bridge, with elaborate precaution, over the chasm of the unknown. 
Consequently, as the scientific spirit sees, its mission is never to conform the cosmos to a logical, much less to a theological, scheme, but to describe verifiable connexions, and to recount how these connexions are maintained as a matter of simple observation under conditions that preclude subjective disturbance. As Spencer said, in one of his earliest essays:-

"Considered genealogically, the received theory respecting the creation of the Solar System is unmistakably of low origin. You may clearly trace it back to primitive mythologies. Its remotest ancestor is the doctrine that the celestial bodies are personages who originally lived on the Earth - a doctrine still held by some of the negroes Livingstone visited. Science having divested the sun and planets of their divine personalities, this old idea was succeeded by the idea which even Kepler entertained, that the planets are guided in their courses by presiding spirits: no longer themselves gods, they are still severally kept in their orbits by gods. And when gravitation came to dispense with these celestial steersmen, there was begotten a belief, less gross than its parent, but partaking of the same essential nature, that the planets were originally launched into their orbits from the Creator's hand. 
... While the genesis of the Solar System, and of countless other systems like it, is thus rendered comprchensible, the ultimate mystery continues as great as ever. The problem of existence is not solved: it is simply remored further back. The Nebular Hypothesis throws no light on the origin of diffused matter; and diffused matter as much needs accounting for as concrete matter. The genesis of an atom is not easier to conceive than the genesis of a planet. Nay, indeed, so far from making the Universe a less mystery than before, it makes it a greater mystery. Creation by manufacture is a much lower thing than creation by evolution. A man can put together a machine; but he cannot make a machine develop itself. . . . That our harmonious universe once existed potentially as formless diffused matter, and has slowly grown into its present organized state, is a far more astonishing fact than would have been its formation after the artificial method vulgarly supposed." 1

Free, with complete freedom, to inquire into anything, man is as completely bound - bound to abide by discernible testimony. Of such is the spirit of science.

1 "The Nebular Hypothesis," Westminster Review", July, 1858; see Essays: Scientific, Political, and Speculative, pp. I, 55-56. (London, I863.) 
What, now, of method? Like every method, that of science operates negatively no less than positively. Its exclusions signify not a little. Darwin has presented this point with characteristic frankness.

"By collecting all facts which bore in any way on the variation of animals and plants under domestication and nature, some light might perhaps be thrown on the whole subject. My first note-book was opened in July, I837. I worked on true Baconian principles, and, without any theory collected facts on a wholesale scale, more especially with respect to domesticated productions.... When I see the list of books of all kinds which I read and abstracted, including whole series of Journals and Transactions, I am surprised at my own industry. I soon perceived that selection was the keystone of man's success in making useful races of animals and plants. But how selection could be applied to organisms living in a state of nature remained for some time a mystery to me." 1

The initial requirement of scientific method might be summed in the phrase, self-extrusion. To discover what the object is, apart entirely from faintest hint about what it might be, or from what expecta-

${ }^{1}$ Life and Letters, vol. i, p. 83; the italics are mine. 
tion might make it - this is a law of the Medes and Persians. "Nothing happens, it comes." So the questions, What comes? How does it come? How is it maintained in this way rather than that? reach no unclouded solution unless the observer so contrives as to eliminate admixture of self. The independence of the natural order forms a necessary postulate. Hence - and here lies the significance of the intimation - the scheme of things must be taken on its own recognizances. What you may think of it, apart from, or in addition to, its selfordained march, counts not a whit. This becomes very obvious in the region of experiment. Little as the layman may appreciate the fact, the great diffculty of the experimenter is, not to plan experiments, but to bring them under such thorough control that he can dissolve them into their simplest concomitant elements. For, while experiment spells interference, primary analysis implies that the factors work thus and so without human interposition. Science, that is, enforces continual self-criticism as the prime requisite of a reliable method.

Having insured this negative virtue, positive procedure is in order. Everybody knows that scientific research circles round observation. But observation means many things. For instance, it 
reckons with first-hand knowledge only. I have seen such and such, I have noted this and the other, or, as a vivid colloquialism puts it, 'I have been there.' What artists call atmosphere must have been evaporated. In satisfactory observations the objects must stand out clear-cut and raw - precise, unmistakable results alone avail. No provision can be allowed for 'almosts' and 'possibles.' If doubtful matters emerge, and especially if they persist, the aid of colleagues must be invoked, so that personal equation may disappear. Here we light upon another characteristic. Certainty rests on the rock of caution. Professions of ignorance, recognition that, for the present, even bare facts stay sub judice, form constant accompaniments of eventual success. And this means, further, that the real investigator loves no phenomenon more than another. Before the tribunal of the ascertainable all facts have permission to tell their own tale in their own way. Science discourages attempts to put a premium upon selection of evidence to bolster any conclusion, however desirable. It were almost superfluous to add that, when we pass from mere observation to that intensified species of observation known as experiment, the greater instability of the conditions calls for superlative exercise of the pre- 
cautions just enumerated. The laboratory has replaced Nature to a large extent, but only because it offers a short-cut to Nature. It enables us to save time, we need not wait for the lcisurcly dame to act. It places us in position to repeat phenomena indefinitely, and it puts within reach very accurate estimates of coöpcrant circumstances. Again, apparatus does not exist for the purpose of constructing expcriments, as the layman supposes often. On the contrary, it is nothing but a means for the extension of our senses, as by the scismograph; for immense increase in their delicacy of discrimination, as by the microscope; or it enables them to affect us in strange ways, as by the pseudoscope; or it insures an accuracy unobtainable otherwise, as by instruments for automatic registration. Moreover, laboratory methods and equipment help us to isolate and examine special constituents of a process, to plot the factors of a phenomenon, as it were, and thus to obtain mastery, piecemeal, over its ramified detail. In total effect, then, experiment originates schemes for overcoming and combating human limitations, physical and psychological. But its veritable revelations are received under the same stringent tests that rule direct contact with Nature, nay, under conditions even more stringent, because amenable to the forethought of control. 
The facts garnered under these safeguards, interpretation follows. Here we unveil another procedure, one of analysis and classification principally. As before, the phenomena dictate. That is, the assembled data raise difficulties of identity, similarity, difference, and contrariety; and the crucial measures of combination into groups demand attention. These hazardous excursions through the accumulated records serve often to disclose discrepancies, or even to evoke factors which had escaped previous notice. To scientific method even the slightest divergence acts as a danger-signal. The cry is, 'Back to the facts,' or the query is raised, 'What strange thing are they telling us now about themselves?' More than likely, the situation will call for a minute analysis. It may be necessary to proceed from the complex, supposed simple, to the simpler still, in order to find how disturbance originates, what it betokens. This regress, like the difficulty of dissolving experiments, constitutes one of the most exacting practical problems that scientific method has to face. But, difficulty or no difficulty, the old fidelity to fact, the precision, the caution, are to be maintained only with sterner rigour.

By consistent use of this method, the scientific 
consciousness reaches definite results. The common phrase 'natural law' labels one kind of inference; the less familiar, and often misunderstood, term 'hypothesis' proclaims another. At present, scientific inquirers disagree about the nature of 'law,' more particularly with regard to objective necessity or validity, and I cannot enter upon the grounds of quarrel here. Suffice it to say, they involve a very intricate problem beyond the competence of science, and that two views, the 'materialistic' or 'realist,' and the 'agnostic,' receive support. The older contention appears plainly in the following statement:-

"A Force is a Power which initiates or accelerates aggregative motion, while it resists or retards separative motion, in two or more particles of ponderable matter (and possibly also of the ethereal medium).

"All particles possess the Power of attracting one another - in other words, of setting up mutually aggregative motion - unless prevented by some other Power of an opposite nature. Thus a body suspended freely in the air is attracted towards the earth by the Force (or aggregative Power) known as Gravitation. A piece of sugar, held close over a cup of tea, attracts into itself the water of the teacup, by the Force (or aggregative Power) known as Capillarity. A spoon left in tea grounds or a foot planted on the moist sand similarly attracts the 
neighbouring drops. A piece of iron or coal exposed to free oxygen (each at a certain fixed temperature) attracts the particles of oxygen by the Force known as Chemical Affinity. In every case there must be an absence of counteracting Energies (or separative Powers) sufficient to prevent the union of the particles:... every particle attracts every other particle in some one of various ways, unless prevented by other Powers." 1

Evidently, Allen laboured under the impression that 'law' existed in an external world, and therefore that it could or did lead man into the precincts of essential reality. That is, natural law might be viewed as a 'thing' governing other 'things' and, by consequence, as offering a key to the constitution of being. On this interpretation, nature and mechanism become convertible terms, for we know causes in substantial existence. On the contrary, many contemporary leaders affirm that a 'natural law' cannot count for more than a symbol.

"A natural law, therefore, is not implied in the conformity of the behaviour of the energies, but this conformity is rather conditioned by the uniformity of our modes of conception and is also partly a matter of good fortune." 2

${ }^{1}$ Force and Energy, a Theory of Dynamics, Grant Allen, pp. 5-6.

${ }^{2}$ Popular Scientific Lectures, Ernst Mach, p. I 75 (Eng. trans., Chicago, I895). 
"All principles single out, more or less arbitrarily, now this aspect, now that aspect, of the same facts, and contain an abstract summarized rule for the refigurement of the facts in thought. . . Cause and effect, therefore, are things of thought, having an economical office.... In nature there is no law of refraction, only different cases of refraction. The law of refraction is a concise compendious rule, devised by us for the mental reconstruction of a fact, and only for its reconstruction in part, that is, on its geometrical side." 1

Summarily put, these positions imply that we provide 'laws of nature' by formulating uniformities of sense-perception. No 'law' is poised 'out there.' Our 'awareness' is solely of successions and coexistences of relations in a universal motion. If we agree, as we may easily, that science furnishes no ground-plan of the foundations of knowledge, but gifts simply a procedure for the dispersion of ignorance, we shall have mediated between the two views to some extent. For, after all, a law, as understood in both, amounts to a generalized statement of observed uniformities, nothing more. And, as the actual observations fall short of totality, in the nature of the case the conclusion imposes probability

${ }^{1}$ The Science of Mechanics, Ernst Mach, pp. $83-84,485-486$ (Eng. trans., 2d ed.). 
in various degrees. The instant we travel beyond this record, we quit the region of scientific stability.

Again, hypotheses must be described as reflective extensions of ascertained fact. ${ }^{1}$ A hypothesis forms the antecedent of any judgement which hangs upon an 'if.' 'The consequent must needs be constructed from phenomena accessible to practical observation. For instance, I find mysclf unable to account for certain phenomena in the dispersion of light. Then, on the basis of careful observation, I declare, 'If a molecule be a heary mass, connected by massless springs with a massless shell, then these observed phenomena come within the bounds of the explicable.' But the relative credibility of the antecedent hypothesis depends upon its relation to the consequent, and this, once more, is built from the facts encountered by me in the routine of observation. Evidently, then, the results of scientific method, whether laws or hypotheses, fall to be classed as interpretations of his experiences by a being for whom they occur thus and not otherwise. In short, they belong to the intellectual realm, liberated as completely as may be from every reference to desire (emotion) and will (wish).

${ }^{1}$ Cf. Modern Electrical Theory, Norman Robert Campbell, especially p. $23 \mathrm{I}$. 
Finally, what consequences emerge, as concerns the present subject? They present themselves in two guises - practical and theoretical. On the practical side, an impassable gulf separates the temper of science from the temperament of religion. By a steadfast instinct, the religious man refers invariably to a 'causc,' or causes, capable of explaining much more than stands in scicntific question as a usual rule. By acquired discipline the investigator of nature either rejoins, 'I cannot understand what you mean,' or answers, with decision, 'I find no trace of any such cause amid the phenomena I have observed.' In other words, for him the phenomena explain themselves from within, and, beyond this, no opinion can be passed upon them; he has been cured completely of -

"that insomnia which is God."

When Galileo's judges decided that -

"The doctrine that the earth is neither the centre of the universe nor immovable, but moves even with a daily rotation, is absurd, and both philosophically and theologically false, and at the least an error of faith," 1

their evidence consisted of preconceived dogmas (proven untrue since), and of an appeal to faith,

${ }^{1}$ Congregation of 22d June, 1633 . 
without pertinence in the ranges of physical research. Nothing could well seem further removed from their method than, for example, the astrophysical enquiries of the contemporary astronomer. And, if the practical test be applied, the result leaves no room for doubt. The propositions of the Prelates and Cardinals do not work; those, say, of the Director of Lick Observatory do. Nevertheless, religion and science remain integral to life equally; therefore a large discrepancy must lie secreted somewhere.

When we uncover the theoretical consequences, the precise nature of the situation begins to loom up. The conjunct enquiries of the sciences converge on the decision that the universe is a single, if extraordinarily ramified, system of energy. At all events, we gather this inference from observation and experiment, no matter in what field. Not only so, we can and do deduce it from the most stable and authentic principle yet compassed by the human mind, - the dynamical generalization, outlined by Newton, and clinched since, in numerous unanticipated ways, by many others. Moreover, energy provides an ultimate to which everything else may be reduced. Starting, then, from this base-line (the most carefully and accurately surveyed that we have, remem- 
ber), What follows? Adapting an ancient affirmation, the final juctgement formulates itself thus: the heavens declare the glory of Newton and Kirchhoff, the earth showeth the handiwork of Helmholtz and Darwin. One epitome of the cosmos goes glimmering, another illuminates the firmament, full-orbed.

At this late day it were superfluous to point out that these doctrines are not synonymous with materialism, for materialism has been relegated to the bottomless limbo of epistemological discards. Nevertheless, they intimate, with no uncertain sound, that nature presents itself as a self-explanatory totality. Even in the tenuous region of mind, natural causes are found to suffice for natural effects. As Huxley said, science means "the gradual banishment from all regions of human thought of what we call spirit and spontaneity." 1 When European culture had accustomed itself to the Copernican astronomy, no one objected to the substitution of mechanical law for supernatural design, so far as the stars in their courses were concerned. And the same story, substantially, can be related about the direful discoveries of geology and biology in the course of last century. The folk who assev-

${ }^{1}$ On the Physical Basis of Life, Collected Works, vol. i, p. 159 (London, 1893). 
erated that "the principle of natural selection contradicted the revealed relation of creation to its Creator," laid Darwin at Lyell's side in the hallowed fane twenty-two years later. And, in our own persons, a similar movement has operated to vaster issues after another lapse of a quarter century. Educated men, at least, agree to accept natural explanations, not only for foreign objects in the stellar offing, but, through the offices of chemistry, physiology, and biology, for the nearest intimacies of their own flesh. Nay, not content with these triumphs, science has essayed a bolder step. The evolution hypothesis has laid hold upon the distinctively spiritual organization. Psychology, for instance, and anthropology in its festooned ramifications, proceed upon a naturalistic basis no less confidently than the sciences of 'external' nature. Huxley's affirmation, if a statement of fact in his day, bears the semblance of a prophecy to us. For, materialism, thrust from the front door of the scientific edifice with mighty clangour, has been succeeded by a new tenant, smuggled in quietly at a side entrance - one like-minded, if less disagreeable. Naturalism is in occupancy.

Now Naturalism pivots fundamentally upon the doctrine of evolution, nay, upon the doctrine of 
evolution interpreted in one way, and therefore committed to the exclusion of certain competitive views. Drawn synoptically, the position may be outlined thus: the most complex phenomena of nature are reducible to simpler, these to still simpler, until, at length, one arrives at bed-rock in determinations of motion, capable of synthesis and retention in mathematical formulæ. For psychology, -

"The soul and its faculties, the great entity and the small entities, disappear, and we have to do only with internal events, which as sensations and mental images translate physical events, or which, as ideas, movements, volition and desire, are translated into the physical events. ... Psychology is connected again with the laws of life and with its mechanism." 1

For the sciences to which physiology is basal, the most careful investigators -

"see no grounds for accepting a vitalistic principle that is not a physico-causal one." 2

Thus, -

"when we attempt to think out what the organization is, we almost unavoidably think of it as a structure having the properties of a machine, and working

${ }^{1}$ German Psychology of To-Day, Th. Ribot, p. 8.

${ }^{2}$ Regeneration, Thomas Hunt Morgan, p. 287. 
in the way in which we are accustomed to think of machines as working." 1

Again, -

"During the last twenty years the relation between the transformation of matter and energy has played a prominent part in physiological research.... Robert Mayer and Helmholtz announced the principle of the conservation of energy and regarded its applicability to the human organism as an axiom. Recent investigation has done notable service in proving this axiom with certainty. It was demonstrated, in the case of animals at rest, that the heat given out was exactly equal to that of the combustion of the substances assimilated in the body (Rubner).... After having resolved the simpler problem of determining the transformation of energy in the resting body, the more difficult task of measuring this transformation during work was undertaken. By modification of the above-indicated methods one is now able to find out precisely how much nourishment the animal organism must use if it is to perform a definite amount of mechanical labour.

"American investigators, Atwater, Benedict, and their fellow-workers, have recently, in a very complete way, followed the transformation of matter and energy in man, under various conditions of nourishment, and occupation. The respiratory calorimeter

1 Regeneration, Thomas Hunt Morgan, p. 28I. 
which they constructed is the most perfect machine that has hitherto been devised for the study of the transformation of matter and energy in living animals. With these investigations concerning the amount of matter and force needed by man and beast in various work, together with the study of the most efficient foods, the physiology of nutrition enters into hygienic and sociological questions of the greatest significance." 1

Or, as our foremost American authority, Professor Jacques Loeb, holds, instincts have developed out of reflexes, thinking out of instincts; thus, as biochemical research seems to prophesy, the whole problem of human thought will be explained finally in terms of physical chemistry.

And so the incomplexity - by comparison - of chemistry and physics is reached, and we find ourselves dominated thoroughly by the mechanical theory, the most abstract, and therefore the most workable and accurate, of all human generalizations. Consequently, in the last analysis, every research yields to a resolution "als Mechanik der Atome." ${ }_{2}$ Throughout the entire welter of phenomena, this

${ }^{1}$ The International Quarterly, vol. xii, No. 2, pp. 327-328, Nathan Zunz (The Progress of Physiology).

${ }^{2}$ Cf. Die Willenshandlung, Hugo Münsterberg, p. 9, and passim. 
account suffices, whatever our religious views; and we abide by it implicitly in practical affairs, - in engineering, in dietetics, in the regulation of public health, in domestic plumbing, and so on. The mechanical theory is over all our works. The uniformity of nature, widening ever as research blazes its laborious trail, seizes fresh phenomena and affords such explanation as is attainable under the inexorable circumstances. For our present subject, the gravity of the conclusion can scarcely be exaggerated, because, if it hold, 'Christian truth,' in any conventional codification of it, has fallen upon irremediable bankruptcy.

Nakedly set forth, the theory comes to this. Observation and experiment, as conducted under rigid conditions in the natural sciences, combine to show that the universe is to be adjudged unalterably a mechanism. The human body, on the current reading of evolution, cannot be regarded as other than a bit of this mechanism, while consciousness sinks to the level of an 'epiphenomenon,' a side issue, of the nervous system. So all the activities, segregated from the purely physical world traditionally, under the term 'self-consciousness,' take their places among the other facts of nature. No break asserts its presence. This granted, every vestige of 'Christian 
truth' disappears, a more completely baseless fabric of a dream never sprang from fond, unchastened imagination. Even if aspiration be allowed some free play, as a kind of charity, the utmost comfort available to ease the sombre burden of life simmers down to that neo-Stoicism taught openly now in several quarters.

"Brief and powerless is man's life; on him and all his race the slow sure doom falls pitiless and dark. Blind to good and evil, reckless of destruction, omnipotent matter rolls on its relentless way; for Man, condemned to-day to lose his dearest, to-morrow himself to pass through the gate of darkness, it remains only to cherish, ere yet the blow falls, the lofty thoughts that ennoble his little day; disdaining the coward terrors of the slave of Fate, to worship at the shrine that his own hands have built; undismayed by the empire of chance, to preserve a mind free from the wanton tyranny that rules his outward life; proudly defiant of the irresistible forces that tolerate, for a moment, his knowledge and his condemnation, to sustain alone, a weary but unyielding Atlas, the world that his own ideals have fashioned despite the trampling march of unconscious power." 1

At the moment, it is none of my affair to attempt adjudication upon the adequacy, much less the truth,

${ }^{1}$ Ideals of Science and Faith, p. 169, Hon. Bertrand Russell (An Ethical Approach); edited by the Rev. J. E. Hand. 
78 MODERN THOUGHT AND THE CRISIS IN BELIET of these systematic inferences. Rather, my point is taken thus: they proclaim a crisis that admits of no half-measures, of no paltering in any shape. Confronted thus, as we are, it were worse than useless to rehearse hoary propositions formulated at a time when other possibilities engaged mankind; it were mere folly to fold one's hands, so to speak, and indulge a soporific hope that, somehow, all may end well. These things do not lie on the lap of the gods, they happen to be human issues, amenable to human influences, and to none other. As a matter of plain fact (forgive me for reminding you once more), western civilization accepts the concatenation of phenomena, whence such riews have precipitated, at every turn in practical life. Your railroads and trolley cars, your telegraphs and telephones, your hospitals and laboratories, in brief, the thousand things that constitute the very possibility of all that you term civilization, were created by the devotion of many who, in loyalty to their own insight, feel constrained to these positions. Moreover, as concerns knowledge itself, on the theoretical side, the average man agrees to-day that the astronomer and physicist, the chemist and physiologist, the biologist and physician, the psychologist and philologist, have earned the right to speak with authority. The old-time 
scribes have met their Waterloo, as many recognize, if in dazed fashion. Or, to put the case otherwise, science has become such an enormous power in the most ordinary affairs of existence, and no less in the circumambient perspective wherein we set the import of our lives, that it were fatuity to suppose ourselves able to disregard even its extremest pronouncements. To adopt its advice when useful or pleasant, to pass it by on the other side when it constrains or seems distasteful, is a course closed to the reflective mind. That numbers have availed themselves of this subterfuge during the past generation throws no lustre on human perspicacity. That an evasion so obvious can continue, the trend of the intellectual events from day to day shows, decisively, to be out of the reckoning. To use a homely phrase, 'you can't eat your cake and have it.' Either you must capitulate at discretion eventually, or you must be prepared to reconsider, de novo, the place of religion in experience. The naïve simplicity of orthodox belief, so called, has gone beyond recovery. Disaster or not, mental innocence has eaten of the tree of the knowledge of good and evil at the hands of science. This, at a minimum, stands beyond question. Whether, on the other side, naïve heterodoxy has proven itself a defensible consummation is an entirely 

different affair. In any event, it serves itself now as a philosophy of the universe; despite its multiplied placards, erected in warning against 'metaphysical quagmires,' it parades, not merely as a metaphysic, but as a metaphysic of a highly dogmatic type. We may say, therefore, "Thou hast appealed unto Cæsar; unto Cæsar shalt thou go." 1 But, meantime, this appeal releases nobody from the obligation to recognize the immense change frankly, to become familiar with its basis, factors, and logic.

${ }^{1}$ Acts xxv. I 2. 


\section{LECTURE III}

\section{BREACHES OF THE HOUSE}

Even if he admit the validity of scientific method, and appreciate the sweep of the scientific view of the universe, the dogmatic Christian may yet exclaim, "Our withers are unwrung!" Undoubtedly, he may allege that the natural sciences, while paramount in affairs pertaining to the physical world in its widest scope, cannot deal with spiritual life. He may remind himself that affection, and devotion, and worship elude mathematical formulæ, are intractable to causal relationship, and, more than likely, evade the grasp of mechanical, chemical, or physiological characterizations. Nay, as matter of record, religion has continued to maintain itself inviolable against the assaults, say, of materialism in the mid-nineteenth century, by a more or less conscious affirmation of this very argument. The average man cannot be expected to realize that the weapon cuts both ways, that it is as dangerous to the user, religion, as to the intellectual constructions attacked. Therefore we may admit tha plea for the 
moment. But, when one comes to historico-critical research and its conclusions, no such extenuations avail. History and criticism stand on the same plane with religion. They deal with self-consciousness, proceed from it. In short, the breaches they effect are "breaches of the house," not merely devastations, perilous, maybe, but perilous afar. Here, then, we must anticipate an internal assault, one from which no easy way of escape offers. If science threaten, history and criticism seem in a position to command.

\section{The Historico-Critical Movement}

As its title implies, the historico-critical movement belongs to that most modern group of investigations known generally by the name 'human' sciences. From the earliest times till within recent years, the activities typical of mankind were sequestered from exact enquiry. " Order, Heaven's first law," appeared to be set at defiance by the multifarious chances of society, morals, art, and religion. Myth, legend, and marvel found congenial environment here, because they alone sufficed to bridge yawning gaps; while supposition, no matter how far-fetched, did duty for objective fact as concerned phenomena so rooted in the recesses of psychological peculiarity 
that the resources of intelligence were foiled. Thus mystery cloaked human doings on all sides, and eren the most penetrating scientific minds were nowise loath to admit that the universe was dual - a natural order expressing itself without variableness or shadow of turning, and an inward spirit, flashing forth with caprices so strange that suprahuman intervention became a regnant postulate.' But, in the wane of the eighteenth century, several thinkers, especially in Germany, began to suspect that diligent study of the past might "lead into the council chamber of fate," to use the words of Herder, in whose seminal works, "Folk Songs," "Ideas on the Philosophy of History of Mankind," and "God, Friendly Conversations," this suspicion crystallized into something like system. Hegel, the only philosopher whom modern Europe can place beside the masters of those who know, - Plato, Aristotle, and Spinoza, articulated Herder's suggestions, and, since his death, in I831, thanks mainly to his epoch-making fermentum cognitionis, supplemented by that of Comte in France, an extensire group of expert investigations has concentrated upon the elusive theme. Anthropology, archæology, philology, in their numerous ramifications, the historical disciplines, and allied

${ }^{1}$ One of my own teachers, the late Lord Kelvin, countenanced this position. 
studies have torn the veil of mythology from man's past, and taught us to regard his present as part of a vast self-developing order. We have learned that all articulated knowledge is science, that operative principles can be discovered, not merely in the physical universe, but even in the most unlikely corners of the psychological realm. In a word, the transformation of possible views concerning humanity is almost more profound than the parallel reversal in the natural sciences.

The barest description of a field so immense is quite beyond my competence. It may help, however, if I attempt to illustrate the general process by reference to a single case with which, in all likelihood, you possess some acquaintance - I mean the civilization of ancient Greece.

When the foremost classical scholars of the day were schoolboys, Greece enjoyed a comparatively brief history, as history counts now. Moreover, she seemed isolated in exceptional fashion, and her sudden cultural efflorescence was a perennial wonder. The Homeric poems were conceived, and rightly, as legends in romantic form, dating back probably between the eleventh and eighth centuries B.c. Full of picturesque traditions and enthralling story, even their most vivid descriptions could not be verified 
historically. As products of poetic imagination they were magnificent, unparalleled; as reminiscences of an actual civilization they implied little, and served only to engender speculations impossible to check. Indeed these speculations flourished luxuriantly. But, after 1870 , Greece gained even more reality than she had possessed hitherto. The discoreries of the temple and halls of Olympia, by Curtius and his colleagues, injected fresh life into the glorious fifth century. At Pergamon Conze uncovered the colossal work, such as the wonderful altar, characteristic of Hellenic genius after Alexander the Great. Meanwhile, almost in the twinkling of an eye, the mythical Greece of Homeric legend was set before an astonished world. From I 870 to 1885 the remarkable and manifold discoveries of Schliemann, at Hissarlik, Mycenæ, Orchomenos, and Tiryns successively, revealed the existence of a complex prehistoric culture, antedating the Homeric poems by four centuries or more. While it may be doubted whether Schliemann recovered the grave of Agamemnon and the treasure of Priam, or explored the house of Atreus, it is true that he barcd the palaces of Homeric rulers, and that he compelled the reconsideration of the course of civilization in what was to become 'Greece.' In any event, the end was not yet. The French ex- 
cavations at Delphi, the Jerusalem of Greece, those of the Americans at the Argive Heræum, the metropolitan shrine of pre-Homeric times, served to whet expectation, to dissipate some difficulties, and to create others. Nor is this all.

Writing about twenty-five years ago, in full acquaintance with Schliemann's larger results, one of the most judicious historians of Greece said:-

"Another example of the infiuence of imagination on the form assumed by early history is furnished by the personality of Minos. In Homer he is a son of Zeus. . . . Hesiod makes him rule with the sceptre of Zeus over many men dwelling around him. . . . Herodotus makes Minos rule over the islanders. . . . According to Thucydides, Minos was the first king who possessed a fleet of war. . . We hold, on the contrary, that Minos is a mythical personage, like Perseus and Heracles, and that the actions which are ascribed to him as history are nothing but a gradual accretion of legendary embellishments. We might just as well look upon his colleague Æacus as a historical personage, and commend his mild rule over his people." 1

Yet, as the first months of the twentieth century dawned, an English investigator ${ }^{2}$ found,

${ }^{1}$ History of Greece, Adolph Holm, vol. i, pp. 49-50 (Eng. trans.).

${ }^{2}$ Dr. Arthur J. Evans, Keeper of the Ashmolean Museum, Oxford. 
in Crete, marrellous evidences of a great cmpire, based on sea power, over which this same Minos ruled. ${ }^{1}$ The Homeric tradition, that Minos lived before Agamemnon, like some of the other traditions mentioned by Holm, received unforeseen confirmation. The palace at Knossos, let alone numerous other discoreries, at Zakro, Palaikastos, Præses, Mount Ida, Mount Dicta, and Vapheio near Sparta, raise problems of the most acute interest, bring much prehistoric mystery to the light of open day, and make it possible to initiate enquiry into what may come to be termed 'Agean' civilization. As with Schliemann, so here, it may not be true that Dr. Evans has found the storied Labyrinth and tracked the awful Minotaur to his familiar haunts, or wandered in the palace of Alcinous. But he may have set back a civilization to which "we are justified in applying the name Greek" 2 to a period $3 \mathrm{SOO}$ B.C., that is, relatively as early as our knowledge of Egypt; nay, he may have furnished warrant for the inference that primitive man made his home here at a time when the Sumerians were

${ }^{1}$ I do not imply that $a$ Minos was historical, of course; the name is possibly a title, like Cæsar, or, like Creon, may mean simply a ruler. On Crete as a 'world-power,' see Les Phéniciens et l'Odyssée, Victor Bérard, vol. i, pp. $225 \mathrm{f}$.

${ }^{2}$ A. Furtwängler in the International Quarterly, vol. xii, p. Iog. 
founding their city on the Persian Gulf. However this may turn out ultimately, the ascertained facts afford plenteous surprises. A modern lavatory and drainage system, examples of the goldsmith's art unrivalled except by the Italian craftsmen of the Renascence, plaster work fit to stand comparison with the sculpture of the classical age, achievements in porcelain so excellent as to suggest connexion with the idealized plaques of the shield of Achilles, ${ }^{1}$ numerous intaglios graven finely with various monsters, a system of weights and money, clever miniatures on crystal, mural paintings of tribute bearers, - all point to a forceful empire, pulsating with intense life, far away in the mists of a dim antiquity. The palace of its monarchs, as now excavated, taken with the accessories found there, may well render the famous passage in the "Odyssey" 2 no romantic legend, but rather a memory of an impressive fact; while the paved Theatral Area cannot but recall the dancing ground "such as once in spacious Knossos Dædalus fashioned for Ariadne of the braided hair." 3

${ }^{1}$ Iliad, xviii, $478 \mathrm{f}$.

2 viii, $83 \mathrm{f}$.

3 Iliad, xviii, $590 \mathrm{f}$. The first building at Knossos is striking in its non-Hellenic character; the Cretan palace is a labyrinth of rooms, the Northern (or Hellenic) Megaron is one-roomed; at Mycenæ and Tiryns, for example, the two styles are found in combination. 
Who these Minoans, master-builders and rare artists, may have been, scholars are not yet clear. Their work intimates at least that Periclean art was no fatherless sport in the Egean environment. Moreover, their religion offers pregnant hints, full of intricate problems. It centred round the cult of a female divinity, evidently a nature-goddess, and therefore associated with fertility. ${ }^{1}$ With her an obscurer being, a god, was worshipped, and held in regard sometimes as her son, sometimes as her husband. This collocation, so strange to us, at once suggests the parallel of Ishtar and Tammuz, with its very remote goddess-mother and long retinue of persistent myths. Traces of fetich worship, kindred with the Semitic, exist also. The trilith, or sacred portal, at Goulas, the asherahs and massebas, the sacred doves and dovecote, the tree cult, must compel further enquiry and, at length, serve to extricate some questions intractable now. And so the problem of the relation between Minoan and Semitic culture becomes urgent, especially if, as some were formerly wont to think, Sargon of Agadè never saw the "Upper Sea." Can the one enable us to understand the other better? Did they come into contact? if so, how and when, and how intimately? If not,

${ }^{1}$ She was also the queen of wild beasts. 
what comparative results can we extract from analysis of the respective cults? Again, can it be maintained that Phœnician art was no more than Minoan in a decadent stage? In view of Dr. Evans's 'library' from the palace, containing about one thousand tablets, written in a clear script, which antedates Phœnician writing by five centuries, what are we to say next of the settled opinion that assigns the Greek alphabet to Phonician sources? Was an IndoEuropean language the medium of communication in the Egean basin during the Minoan supremacy ? ${ }^{1}$ When scholars acquire the key to the Knossos tablets, shall we be able to close the gap between Eastern and Western civilization so called? What is the relation of the Minotaur to the Hittite god (Sutekh ?) standing on a bull? What about the double-headed axe of the Cretan Zeus and the same weapon of the Hittite Amazon priestesses, the traditional founders of Ephesus? Did Crete give Zeus to Greece, or do we only find very primitive elements in the worship of the god, throwing light, possibly, on his origin ? ${ }^{2}$ How did Zeus-worship evolve from that of the

${ }^{1}$ It is well to recall that the names Larisa, Zakynthos, Arisbe, Narkissos, and the like are not Greek.

2 'Zeus' may be merely a late conventional way of naming the Cretan bull god. 
Nature-Mother? Can we trace a parallel evolution of Yahwéh?

In like manner, the brute-headed men on the Minoan seals, although they present affinitics with Babylonia, refer one immediately to Egypt. And the same problems arise. Whatever may be the final consensus of scholarship as to details, it is probable that the Cretan excavations have disclosed a civilization of Oriental, rather than Occidental, temper. Minoan culture belongs with the Near East, not with western Europe, even if its cursive script may yet conceal much. It may be, for example, that the Cretan empire builders and the ancient Libyan race of Egypt are of common stock. If so, then we must look for the roots of Greek civilization in Africa! Now for our present point. 'Egean' culture as Asian (or African) is a startling idea to those of us who have been taught time out of mind to consider Greece the bulwark of European salvation from 'barbaric' eastern conquest. Nay, our boyhood tradition hails from Plato: "We are pure Hellenes," he says," "having no admixture of foreigners, and therefore the hatred of the barbarian has passed unadulterated into the life-blood of the city." These, and similar discoreries, serve to show how a priori

1 Menexenus, 245. 
theories and speculative possibilities must yield to transformation in face of new knowledge, and give way before transitive rearrangement of familiar, but misunderstood or obscure facts.

This resurrection of the past forms but one of many triumphs wrought by the 'human' sciences these last three generations. Sumerian, Babylonian, Elamite, Hittite, Assyrian, Egyptian, Chaldxan, and Persian overlordships, to say nothing of the civilizations peculiar to the Far East, have paraded before our rapt gaze. And we realize, for the first time, that the history of human culture presents itself as a long, slow process amenable to explanation from within. We elicit the meaning from the facts, not by reference to a presumed supranatural interference from without. The respective attitudes of research and ignorance are nowhere better illustrated than by Dr. Evans's own account of his discovery of the splendid fresco, the "Cupbearer," at Knossos.

"In carefully uncovering the earth and débris in a passage at the back of the southern Propylæum there came to light two large fragments of what proved to be the upper part of a youth bearing a goldmounted silver cup. The robe is decorated with a beautiful quatre-foil pattern; a silver ornament appears in front of the ear, and silver rings on the arms and neck. What is specially interesting among 
the ornaments is an agate gem on the left wrist, thus illustrating the manner of wearing the beautifully engraved signets of which many clay impressions were found in the palace.

"The colours were almost as brilliant as when laid down over three thousand years before. For the first time the true portraiture of a man of this mysterious Mycenæan race rises before us. The flesh tint, following perhaps an Egyptian precedent, is of a deep reddish brown. The limbs are finely moulded, though the waist, as usual in Mycenzan fashions, is tightly drawn in by a silver-mounted girdle, giving great relief to the hips. The profile of the face is pure and almost classically Greek. This, with the dark curly hair and high brachycephalic head, recalls an indigenous type well represented still in the glens of Ida and the White Mountains - a type which brings with it many reminiscences from the Albanian highlands and the neighbouring regions of Montenegro and Herzegovina. The lips are somewhat full, but the physiognomy has certainly no Semitic cast. ${ }^{1}$ The profile rendering of the eye shows an advance in human portraiture foreign to Egyptian art, and only achieved by the artists of classical Greece in the early fine-art period of the fifth century B.c. - after some eight centuries, that is, of barbaric decadence and slow revival.

${ }^{1}$ It may be noted that the purest type of the Semite is the Arabian, and that type does not correspond to the one generally suggested by the word 'Semite,' viz. the Jew and Assyrian. 
"There was something very impressive in this vision of brilliant youth and of male beauty, recalled after so long an interval to our upper air from what had been till yesterday a forgotten world. Even our untutored Cretan workmen felt the spell and fascination. They, indeed, regarded the discovery of such a painting in the bosom of the earth as nothing less than miraculous, and saw in it the 'icon' of a Saint! The removal of the fresco required a delicate and laborious process of underplastering, which necessitated its being watched at night, and old Manolis, one of the most trustworthy of our gang, was told off for the purpose. Somehow or other he fell asleep, but the wrathful Saint appeared to him in a dream. Waking with a start, he was conscious of a mysterious presence; the animals round began to low and neigh,

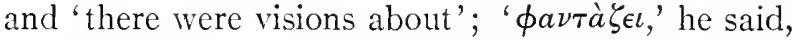
in summing up his experiences next morning, 'the whole place spooks.'" 1

${ }^{1}$ The Monthly Review, March, I90I, pp. I24-125. In the number for January, I9or, of the same magazine, see Mr. D. G. Hogarth's article on The Birth Cave of Zeus (pp. 49 ff.). Further details, in articles by these authors, and by Messrs. F. B. Welch and Duncan Mackenzie, are to be found in the Journal of Hellenic Studies (London), especially vols. xxi and xxii; also in the Annual of the British School at Athens. The most convenient synopsis of the whole subject, with the literature complete to date, is offered in The Discoveries in Crete and their bearing on the History of Ancient Civilization, Professor Ronald M. Burrows (London, 1907). 
Dr. Evans emborlies constructive criticism, Manolis naïve presupposition.

Accordingly, we may now ask, What is the historico-critical attitude? On the historical side, this point of view teaches that man's spiritual life presents an organic whole, governed by immanent principles peculiar to itself. Culture-history thus discloses its secret in an unbroken series of manifestations and, wherever the import of the process has been penetrated, a self-controlled unity has afforded satisfactory clews. No doubt, the differentiating principle that interpenetrates all continues to defy deepest plummet. To assert that its "stream of tendency" is 'necessary,' reduces the mystery not a whit. Nevertheless, we seem to see at least that the sole medium of the revelation is man himself. To adopt Tieck's phrase, civilization (in the sense of culture) possesses "its own centre, its own soul, as it were, from which the controlling spirit penetrates all parts, even the most remote." To reconstruct this synthetic activity is the aim of historical method. And, so far as the perplexing task has attained success, history has reconstituted itself, because it has proved to be a self-propelled growth. Thus, on the side of its larger setting, the historico-critical method turns out to be philosophical, and "is an endearour 
to import unity and connexion into the scattered directions of cultural thought, to follow each of these directions into its assumptions and into its consequences." 1

The critical factor of the process differs little in temper and procedure from any other kind of science. In a word, it must be classed with ordinary inductive knowledge. By application of the inductive method to languages, literary documents, monuments, objects of art, pottery, traditions, and the like, controlled effort is put forth to elicit what they have to tell about themselves. The Egyptian monuments, the cuneiform inscriptions, the Vedas, palimpsest Mss., Thucydides's "History of the Peloponnesian War," Xenophon's "Memorabilia," the contents of the New Testament, and so on, yield information about themselves whereby we arrive at a definite grasp upon what they were and imply. In all cases alike the same standards and processes apply. Thus scholars essay to set the materials in their real relations and, by a consecutive system of checks and balances, to reduce them to consistency with themselves and one another. In this manner they place men in a position to guard themselves against misconception, or naïve inference, and deliver them

${ }^{1}$ Grundzüge der Logik, H. Lotze, sec. 88 (Ist ed.). 
from the substitution of preconceived belief or opinion for objective fact. As a result, explanation precipitates itself from within the circle of the evidence, and extraneous interference becomes a superfluous hypothesis. The analytic exhibition of origins and concomitant conditions enables the expert to pass from individual cases to a synthesis of principles that holds valid universally for similar phenomena. The corrupt Hebrew, the imaginary history, and the apocalyptic fiction of Daniel, for example, prove the book a product of the Maccabrean epoch, just in the same way as Plato's language, and the development of his technical doctrine, throw light upon the order of the Dialogues. The exhibition of sources, that is, leads to an elucidation of credibility, scope, and significance. Pelops and Cadmus were the ancestors of the Greeks precisely as Abraham and Jacob of the Israelites. We have no more reason to believe that Plato took down the sayings of Socrates on the spot, and transcribed them in the 'Socratic' Dialogues, than that the Synoptists performed a like office for Jesus. Above all, both problems are to be settled by the exercise of identical discrimination, by the use of the same standards - there happens to be no other way. Results may diverge widely in detail, exactly as they do in the natural sciences, but the method of 
approach and the attitude before the evidence must remain unchanged for all cases equally.

"No Tyrian trader from the world shall hoard

His splendour for salvation, no dismay

Shall rant on flame-bursts, nor to element

Resign the soul! But something of a faith

In understanding of a modern mood

Shall mean God most in complications sprung

Of fluxion, spring-life and the lift of earth

Inevitable. And my theme shall be . . .

Let the new creed afford right meaning for

The creed rejected, let the new art show

Old myth subordinant, old metaphor

But outworn fact: thus, the new fact full truth.

* * * * * * * *

No sceptical dismay

More, nor withdrawal from the market-place

And sphere of high contention faith with faith!

Here is earth's wonderful sweet market-place

Of blossoming contention - 'would my soul

Had learn'd herself so as a world of men!'"

We see, then, that the historico-critical movement is not encompassed with any sort of mystery. It amounts to an attempt on man's part to master the meaning of his own past by reference to principles that reach formulation only on the basis of exact inquiry, and complete loyalty to the canons of ordinary experience. Trace the phenomena to their 
historical origins, follow out their life career, and it will be found invariably that they suffice to systematize themselves; the rest is conjecture. The identity, mutatis mutandis, between the relations of the 'Powers' of the Near East in the time of the Tel-el-Amarna "Letters," and those of the European 'Powers' in our own day, is almost laughable. But, till criticism exploited the "Letters," and history drew the unaroidable inferences, this knowledge failed us. ${ }^{1}$

The materials, then, are, on the one hand, problems to be solved; on the other, ideas to be appreciated. The results garnered wield moral influence chiefly; they are calculated to impress the will by altering one's attitude towards the enthralling drama of history. Nevertheless, as contrasted with the scientific consciousness, the historico-critical movement has remained more or less "cairiare to the general," and for evident reasons. It depends upon evidence difficult to glean, and still more difficult to master, so as to be able to interpret it. It appeals to fluid qualitative judgements rather than to practical (and therefore simple) quantitative standards. Most of

${ }^{1}$ An excellent description of the historico-critical method is to be found in vol. $\mathrm{i}$ of The Hexateuch, by J. Estlin Carpenter and G. Harford-Battersby (London, r900). 
all, the social mind has never associated it with a rough-and-ready theory of the universe which, on account of its evident, if profound, implications for life, obtains widespread attention in print designed specially for the popular eye. And yet, as I have said, its thrust into the traditional views of religion is more radical by far. Let us look at this for a little, concentrating attention upon the biblical narratives and documents.

\section{Ancicnt History}

At the outset it is imperative to realize that we must slough all ideas of chronology, and of the pivotal importance of the "seed of Abraham," traceable to dogmatic opinions about the 'books of Moses.' According to these delusions, a period of ${ }_{1} 65^{6}$ years intervened between the Creation and the Flood, of 290 years between the Flood and the birth of Abraham, of 720 years between the birth of Abraham and the Exodus - 2666 years altogether. Adam, and the other worthies who peopled these two and a half millennia, were conceived to be historical personages as a matter of course; nay, more, their careers were moulded by a tendency that proceeded from Yahwéh in a series of special revelations. The Deity interposed directly, from time to time, to promote 
the welfare of Israel; in short, the universe was created with particular regard to Israel's mission ; universal history circled round this vocation; all else was subordinate. We are aware now that, while these pious recitals may serve to edification, their historical conspectus is totally untenable. The Creation, a sinless Adam in Paradise, the Fall, the confusion of tongues, and the rest, may remain passing good folklore; they never happened in the course of culturehistory. The chronology, that is, has no basis in fact, while the glamour that surrounds Israel amounts to a freak of late fancy playing upon legends relative to a mythical past. The truth, so far as ascertainable, tells a very different story.

Take a map of western Asia and northeastern Africa, place a pair of nut-crackers upon it so that the hinge lies on the Gulf of Issus; now move the right-hand leg till it passes beyond the eastern shore of the Persian Gulf, covering Susa; move the lefthand leg till it coincides with the Nile valley and covers Thebes. The territory enclosed by this baseless triangle includes the biblical lands. Next, keeping the hinge steady, bring the right-hand leg down sharply, move the left-hand leg slowly about an inch - the line of pressure and contact will coincide with Palestine. The one movement indicates the fre- 
quent and rapid incursions into Palestine from the Euphrates-Tigris valley, the other the more leisurely and less frequent invasions from Egypt. Further, as compared with the sweep of the extended legs, the narrow line of junction denotes the relatively small geographical extent and importance of the Promised Land. It is a tiny thing, squeezed continually between world-empires. Even for the brief period under David and Solomon, when the consolidated Israelitish territory became rather larger than Massachusetts, and when its 'world-power' ran from Kaciesh and Damascus in the north to Beersheba and, possibly, Elath, on the Gulf of Akabah, in the south, it was never equipped to compete on equal terms with its mighty neighbours. Moreover, an Israel bounded on the north by Kadesh and Laish, on the south by Gaza and Rabbath Moab, was an ideal rather than a reality, the short time of Davidic prosperity aside. Indeed, so rapid was the decline after the blaze of glory that attracted the Sabran queen, and enabled Solomon (as opinion still runs) to marry a Pharaoh's daughter, that, in 750 B.C., Israel's territory measured but one hundred miles from north to south, seventy-five from east to west; while little Judah, the eventual heir of the apocalyptic tradition, included just fifty square miles. What 
could they do against Assyria, or Babylon, or Egypt, against empires ruling, sometimes, 230,000 square miles of the richest country in that world? Little, except as their powerful enemies fell upon weakness, as in the days of Jeroboam H, or of the Hasmonxans, when "the yoke of the heathen was taken away from Israel."

This reversal of perspective regarding temporal importance finds parallel at least as transforming when we come to questions of chronology and the history of culture. It seems a far cry to the dawn of the Christian era. The obscure migration - one of several like it - whence the legendary personality of Abraham was precipitated, runs back from the first Christian century just about the same period as we date forward from it. And yet the exquisite silver vase of Entemena, the priest-king of Lagash, in southern Babylonia, transports us to a time nineteen hundred years before the Abrahamitic migration. ${ }^{\text {t }}$ Nevertheless, even Entemena was a modern man, if we grope to the first settlement of Eridu, the city of the god Ea, by the Sumerians, some $6_{500}$ B.c. ${ }^{2}$

${ }^{1}$ Cf. Explorations in Bible Lands, H. V. Hilprecht, p. $24 \mathrm{I}$.

${ }^{2} \mathrm{Cf}$. Babylonians and Assyrians; Life and Customs, A. H. Sayce, p. 2. Professor Sayce's date is based upon the rate of alluvial deposit in the Persian Gulf from the time of Alexander. It should, 
Nay, when we quit history for myth, the Babylonian calculations put the biblical to utter shame. From the Creation to the Deluge ten kings reigned for 432,000 years; from the Deluge to the Persian conquest was an astronomical period of 36,000 years. But, without trenching upon myth, or calling attention to the remarkable correspondence of the Babylonian figures with the conclusions of modern science as to the age of man upon earth, the bare facts furnish food enough for reflexion.

The people known to us as the Hebrews belonged to the Semitic stock which, as recent investigation has proved, played a foremost rôle in the development of human culture. While it is difficult to formulate the divisions of the race in a manner entirely satisfactory, any one of the several arrangements adopted by scholars serves to show wide extension, exceptional vitality, and primary importance. Thus, for example, the North Semites fall into four divisions, viz.: (I) Babylonian (Old Babylonian, Assyrian, Chaldæan); (2) Aramæan (Mesopotamian, Syrian); (3) Canaanitic (Canaanites, Phœnicians); (4) Hebraic (Hebrews, Moabites, Ammonites, Edomites).

perhaps, be stated that Eridu is said to have been on "the shore of the sea" in the reign of Dungi, son of Ur-en-Gur, cir. 3000. Cf. Orient. Lit. Zeitung, 1907, S. $5^{8} 3$. 
There were three groups of South Semites, viz., (I) Sabrans, (2) Ethiopians, (3) Arabs. ${ }^{1}$ The fortunes of the Hebrews form part and parcel of Semitic civilization as a whole, and at a late period, comparatively, in its development. So much so that, if we recall the picturesque story of Joseph, we must recognize many waves of migration from Arabia, not merely in subhistorical, but also in prehistoric, times. With these the "chosen people" were intertwined inextricably, and they formed no exception to a very general rule. Causes operative elsewhere, and on a much larger scale, suffice to explain the recorded phenomena, when they have any historical basis.

The course of events prior to the Exodus of Hebrew tradition may be outlined as briefly as possible. Apart from a general view of it, one cannot realize the import of later history and, very specially, adjust the focus.

Old Babylonia was settled in remote days by a non-Semitic people, the Sumerians. They were city folk, and the city appears to have been the unit of government. The principal settlements of this prehistoric age were Eridu, on the Persian Gulf, Ur, some forty miles west on the Euphrates, and Nippur,

${ }^{1}$ Cf. History, Prophecy, and the Monuments, James Frederick McCurdy, vol. i, p. I9. 
about eighty miles northwest, near the centre of the plain between the Euphrates and Tigris. When the first Semitic hordes migrated to this region is not known. At all events, in farthest historical times, and earlier, a Semitic culture had blossomed here already, and the Sumerians had become incorporated in a civilization which, though influenced profoundly by the older race, was Semitic in general character. From this cosmopolitan culture the first great empire of western Asia came forth. So early as Sargon of Agadè, Palestine ranked with other Babylonian provinces. His son, Naram-Sin, obtained, amongst other spoil, a vase of Egyptian alabaster, itself indicative of the extent of his conquests. Nor was it a crude civilization that penetrated to Palestine thus early. Sargon's gem-cutters produced specimens of their art equal to the best work of later periods, and the bas-relief portrait of Naram-Sin rivals, if it does not surpass, the familiar masterpieces of Assyria two millennia after. Religion and law, government and commerce, had made distinct advances. Art had reached high development. The arch, so indispensable to large archievement in architecture, and supposed usually, until a recent date, to have been invented by the Romans about Ioo० B.C., was used in Babylonia nearly 3000 years before this time. About 
2700 B.C., when Gurlea was priest-king of Lagash, with Ur-Nina of Ur as suzerain, we find Palestine still under Babylonian domination, and this relation seems to have existed for at least two hundred years more. Then followed a second Arab migration, known as the Amoritic, which overflowed Hither Asia (including Palestine), South Arabia, and, possibly, Egypt. In 2225 B.C., we find a Semitic Pharaoh (Khyan) - a "lord of the desert," or chief of Beduin. These Amorites appear to have been absorbed by the populous Babylonia and Egypt, but in Palestine they maintained themselves as a separate people. After the disintegration of the Babylonian government resultant upon this incursion, the mountaineers of Elam, to the northwest of the EuphratesTigris plain, who had doubtless suffered chastisement at the hands of their more progressive neighbours, saw their opportunity, and attacked the wealthy lowlanders, sacking Nippur, and scattering destruction among the monuments of a civilization that had - already wielded overlordship for the same period as Christianity has now ruled the Western world. The much disputed fourteenth chapter of Genesis may be a Palestinian reminiscence of this raid; if so, the emigration of Abraham was an incidental phenomenon in a widespread movement. But the Elamites 
had to reckon with the Canaanite or Amorite invaders who thus preceded them. For from them sprang a dynasty whose main ornament was the famous juridical monarch, Hammurabi. According to the latest calculation, he reigned about I900 B.C., that is, seven centuries before the Exodus. Under him Babylon became the metropolis of western Asia, and entered upon her wonderful career as the holy city of this vast region. As some think now, not Jerusalem, or Rome, but Babylon, was "the mother of us all." Hammurabi not only redeemed the old empire from the Elamite yoke, but restored its supremacy to the shores of the Mediterranean. It can hardly be doubted that some of the legislation to be found in the "Book of the Covenant" (Ex. xx. 22-xxiii. 33; xxxiv. I I-26) was related closely to his great code, graven upon the black diorite pillar now in the Louvre. The dominion of Babylonia, thus reinaugurated by Hammurabi, was destined to last for four centuries. That Palestine prospered during this period, became, in fact, the "land flowing with milk and honey," we know from the Egyptian "Romance of Sinhuit." Agriculture and commerce flourished, civilization was accordant.

Yet a third migration brought this period to an end, when the Kassites, a Tartar-like people from 
central Asia, broke through Elam, and founded a dynasty in Babylon. In the same epoch a non-Semitic race, the Mitanni, carved out a kingdom on the headwaters of the Euphrates, and thus cut off Babylonia from her trade routes with western Asia. Synchronous with these movements was the successful invasion of Egypt by the Shepherd or Hyksos kings, who were Asiatics - possibly Semites, and who held rule in Palestine, after some sort, ere they overwhelmed Egypt, if Numbers xiii. 22 is to be credited. It is within the bounds of possibility that the eponyms of the Exodus set out upon their wanderings in this era, as a wavelet in the general unrest. The net result, as concerns the present theme, was the decline of Babylonia, whose commerce waned, and the rise of Egypt, to freedom first, then to worldempire, after she had expelled the hateful foreigners. With Thebes as base, the seventeenth dynasty began the Hundred Years' War which, under Aahmes, the founder of the eighteenth dynasty, resulted in the final rout of the Hyksos. If contemporary records run true, the defeated Shepherds retired into Palestine. The Egyptian monarch was compelled to pursue as a matter of mere prudence, and, eventually, his countrymen gained an Asiatic empire to the Euphrates plain. This was achieved by Thothmes 
III (I 493 B.c.), the mightiest of the Pharaohs, whose rule, assured at the battle of Megiddo in northwestern Palestine, extended over Upper and Lower Egypt, through the Sinaitic Peninsula and Palestine as far as Cœle-Syria, thence south and east, including the old kingdom of Agadè and Hammurabi, to the borders of Elam. Egyptian governors were placed in the conquered provinces, to render administration permanent. Thothmes died two hundred years before the Exodus, and his rearrangement of the civilized world maintained itself for a century. Later antagonists of Egypt, like the Hittites and Assyrians, are on friendly terms with Amenhotep III, as the Tel-el-Amarna "Letters" show. These letters, moreover, reveal the amazing fact that Babylonian civilization had become so engrained in Hither Asia that its language and script were the media of communication between educated people, and the sole proper form for diplomatic correspondence between rulers. Not only the dwellers in the Euphrates-Tigris district, but the Hittites, Canaanites, and even the imperial Egyptians themselves, employ it. It stood to this period and provenance as French did to eighteenth-century Europe, and communication in the ancient epoch appears to have been as frequent, regular, and easy as in the modern. An excellent postal ser- 
vice, conducted probably by Beduin, was in existence.

Religious dissension orertook Egypt in the next reign, and thereupon her power suffered decline. The Hittites descended upon Syria from the Taurus, and the Khabiri (probably another migration from Arabia) threatened Abd-khiba, the official who governed Jerusalem for the Pharaoh. The Hittite king, Sapalulu, made himself supreme to the north of Palestine, while Moab and Ammon, the "children of Lot," came to bear rule in the southeast. Notwithstanding this pressure from two sides, the Canaanite strongholds in central Palestine seem to have maintained themselves intact - a fact full of meaning. The fourth migration, the Aramæic, must be connected closely with the biblical legends of the patriarchs and their involuted domestic relations. This state of disorder in Palestine was ended by Sety $\mathrm{I}$ (I345 B.C.), who reduced the country to vassalage once more, carrying his conquest as far as Lebanon. His son, Rameses II, the most famous of Pharaohs, continued this policy, and came into conflict with the Hittites. After twenty years of indecisive fighting, both powers negotiated a solemn treaty of alliance whereby Palestine remained to Egypt, Syria to the Hittites. Having married the daughter of Khate- 
sera, the Hittite monarch, Rameses spent the remainder of his long reign in cultivation of the arts of peace. He blossomed into a great builder, using forced labour, like all Oriental potentates, and, in this connexion, took his place in biblical quasi-history as the "Pharaoh of the Oppression." When the "mixed multitude" of slaves - barbarians, as the Egyptians deemed them - fled into the desert, we do not know; no details survive that suffice to throw any light upon the subject. But over and over again we must emphasize the fact that it is only at this point in the tremendous panorama that Israel makes its first appearance on the stage, not of history, indeed, but of direct tradition. Whatever the Exodus may have been historically, the conditions for its occurrence erentuated between $125^{\circ}$ and I 190 B.C., when Egypt lay in a condition of civil anarchy. The shepherds of Goshen, if they mored, left during this period, and their descendants, several generations later, arrived eventually in a land which had been highly civilized for two thousand years, and had undergone already a series of vicissitudes as dramatic as any that were to follow.

Finally, about this period a fifth, and wholly different, migration took place. Driven from their mainland homes on the coasts of Asia Minor and Greece, 
and probably from the Egean Islands, by northern foes, these non-Semitic people fell upon Egypt, swarmed overland to Syria, or came by sea to the Palestinian coasts. This displacement may have synchronized with the final destruction of Minoan civilization in Crete. In any event, the Philistines, cast upon the shores of Palestine by it, were not an indigenous race, and it is at least an interesting speculation that they may have been descendants of the master-builders of Knossos. To this invasion the dissolution of the Hittite empire was due. In Egypt the intruders were unsuccessful, for Rameses II defeated them at sea off the Phœnician cities. Having thus secured herself, Egypt withdrew from interference in Palestine for two hundred and seventy-five years.

Evidently, then, Hither Asia had waxed very old ere Israel threw itself upon the southeastern limits of Palestine, so recently attacked on the west by the Philistines. And, be it noted, the entire history to this point, its awe-inspiring scale and its invocation of gods innumerable notwithstanding, has presented no abnormal, non-human, or supranatural features. Is there any reason to suppose that a sixth, and minor, migration of Arab nomads will not remain amenable to ordinary historical causes and racial characteristics? 


\section{The Old Testament}

Having thus tried to realize that Old Testament times form but a fragment of Semitic civilization, to say nothing of ancient civilization as a whole, and that, according to present knowledge, the customary exclusion of this consideration results in a false perspective, with its indefensible exaggeration of an episode, let us turn now to the Hebrews themselves.

Confronted with the history of Israel, we discover at once that a grave disadvantage besets us. To those who have bestowed little or no attention upon the matter, the reason may well occasion profound surprise. In the nature of the case, the records that present the history of Babylonia, Egypt, and Assyria are the veritable originals for the most part. Further, they are often contemporary with the events related. Deeds from the offices of the great Babylonian bankers, the Egibi firm, and of their earlier colleagues, the house of Murashu, at Nippur, are in our hands, signed, sealed, and delivered on the occasions of the transactions which they detail. Besides, we are aware that editing in Babylonia -

"was done with scrupulous care. Where a character was lost in the original text by a fracture of the tablet, the copyist stated the fact, and added whether 
the loss was recent or not. Where the form of the character was uncertain, both the signs which it resembled are giren. Some idea may be formed of the honesty and care with which the Babylonian scribes worked from the fact that the compiler of the Babylonian Chronicle, which contains a synopsis of later Babylonian history, frankly states that he does 'not know' the date of the battle of Khalulê, which was fought between the Babylonians and Sennacherib. The materials at his disposal did not enable him to settle it." 1

On the contrary, if Abraham be chosen as the starting-point, and if he were a contemporary of Hammurabi, Israelitish history runs more than eleven hundred years ere we come upon contemporary records approximately. And, when historical times are reached, the documents reveal interested editing; not, indeed, the childish, vainglorious boasting of some Egyptian regal monuments, but a subtle evaluation, maximizing here, minimizing there, and designed to produce a certain impression about the facts, not to reproduce the facts themselves. Briefly, a theory has been formulated, and by its authority the facts were adjusted. To orercome this prodigious initial difficulty has been one main task of modern scholarship. Small wonder! For, "over a thou-

${ }^{1}$ Babylonians and Assyrians, A. H. Sayce, p. 53. 
sand years separate our earliest Hebrew manuscripts from the date at which the latest of the books contained in them was originally written." 1 Strange irony of fate, not to say strange oversight of an omnipotent God respecting His own special revelation, that the official seals affixed to letters by the bureaucracy of Sargon of Agadè should have come down to us, while documentary evidence of, say, the 'prophecies' of Isaiah is "no earlier than the ninth century after Christ!" 2 The fortunes of these precious works are known more or less .generally from about 270 A.D.; prior to 200 B.C. conjecture reigns, becoming more and more vague as the years recede. What would we not give to-day for any portion of the Old Testament as it left the hands of the writer, especially if he could have shown something of the care bestowed by the Babylonian scribe? So, instead of indestructible monuments, what have we?

"There is one book of books that is generally regarded as the most suitable of all for general and constant reading, the very best book: this is the Bible. Few books, however, prove so conclusively as does this that the bulk of mankind cannot read at all. The so-called Old Testament comprises, as is

${ }^{1}$ Our Bible and the Ancient Manuscripts, Frederick G. Kenyon, p. 35 (3d ed.).

${ }^{2}$ Ibid. 
well known, all that is left to us of the ancient Hebrew literature of a period of 800 years, together with some few books in Greek. It includes writings of the most various value and the most various origin, which have come down to us with text edited comparatively recently, often corrupt and marred in addition by endless copying, writings ascribed as a rule to men who never wrote them, nearly all difficult to understand, and demanding extensive historical knowledge in order to be read with the smallest profit." 1

Yet on this record, and often in ignorance or misapprehension of its nature, scope, and import, many would still have us stake our hope of salvation!

The Old Testament becomes unintelligible inevitably if, as is habitual, one mistake it for a monograph. Evidently it ought to be viewed as a library, the collected and edited remains of a literature originated by a "peculiar people" throughout a millennium. To unravel and systematize its historical relations is therefore an indispensable preliminary to any conclusion about its message and fundamental value. At present we must confine ourselves to a brief survey, directed chiefly to appreciation of the general situation and its results.

At this point it were well to recall that the patri-

${ }^{1}$ Georg Brandes, in the International Quarterly, vol. xii, pp. 278-279 (I906). 
archs are legendary beings; that the story of Abraham's eventual migration to Egypt may be due, possibly, to editorial misconception - the place mentioned may be in the Sinaitic Peninsula, far removed from Egypt; that, as yet, we have no evidence of Israel's sojourn in Goshen; that, in any case, the Israel of David never could have been there, and that, therefore, the popular idea of the Exodus has no foundation in fact. Granted that the 'Exodus' took place about I230 B.C., the remanent literature affords little or no record of events (myth, legend, and song aside) for a period of about four centuries; while the great age of composition falls in the $35^{\circ}$ years between $75^{\circ}$ and 400 B.C., subsequent, that is, to a national consciousness of a special mission, in the interest of which the literature is enlisted, and the more ancient fragments embellished or reconstructed. Needless to say, this transitive, doctrinaire standpoint, were it not so evident, would render evaluation almost impossible. Fortunately, such slight pains have been taken at concealment that it affords positive aid. In other words, the literature could not have come into existence in its present form till after the national consciousness had crystallized, at least in the minds of the leaders. Accordingly, it has proved possible to map the main outlines of a 
most tortuous process. The pivotal date is 62 I B.C., when the Deuteronomic Law was ratified and enforced by Josiah. So, for the present illustrative purpose, it may suffice to consider the literature till Josiah.

By the unobservant manner in which he reads the Bible, the plain man justifies Brandes's assertion quoted above. Even in the English version, the Old Testament bristles with eridences of composite origin, yet few seem to take heed. The contrast between the two creation-myths in Genesis $\mathrm{i}$ and ii can hardly escape notice. But how many of you have observed such points as the following? What is the meaning of the inconsequential stuff in the first four verses of Genesis vi? 'That is, what has been cut out deliberately? Psalm xly stands alone in the psalter; evidently it is a royal epithalamium. In Isaiah a break occurs at the fourth verse of the tenth chapter, and another at the end of the twelfth chapter. In Joshua xix. 47 and Judges i. 34 the same political condition is sketched. The hymn in I Chronicles xvi. 8- 36 is extracted from the one hundred fifth, ninety-sixth, and one hundred sixth Psalms. In Joshua vi two accounts of the fall of the walls of Jericho have been welded; and the same holds true of the story of the Egyptian plagues 
in Genesis vii. I4-xi. 8. In Joshua xv. I3-19, 63; xvi. I-3, Iо; xvii. I-2, 8-I8, we have a representation of the conquest of Canaan by individual prowess; even Joshua himself is the leader of the Joseph clan only, not of a united Israel; that is, the main standpoint of the book as a whole is contradicted. Similarly, though now in a theological as contrasted with a historical context, the sacrificial verses at the end of the exquisite fifty-first Psalm traverse the spirit that has touched the song to such fine issues. Or, to take but one other example, have you ever tried to separate the two self-contained, but mutually exclusive, stories of Joseph's sale into Egypt? (Genesis xxxvii, xxxixxl.) According to one tale, Joseph's brethren hate him, because he has visions which foretell his superiority. When he visits them at the grazings, they decide to kill him. Reuben dissuades them, and they cast him into a disused cistern, whence Reuben expects to rescue him privily. Midianites steal him away, and sell him to Potiphar, the governor of the prison. Here it is his duty to act as attendant upon two privileged prisoners. He tells their dreams for them, and asks them to remember him with Pharaoh, informing the 'butler' that he has been stolen from his homeland. According to the other tale, Joseph's brethren hate him, because he is the favoured son, who has received 
a garment significant of princely rank. When he visits them at the grazings, they decide to kill him. Judah dissuades them, and they sell him to a group of Ishmaelites. The Ishmaelites sell him to an anonymous person in Egypt, who has a wife. For the sake of Joseph's god, Yahwéh, this person prospers. The wife slanders Joseph, and he is thrown into prison, where, thanks once more to Yahwéh, he ingratiates himself with the governor. Plainly, two legends have been united here, and both cannot be true. These examples, then, may serve to indicate the composite character of the documents as they have descended to us. And, when we come to consider the literature before Josiah, this fact assumes paramount importance.

In the first place, the larger portion of the material is anonymous. The authors of the following are known, viz.: Amos, Hosea, Isaiah i-xxxvii (but chapters xii. 2-xiv. 22; xxi. I-IO; xxiv-xxvii; xxxiv-xxxv were written subsequent to Josiah), Nahum, Micah i-vii. 6, Habakkuk, and Zephaniah. For the rest, we are forced to conclude that the documents present the most complex character. Myth and legend in the form of epos, song, hero-saga, fable, proverb, precept, folklore, primitive custom, clan and domestic law, rhapsody, - 
all contribute their respective shares. ${ }^{1}$ Lost collections, like the Book of Jashar and the Book of the Wars of Yahwéh, are quoted. Throughout, evidences of compilation, readjustment, and repeated revision abound. At the same time, it has been discerned, after laborious examination, that these literary phenomena offer no exceptional or unparalleled features. Consequently, historical criticism, in the hands of its most accomplished exponents, has been able to reach certain definite findings. For, all things considered, one can agree that "the battle over the Old Testament is as good as ended." Opinion may, and does, differ about many details; for example, was the ashera a tree or pole, or a goddess? But, on the broad general outline, the conclusions are accepted even by conservative investigators. The cumulative nature of the evidence admits of no other result.

The remainder of the early literature, then, consists, in the main, of three documents, known respectively as the Jahvist, the Elohist, and the Deuteronomist; the last belongs to the period of Josiah. During the exile, a fourth author, the

${ }^{1}$ Students of the Old Testament would do well to compare similar phenomena in the Iliad, e.g., the famous catalogue of ships, the injuries wrought by the gods in bk. v ( $385 \mathrm{f}$.), and the long interpolations from the Corinthiaca in bk. vi. 
Priestly Writer, interposed; and, posterior to the exile, there was a final redaction of the whole material, from a standpoint akin to that of the Priestly Writer. As always, the older records excel in spontaneity. While it cannot be said that "J" (the document which uses the name Yahwéh for God) and "E" (which employs the term "Elohim") accord completely in outlook, they do not fall under the domination of an claborate theory, like the Priestly Writer. More than aught else, they regard religion as a natural incident of human life, whereas their successors suffer from self-consciousness of its divine institution, and spread through exclusive channels of revelation. Besides, the redactors attain to authorship in the current sense of this term; their predecessors are rather reporters (of story-tellers and rhapsodes), or collectors of material that was still fluid in oral tradition. Thus, it is easy to distinguish the Deuteronomist and the Priestly Writer from "J" and " $E$," difficult to separate " $J$ " from "E," sometimes impracticable.

The material grouped in these two earliest documents, which may be said to date from 850 to 750 B.c., in their first unified forms respectively, often goes behind them, refers to very different situations, of which few accurate details are now recoverable, and 
is certainly of most unequal value. But, on the whole, and throughout, we find ourselves in an atmosphere controlled by imagination. Poetry, not historical truth, dictates the norms. Not till Israel had actually won foothold in Canaan, can it be said that history tends to replace tradition. For example, the stories of the Creation and the Flood are myths, pure and simple; moreover, they pertain to the Semitic race, not to the Hebrew moiety of it. In the passage containing Lamech's 'Song of the Sword' (Gen. iv. I9 f.) we have obviously a very primitive tale, and a fragment of admirable poetry. Lamech's sons are represented as the fathers of all nomadic shepherds, musicians, and workers in iron. How this could be, if all perished in the Flood, except Noah, the farmer, the writer takes no notice. Attracted by the poetry, he is satisfied to adopt the folk tale. The 'Song of the Well' (Num. xxi. I 7 ) introduces another ancient fragment, which a people living in settled society could scarcely appreciate. Of a different character is the 'Triumph Song' of Deborah and Barak (Judges $v$ ). Here we have a pxan of victory that may well revert to a historical occurrence during the first invasion of Canaan. Of the same kind are David's 'Elegies' over Saul and Jonathan (2 Sam.i. I7 f.) and on Abner (2 Sam. iii. 33). They belong 
quite plainly to the class of poems made effective by access of emotion, that is, they come of flesh and blood. Other ancient documents may be noted in Jotham's 'Fable' (Judges ix); Samson's 'Riddles' (Judges xiv. I4; Xv. I6); David's decision regarding the spoil (I Sam. xxx. 24); the 'Proverbs' in I Sam. X. II, and xxiv. I3. Of still another sort are the cycles of stories (often exhibiting traces of rearrangement and interpolation) relating to the patriarchs, to Abraham, Jacob, Joseph, and so on; or the herotales, about Samson and the youthful David, for instance. The former limn types, constructed from tribes or clans; the latter emphasize achievements of men whose lives fell within the penumbra of the historical period, but set them in a legendary, almost epic, perspective. While, again, the fragment in Genesis vi. I-4, introducing the Titans (Nephilim), harks back to a stage of religion so remote that the narrator has lost all sense of its implications. ${ }^{1}$ This example may serve as a warning, to be kept in mind

${ }^{1}$ Something of the same kind may be traced in that complex document, the "Blessing of Jacob" (Genesis xlix), if, as some think, it is reminiscent of a religion in which the signs of the zodiac played a prominent part. (Joseph is Sagittarius, Dan is Scorpio, and so on). Even if this be tenable, it is perfectly obvious that the writer knew nothing about it, never had such possibilities in mind. 
constantly, that the documents under consideration often tell very little, because their authors do not themselves appreciate their material. 'Thus Ishmael, Noab, Rachel, Leah,' Hagar, and so forth, are not persons, but the names of clans or clistricts. Similarly, Asher, Gad, Milcah, Sarah, and, probably, Laban, are names, not of men and women, but of gods and goddesses. Of course this amounts to a statement that the documents, instead of furnishing a straightforward history, raise numerous and complex problems. Thus, for instance, it has been suggested that the story of Jacob's encounter with the angel is a very faint reminiscence of the Nephilim. Jacob was a Titan once, and could do titanic things. Now he has become a mere man, but with this survival from his mythical past which, naturally, his present biographer fails to comprehend. However this may be, it is quite evident that the literature before Josiah offers legend chiefly; and the historical parts, post-dating Israel's settlement in Canaan, and going back scarcely beyond Saul or David, have been subjected to a process of idealiza-

${ }^{1}$ As in the case cited in the previous note, Rachel and Leah suggest a totemism from which meaning has faded utterly for the writer. In other words, we are at a late stage in the development even of Semitic religion, to say nothing of universal religion. 
tion and reconstruction; so, they too contain a large imaginative factor.

Accordingly, the conclusion of the matter, as concerns the early literature, may be summed up as follows. Prior to the Exodus we know nothing; and the actors mentioned must be viewed as legendary figures. The sojourn in Egypt, the Exodus, and the migrations in the wilderness were all subjects of a persistent tradition in Israel. Very possibly they may have foundation in fact; if so, what did happen differed in essentials from much alleged in the narrative. Nevertheless, the story, as we have it, by the light it throws upon Semitic customs, helps us to arrive at a sober view of the probable events. Even Moses must be taken, in great part, as a legendary, in some part, as a mythical, figure. His career and acts conform to certain well-understood social and religious characteristics of Semitic nomad clans, and, to this extent, can be rediscovered and systematized. $^{1}$ Beyond this general setting we possess no real knowledge of Moses, who was, not a man, but an idealized epitome thrown back by a later age upon a supposititious heroic past, its own creation.

'It is a commonplace that, for centuries after Moses' alleged date, the Hebrews shared the polytheism of adjacent "Semitic heathenism." Cf. A Sketch of Semitic Origins, George A. Barton. 
And after the conquest of Canaan had begun, and : ended, so far, the same traits persist. David, a brigand sheik originally, is clothed upon imaginatively till he actually becomes a vicegerent of Yahwéh. Or, in his relation of the narrative, the sympathies of the author, with the northern or southern kingdom, as the case may be, transform the circumstances. Briefly, as in ancient literature universally, so here, nobody knows anything of origins, and, when history begins, the writers evince elementary conscience for accuracy. Subjective views as to what the facts ought to have been render an objective report impossible. In the circumstances, nothing else could be anticipated; and Israel is no exception to the normal human rule, nay, affords another, and very impressive, proof.

Nothing in the Old Testament has fallen so hopelessly upon the evil fate of false representation as the prophetic literature. The prophets, from Elijah, and even Samuel, to the author of Daniel, were riven from their historical position, deported to a Hellenistic provenance, and tricked out in every device of unlicenced phantasy. As a matter of fact, the Hebrew prophet was a man who could discern the signs of the times, rate temporal events at their value $s u b$ specie aternitatis, and speak to his genera- 
tion accordingly. There is no doubt that he beliered himself accredited to deliver a special message; but he spoke as he knew and, very specially, as he felt, in a certain contingency. Thus his work always faced two ways. On the one hand, he had a clear eye for the contemporary circumstances of his people; on the other, an intuition for the significance of religion, as affected by these circumstances, and as capable of reaction upon them. Consequently, the prophetic books are of inestimable price for comprehension at once of the civil history and the religious evolution of the Hebrews in these days. By this relation they must be judged and interpreted.

After Solomon's death, the Hebrew empire underwent immediate dissolution; the division into two kingdoms, Israel in the north, and Judah in the south, dates from 937 B.c. This event wrought momentous results in two ways. It undermined the political strength of the Hebrews once for all, and, by the isolation of the northern kingdom from the incipient religious primacy of Jerusalem, originated conditions favourable to the continuance of heathenism within Israel itself. Not long after their foundation, both kingdoms were plundered by the powerful Pharaoh Shishak, Judah suffering more severely. This, with the growth of commerce 
in Israel, led to the dominance of the northern kingdom, and Judah made alliance with Damascus. Meanwhile a new political situation was eventuating in the Euphrates-Tigris region, where the power of Assyria was maturing surely. Ashurnatsirpal III had felt strong enough to attack the Aramæans on the head waters of the Euphrates, and, in 876 , took Carchemish, the capital of the attenuated Hittite kingdom. This was contemporaneous with the rise of the house of Omri to ascendancy in Israel, when Samaria became the capital; and Ahab, the monarch of this dynasty notorious unjustly to us, reigned from 874 B.c. Under this house Judah was reduced to vassalage. In the interval, the Assyrians, under Shalmaneser II, had been engaged with Damascus, which headed a coalition against them. Ahab contributed no less than 2000 chariots and Io,ooo men. After the indecisive battle of Qarqar, in $85^{2}$, he loosed himself from this league, and, about the same period, the advance guard of another great migration from Arabia (the Nabatæan) instilled fresh ambition into Edom and Moab. This is the era in which the prophet Elijah rebukes the idolatry of Israel, and Elisha proves himself a dangerous agitator. Thrice Shalmaneser attempted to break Damascus, and failed; while Judah, weakened by 
the drain of men and treasure required from a vassal state, fell a prey to a Philistine-Cushite alliance, thus affording Mesha, ling of Moab, opportunity to regain independence. Instigated by Elisha, Jehu murdered the whole house of Omri, except young Joash, and, by 842 , was tributary to Assyria. But, occupied with the Armenians nearer home, Assyria retired for a time, and, in Sio, Joash is a vassal of Damascus. Again the Assyrian advanced, Damascus yielded tribute, and "the Lord gave Israel a saviour, so that they went out from under the hands of the Syrians" (2 Kings xiii. 5). These centuries of unbroken confusion, of thrust and counterthrust, could not have been favourable to high internal development. It is not surprising, then, that written prophecy does not arise till later, till a time, that is, when the Hebrews could rest long enough to consider their position. From 799 B.c. events bear less harshly upon the twin kingdoms. Jehoash is strong enough to worst Benhadad II, and Amaziah to take the Edomite capital. By 784 Jeroboam II and Uzziah, both energetic and successful rulers, have come to the thrones of Israel and Judah respectively. The two countries now attain a prosperity unexampled since the spacious days of David and Solomon. Damascus has been broken, and Assyria is too engrossed else- 
where to interiere. Jus: at this juncture the full tide o: Hebrew prophecy begins io How.

Amos makes his siarling and disconcerting appearance. io wam the people that lururious, easygoing aimos: materialistic worin cannot please Yahwéh. and must umble to disaster. The God is a just God. who hates eril. lores good. and wills to establish judgement within the gate. Forget this, his fundamental character. and you prove yourseli a dupe to the mere external show of stability. The real fact is tha: Iahwéh reigns wherever justice runs, and admits no special obligation. even to Israel, if injustice flourish within the border. Thus, the monotheistic ver attains cennite expression only at this late day. The idea received further development in the message of Hosea. for whom God is love, and from whose pathetic conviction the future foith of Israel sprouts. Jeroboam II died in $7+1$ : in the short space of eight months, Zechariah and Shallum were murdered and Menahem set on the thronea barbarous despot. Israel was rent by faction, and Menahem became tributary to Assyria. Meanwhile Judah prospered under Jotham. Faction wrought further anarchy in Israel; Menahem's son. Pekahiah. was murdered. and Pekah, an assyrophobe, ruled. He leagued himself with Damascus 
against Tiglathpileser III, and tried to force Judah into the alliance. Refusing, Judah was invaded, and, brought to dire straits by the rebellion of Edom and an invasion of the Philistines, appealed to Assyria. Tiglathpileser advanced to the rescue, and plundered Israel. Pekah was murdered by his own people, and Hoshea, who succeeded, accepted Assyrian suzerainty. In 732 Tiglathpileser took Damascus, deported its inhabitants, and Palestine enjoyed peace for six years. On the accession of Shalmaneser IV, in 727 , Israel joined a Syrian league in revolt, and, in 722 , the northern kingdom came to an end, on the fall of Samaria, and the deportation of the directing classes. Israel was now an Assyrian province, Judah a vassal state. These were the days of the mighty Sargon and of the mightier Isaiah.

Isaiah's whole outlook was conditioned by the contemporary political situation. Israel had become a memory now, and Judah might be snuffed out unceremoniously at any moment. To comprehend this astounding shock to Hebrew expectation and reminiscence, a new philosophy of history was needed; to weather temporal danger with a whole skin demanded a practical policy. Isaiah furnished both. Stated in a word, the former pirots on the idea that judgement is not the goal, but the prerequisite of 
salvation. This, as Isaiah thought, the people must be forced to grasp, so that a remnant, if no more, might be preserved to witness for essential spiritual truth. On the practical side, Assyria is to him but a tool in the hands of the Almighty; therefore, with Assyria Judah must keep strict faith. Mount Zion, where Yahwéh dwelleth, cannot be violated, must stay inviolable. Heedless of the prophet, Hezekiah listened to Egypt. In $70 \mathrm{I}$ Sennacherib descended with a veteran army, overwhelmed the Egyptians, and decimated Judah, deporting more than 200,000 souls. Nevertheless, Jerusalem stood, and Isaiah was justified to such an extent that Hezekiah purified the worship of the temple from much idolatrous admixture. Their contemporary, Micah, an oldtime idealist of the Amos type, poured the awful vials of his wrath upon this same idolatry, especially upon the social conditions wherein it rooted. Then prophecy fell upon silence. The Assyrian guarantee was to suffice for a little, and the Assyrian gods!

In the brilliant era of Esarhaddon and Assurbanipal, when Assyria lorded it from the mountains of Van to the Nile, Judah could hardly fail to be a mere enclave in the magnificent empire. And, from 686 B.C., when Manasseh came to the throne, it proved so. The gods of Assyria became the gods of the Hebrew 
remnant, and prophecy, being a plain nuisance, was stamped out fiercely. The sixth and seventh chapters of Micah refer to this leaden period. All external supports and encumbrances having vanished, the writer appeals to the still, small voice, lending prophecy the purest expression yet attained. "He hath showed thee, O man, what is good; and what doth the Lord require of thee, but to do justly, and to love mercy, and to walk humbly with thy God?" (vi. 8). No Hebrew speaks here to a backsliding folk, but a man utters an imperishable thing to humanity. That world has passed long, long ago, with the pride and the lust thereof, leaving scarce a wrack behind, but these words ring down the ages, as absolutely true to-day as in the sad hours of their first utterance. Never was a man's sense for ultimate values to be vindicated more thoroughly. Assyria's doom dogged her already. Another widespread displacement was in process, this time in Central Asia - the Scythian horsemen had saddled. The Dies Irae of Zephaniah (i. I4 f.) neared dawn, judgement had been entered against Manasseh's line and sin. Nahum and Habakkuk divine the catastrophe of proud, cruel Assyria. "The burden of Nineveh" (Nah. i. I); "shall he not spare to slay the nations continually?" (Hab. i. I7.) Jeremiah, the inter- 
cessor with Yahwéh for his own erring people, also appears in the land. And by 620 B.c. the Scythians have swept past Nineveh, and swarmed into the littoral of Palestine.

Manasseh had died in 647, and after Amon's murder, at the end of a two years' reign, the child Josiah had been placed on the throne. In his minority, under the assyrophile court clique, idolatry went from bad to worse. At length the pietistic party ventured to send a book of the law, discovered in the temple, to the king, now a youth of twenty-four, whom it moved profoundly. ${ }^{1}$ This document, our Deuteronomy, marked a fresh epoch in Hebrew religion. A new worship, centralized at Jerusalem, and a new god almost, who bore no natural relation to this present evil world, were introduced. Religion was evaporated from its intimate union with the body of the civil state, and set apart as a holy essence. A point of view had come to clear consciousness, whence the entire past of Israel could be considered and reinterpreted: lights could be heightened, shadows deepened, according to a firmly set belief in a peculiar, divine purpose. The prophet had blazed

${ }^{1}$ His reference of the matter to the spae-wife Huldah is typical of the conceptions of science at that time (cf. 2 Kings xxii. I 2, 2 Chronicles xxxiv. 20 f.). 
the way for the priest. Issues most momentous for the preservation of the religion of Isracl, no matter what temporal mischances might befall, were settled at nigh a stroke. With this reversal, an outgrowth of Assyrian success, and of a reaction against heathen customs when the political power of the conqueror declined, the literature to Josiah ends.

Josiah's new-born devotion to Yahwéh, coincident with the removal of the Assyrian yoke, profited him little. The Pharaoh Necho invaded the land; the righteous king met defeat and death in another fight at Megiddo, that cockpit of Palestine. The last scene in this act of the drama ended in even worse disaster; for the Chaldæan, Nebuchadnezzar, now monarch of the new Babylonian empire which succeeded Assyria, took Jerusalem by storm, in 586 B.c., and on three several occasions the flower of the population was deported to the Euphrates-Tigris valley, there to learn much from Babylonian and Persian civilization.

It seems superfluous to enforce the conclusion that, as a result of the historico-critical method, the traditional conceptions of the "mission of Israel," of the nature of the Old Testament, and of the relation of Jewish religion to Christianity, 
"Are melted into air, into thin air...

.. . like the baseless fabric of " a "vision."

Doubtless, it is still possible to flout the critic, and say, "he's of a most facinerious spirit." But, whatever his reputed atrocities, names neither hurt, nor alter the facts. One of the most spiritually minded of living scholars, a man persuaded slowly, by stress of evidence, to pass from supposition to knowledge, has placed himself on record as follows:-

"And now I must make an admission to you, which it is hard for me to make, but which is my fullest scientific conviction, based upon the most cogent grounds, that in the sense in which the historian speaks of "knowing," we know absolutely nothing about Moses. All original records are missing; we have not received a line, not even a word, from Moses himself, or from any of his contemporaries: even the celebrated Ten Commandments are not from him, but, as can be proved, were written in the first half of the seventh century, between 700 and 650 B.c. The oldest accounts we have of Moses are five hundred years later than his time." 1

This, and much like it, being admitted unavoidably, the keystone has fallen from the arch of the impressive and imperious theological construction: we have not "Moses to father." In these circumstances,

${ }^{1}$ C. H. Cornill, in The Prophets of Israel, p. I7 (Eng. trans.). 
but a single moral need be pointed. The ignorant and the dogmatic, be they laity or clergy, cannot learn too soon that, as matters stand, scholarship) alone is able to reply to scholarship. A complete transformation has overtaken us, and the sole course is to face the judgement without reservation. This at least spells sincerity - always a firm ally of safety when the final reckoning arrives.

In the nature of the case, I have been able to furnish only the merest impressionistic sketch of the historico-critical attitude to the Old Testament. Nevertheless, it suffices to convey a very definite set of inferences.

NoTE.- The following works are readily available for readers of English who wish to pursue the subject farther. A History of Egypt, J. H. Breasted; History of Babylonia and Assyria, H. Winckler and J. A. Craig; The Early History of Syria and Palestine, L. B. Paton; An Introduction to the Literature of the Old Testament, S. R. Driver (Scribner, New York); The Genesis of Genesis, B. W. Bacon; Triple Tradition of the Exodus, B. W. Bacon (Macmillan Co., New York); The Documents of the Hexateuch (two vols.), W. E. Addis (David Nutt, London); The Legends of Genesis, H. Gunkel (Open Court Co., Chicago); the Old Testament Articles in the Encyclopæria Biblica (Macmillan Co.), or in Hastings' Dictionary of the Bible (Scribner). 


\section{LECTURE IV}

\section{HUMILIATION IN THE MIDST}

Divergent opinions on minor points, and on several important internal problems, such, for example, as the origin and organization of the Psalter, admitted, it may be affirmed, fairly enough, that scholars agree on their solution of the Old Testament riddle. The historico-critical movement has triumphed all along the line here. Still, even so, many, especially in English-speaking lands, fondle the idea that New Testament study walks the old paths, and that thus, criticism notwithstanding, the citadel of dogmatic Christianity maintains itself inviolable. But when one comes to inquire what the leaders of the historico-critical movement have to record about the Christian sacred books, one discovers very soon that this confidence lacks solid foundation. So much so that "the inhabitant of Maroth" may well wait "anxiously for good: because evil is come down ... unto the gate of Jerusalem." Moreover, his perplexity must increase when he reflects upon a fact that events often conspire to hide from him. Doubtless he has heard, in a general way, of the "attack on 
the New Testament," and his teachers, true to a sadly mistaken sense of duty, have informed him that all this amounts to 'scepticism.' It were pertinent, therefore, to set in the forefront that critical discussion of the New Testament is no more identical with 'scepticism' to-day than the conclusions of the scientific consciousness are indistinguishable from 'materialism.' For the main volume of this inquiry proceeds from Christian scholars, from members of the Christian ministry as a rule. These investigators seek a more adequate knowledge of the growth and development of faith in Christ. Above all, they desire to strip our religion of accretions from nonChristian sources, and to trace the transformations wrought by this admixture. In addition, we must call to mind that the natural concentration of New Testament study in the hands of professing, and often official, Christians, has resulted in a situation far different from 'scepticism,' or anything that, in common justice, can be termed 'scepticism.' Indeed, the chief preliminary consideration issues from this very circumstance.

\section{The New Testament}

The Old Testament contains the socio-religious record of an alien race, of a people whose faith is not 
I42 MODERN THOUGHT AND THE CRISIS IN BELIEF

ours, who continue strangers to several transitive principles that permeate the Christian consciousness through and through. Accordingly, it may be treated with a certain independence and objectivity possible with respect to the New Testament only at the end of long, tentative trial, involving bitter conflict. Moreover, in the one case far more easily than in the other, the scholar rids himself of the iteration of the still, small roice that whispers, What is left? With incomparably less inhibition, he finds himself able to ask, What have we here? As a consequence, the historico-critical account of the Old Testament possesses a clear outline, and commands a general assent by no means reached as yet for the New. Particularly is this true about those matters of apparent detail which in sum, despite their subordinate character, affect the larger outlook deeply. An Episcopalian, just because he is an Episcopalian; a Presbyterian, just because he is a Presbyterian; a Baptist, just because he is a Baptist; a Roman Catholic, just because he is a Roman Catholic, approaches the New Testament with special prepossessions on special points. Similar considerations touch Old Testament inquiry much less; on the contrary, they conspire to prejudge interpretation of the New. Besides, all confessional Christians, so 
far as their "written constitutions" go, agree to view the New Testament from a doctrinal rather than a historical standpoint. Needless to say, this fact has wielded, and still wields, incalculable influence. Thus, for many causes that we cannot expect to escape yet awhile, the Christian books must remain subjects of controversy; differences born of sentiment must occupy the foreground, very likely out of proportion to their primary importance; views upon matters of fact must continue to be tinctured with conjectural elements.

No better illustration of these obvious conditions could be wished than the reception accorded, eleven years ago, to Harnack's famous preface, ${ }^{1}$ where he affirmed that criticism was moving back gradually to "traditional standpoints." Excitement electrified many; one heard on every side that Strauss and Tübingen had been put to ruinous flight, that the position had been saved for the entire array of ecclesiastical dogma. On the other hand, one did not hear that, on close examination in detail, the conclusions of the Berlin master agreed with those of criticism on nigh all points of fundamental importance. For him, as for the "evicted" critics, the

${ }^{1}$ Prefixed to vol. i, part ii, of his Chronologie der altchrist.lichen Literatur. 
author of the First Gospel was unknown; the authorship of the Third was "purely a problem of internal criticism," and therefore a matter of opinion more or less; the Apostle John was not the author of the Fourth Gospel, and so on. Commenting on this, one of the sanest among New Testament critics says: "To me, however, this new cult for the 'tradition' - by which, as a matter of fact, Harnack understands something quite different from the 'tradition' of Zahn ${ }^{1}$ and his followers - seems quite as questionable as the earlier prejudice against it." 2 And Harnack himself supports this contention in the preface to a recent study. "I saw myself brought forward as a witness to testify that in historical criticism we are returning to the conservative point of view. I am not responsible for this misapprehension of my position. . . . Let me, therefore, express now my absolute conviction that historical criticism teaches us ever more clearly that many traditional positions are untenable and must give place to new and startling discoveries." 3 We may conclude, accordingly, that although, thanks to peculiar and irremovable circumstances besetting the inquiry,

1 The most prominent conservative critic.

${ }^{2}$ An Introduction to the New Testament, A. Jülicher, p. 27.

${ }^{3}$ Preface to Lukas der Arzt (written in May, 1906). 
some New Testament questions, particularly as they pertain to specialized problems, stand in controversy, a partial consensus begins to emerge. Without condescending upon extreme positions, let us try to understand what this conveys.

In the first place, and generally, the New Testament cannot be treated as a book. It contains a literature composel at intervals during a period of I30 years approximately. Twenty-seven contributions, of the most varied character, occur in it. We know that they were written by ten or twelve persons at the lowest calculation; but how many others had a hand in the library as it cxists now we have no present means of determining. It is apposite to recall in this connexion, for example, that the canon of four Gospels was probably substituted for one Gospel under suspicious circumstances, and that one document, in any case, was subjected to mutilation for reasons that had nothing to do with its historical value. As they stand in our English Bible, the New Testament writings disregard chronological sequence, and this in itself has produced numerous misconceptions. Of course, interpolations, additions, and corrections are nowhere indicated, so that he who runs may read. It is clear, however, that, taking 46 A.D. as an upper, and I75 A.D. as a lower, limit, the con- 
stituent portions were produced much in the same way as other human documents. They reflect one religious movement among many, but a movement peculiar on account of its intensity, its missionary spirit, and its powerful syncretist tendency; nevertheless, a movement that originated and spread under historical conditions characteristic of the Roman Empire at the time, especially as they related (I) to the region of Asia Minor, including Palestine, (2) to the Jewish Diaspora, (3) to the promiscuous religious consciousness, marked by elements drawn from Hellenistic thought, Jewish theocracy, and Oriental apocalyptic vision, all interacting. The entire temper of the period, especially in its Semitic and Oriental qualities, is so foreign to the ethos of Western peoples that, more than likely, many phenomena must elude our grasp always. Nevertheless, such light as is possible can break through in one way only. We must study the Roman imperial polity, religion, and local government, Hellenistic ideas, the Oriental gnostic spirit, the unique position of the Jewish race, and the whole social situation, primarily as moulded by slavery and by the intermixture of ancient cultures, if we would realize, even faintly, the remarkable flurry of events whence the books arose. Written by men in a world of men, they are 
tractable to explanation as a supremely human attempt to alter or disprove, to destroy or understand, some supernal things of life as it seemed then. What we know of the epoch, what we can ascertain by historical and linguistic analysis, or by chronological research, serves here, as elsewhere, to reduce the conglomerate facts to dynamic order.

Critically viewed, then, the New Testament originated in what may be pictured as three great waves of production. In each successive sweep it is possible to discern elements that preserve continuous identity, and thus to elicit the primitive tradition that nucleated after the appalling disaster of the Crucifixion. At the same time, civilization seethed so in the chief age of composition that alterations of standpoint, and even some of their causes, can be detected. Contrasts in the circumstances and characters, in the ability, training, and associations of the individual authors count for much. And, very plainly, the migration of the new teaching, first, from its home in Galilee to Jerusalem, and then from its Judaistic limits into the monstrous whirlpool of RomanHellenistic culture, wrought profoundly. IVe must envisage the possibilities, latent amid these emigrations, in some such way as we think of the very subtle variations that overtook the English ethos, first, in 
old New England, then in the broad United States. The resultant differences, that is, pirot upon a contrasted manner of approach to problems which themselves undergo no total change. But, elusive as they are, in the modern instance, we know well enough how to set about an explanation. To this procedure the ancient world is amenable, mutatis mutandis, and to no other.

Accordingly, pursuant to this method, the first period of Christian authorship dates from the earliest Letters of Paul (Galatians, 46 A.D. $)^{1}$ to the destruction of Jerusalem by Titus in 70 A.D. Within these twenty to twenty-five years some documents of vast moment for the Christian consciousness came to birth. Plainly, the Pauline writings form by far the most important group. In the present state of knowledge, I understand it to be as sure as assurance can go regarding such matters, that the four major Epistles (Romans, Galatians, I and 2 Corinthians) belong to this era, and that the other Letters, except the Pastorals, Ephesians, part of Colossians, and 2 Thessalonians are to be attributed to Paul. To this view some scholars would demur. ${ }^{2}$

${ }^{1}$ Of course, 46 is extravagantly early for Galatians; 50-54 would cover the usual datings.

${ }^{2}$ It does not seem to me that the views of van Manen, Steck, and Professor Smith, of Tulane University, can be entertained seriously. 
So far as I am able to judge, many questions concerning the Pauline documents must be regarded as sub judice. To this time also one may assign the collection of Sayings of Jesus, used by the Synoptists, especially by the author of our Gospel of Mathew. If the writer of the Acts of the Apostles enjoyed documentary sources, - a problem still disputed hotly, - then his oldest source, the so-called "We" document (xvi. IO-I7; xx. 4-15; xxi. I-18; xxvii. I-xxviii. I6), must be referred to this period. Finally, the Jewish apocalypses, rooted in ancient and obscure eschatological saga of the Semites, ${ }^{1}$ used by the author of the Revelation, such, for example, as the astounding allegory reproduced in chapter xii (cf. xi-xiii; xvii-xviii), were composed, in all likelihood, before the final cataclysm at the holy city.

The second period dates from the fall of Jerusalem to (roughly) the death of Nerra, in gS A.D. Like the first, it produced documents of the utmost moment. To this time belong the Synoptic Gospels. Mark came almost immediately after the victory of Titus; Luke is dependent upon Mark; while

${ }^{1}$ So great is the difficulty of this subject that eminent scholars, like Dietrich, Gunkel, Spitta, Eduard Meyer, and W. Bousset, have been able to effect little more than a beginning of interpretation: dogmatic exegesis is out of the question. 
Matthew, which has been edited more than once, prorides an account palatable to all Christians, and the additions that enrich it represent a late stratum. ${ }^{1}$ But, in any case, redaction, interpolation, and excision aside, the general outline of the books, as we have them, was settled during this generation, and especially the ideas that dominated their composition had crystallized. The literature of this epoch includes also the work of one of the three great theologians of the New Testament - the Epistle to the Hebrews. The authorship remains an insoluble problem; I am unable to see how it is possible to overcome objections to the current opinion which connects the Letter with the name of Barnabas.

${ }^{1}$ E.g. i-ii; iv. I4-16; xiv; xvi-xvii; xxi. $2-5$; xxvii. 3-10; xxvii. 62-xxviii. 20. Although I am without shadow of title to express an 'expert' opinion upon the Synoptic problem, I think that an unprejudiced man, who has read the literature carefully, may come to the following conclusions, which I record with all diffidence. It seems to me, on these Gospels, as we have them, that (r) Mark is the objective source of Matthew and Luke; (2) Matthew and Luke presuppose other documentary sources, possibly unknown to Mark, but how these ought to be rated or described precisely I find myself quite unable to say; (3) nevertheless, there is a long and tangled history prior to Mark, in which Palestinian and Pauline influences interact; (4) Luke did not use Matthew as a source, nor Matthew Luke; (5) Matthew and Luke were affected by streams of tradition in the Christian community that differed in some particulars; (6) all the Synoptics have been worked over - Mark like the o hers. 
Another remarkable document of this time is the Revelation of St. John the Divine. It offers a recension of Jewish apocalyptic sources, brilliantly claborated; the authorship cannot be determined with any certainty. All we can say is that probably John the Apostle did not compose it. ${ }^{1}$ 'The Acts of the Apostles, which still presents in many respects one of the enigmas of the New Testament, must also be assigned to these years. Perhaps it belongs to the reign of Domitian $(8 \mathrm{I}-96)$, while, on the other hand, it may date after the death of Nerva, and be referable, accordingly, to the first decade of Trajan. In any case, these last years furnish I Peter.

The final period, from the accession of Trajan till, say, Marcus Aurelius's assumption of sole power (I6I A.D.), provides one document of the first magnitude - the Fourth Gospel. In my humble judgement, this must be accounted, for several reasons, the pearl of great price of the New Testament. As in the case of its lesser companion, Hebrews, the question of authorship has baffled investigation. Scholars are agreed, however, that it cannot be assigned to John the Apostle. And one may as well

${ }^{1}$ This is widely disputed still; I give my own impression of the evidence. 
I52 MODERN THOUGHT AND THE CRISIS IN BELIEF mention, in passing, that this is an immense gain. For, if the two companions of Jesus, Mark (through Peter) and John, had furnished such utterly irreconcilable accounts of the Master, - contrast the Sermon on the Mount with the Johannine discourses,--it would be impossible for us to determine what manner of man he ${ }^{1}$ was in his habit upon earth. Before the year I 20 A.D. come the Epistles of John, followed by Jude, and the Pastoral Epistles ( $\mathrm{I}$ and 2 Timothy, and Titus). The latest books in the New Testament canon are the Letter of James, and 2 Peter, which may bring us down as far as I 50, or even I75, A.D. I may add that, on the whole, this summary tends in the conservative direction, as critical opinion now goes.

The most careless reader of even the English version cannot fail to observe that extraordinary contrasts pervade this literature. The Revelation and Mark move literally in dissimilar universes. The Acts and Hebrews are determined by motives of the most diverse nature. And, for readers of Greek, what a difference rules the verbal habit of the two great anonymous books, Hebrews

${ }^{1}$ Perhaps I should indicate at this point that I distinguish betwien Jesus, who was a historical figure, and Christ, Who is metahis.torical. 
and the Revelation. Nay, more, these contrasts, appearing on the surface, as they do, are nothing to the profounder appositions traceable to general perspectivc, literary facility, spiritual discernment, and regnant personal tendency. And, in every case, these last constitute main factors in the reasons why the books came to be written at all. Notwithstanding, it scems practicable to group the stars of the first magnitude by reference to the contemporary condition of the Christian atmosphere.

When we approach a literature from the side of strict history, the question of convergent, formative influences always commands paramount attention. To understand a book, we must know something of the forces that played around and upon its author. Nor is the reason far to seek. A writer never sits down to record everything - the task transcends possibility. Of necessity, his views and conclusions are formulated in synoptic fashion. He picks and chooses, not indeed to induce a specious effect, but because he cannot proceed in any other way. The crowded, insignificant details of human life must not be permitted to swamp the narrative; the mere surge of them would drown affairs of real moment. So, without exception, a meritorious writer takes for granted that his public shares a common perspective. 
He lets the reader perform his part, anticipates this ability in him. Of course, many fail to realize this, because unaccustomed to reflect upon such matters. But an elementary acquaintance with classical literature, for example, suffices to bring it home forcibly. We cannot appreciate the comedies of Aristophanes just as the Athenian audience did; - we find it difficult to make allowance, in Herodotus, for the pervasive conception of a working Nemesis; we miss not a little of the verisimilitude of the speeches in Thucydides; many details concerning Cæsar's army continue to elude us; it demands careful study to realize the socio-political atmosphere breathed by Tacitus. Nay, the same holds true of literature that stands comparatively near. A novel like Vernon Lee's "Miss Brown," a play like "The Colonel," presented so cleverly by Edgar Bruce, presuppose the so-called æsthetic craze in England thirty years ago; and we must refresh our memories by reference to Gilbert and Sullivan's "Patience," if we would enter into the situation. Be they great or small, literary products, having the slightest pretension to significance, require us to remember this.

The New Testament writings form no exception to the rule. When, for instance, Mark says, "And they compel one passing by, Simon of Cyrene, com- 
ing from the country, the father of Alexander and Rufus, to go" (Xv. 2I), it is evident he assumes that his readers will recognize these personal references - this local and contemporary knowledge fails us entirely. Recalling, then, that all authors content themselves with hints and suggestions respecting affairs familiar in their time, we find that the New Testament, taken as a whole, presupposes two audiences, and therefore two circles of origin. Followers of Jesus constituted both, but their several temporal circumstances happened to be different. The smaller, more highly organized, and less cosmopolitan group had its centre in Palestine, and clung to Jerusalem as the foreordained city of God. It was clominated, accordingly, by ideas current among the Jews in these days, and by a conviction that, in the new religious community, the long travail of Israel had attained finality at last - the true Messiah had appeared, lived, paid the penalty, and ascended, as the Scriptures prophesied. Therefore these Scriptures, above all, the Mosaic Law, were held of peculiar moment in the plan of salvation. Apocalyptic expectations abounded, and the Messiah might return at any hour, to execute his judgement, to claim his kingdom, to inaugurate his world-rule. Here we find an imperium in imperio, as it were; a special 
phenomenon, aside from Roman-Hellenistic civilization, concerned to preserve its own traits so far as possible, eren under the heel of heathen might.

But, emphasize the Jewish purview as one may, the fact remains that Roman-Hellenistic culture was the universal feature of the age - the very disciples of the innermost circle answered to Greek names. Antioch and Ephesus, Rome and Alexandria, typified influences that could not be excluded or stayed. So, as Jesus himself journeyed into Phœnicia, his disciples fared forth amid the perplexing civilization of the wonderful empire, and to momentous consequence. With all the will in the world, the Gentile could not treat the Scriptures or the Law as if he were a Jew "to the manner born." His apprehension of the anticipated apocalypse could not but take a course peculiar to itself. His appreciation of the significance to be attached to Messiah's career and continued spiritual presence was coloured, inevitably, by associations drawn from Græco-Roman or Oriental traditions in culture. More than aught else, perhaps, the means and methods of his education, reaching back to the age of the Sophists, and transmitted through a series of glorious intellectual achievements, destined him to react upon the plastic faith in very distinctive style. Similarly, a Jew resident 
in Palestine, by the mere fact of his Aramxic dialect, would diverge widely from a Greek-speaking Gentile. His direct heritage from the spiritual past of his folk, his conventional interpretation of the Scriptures, his inherent unity with ancient social custom and moral observance, his racial pride and expectation, surrounded him on all sides, and marked out the ofd paths wherein he ought to stand fast. Thus, he too caught up the new faith in a way manifestly his own. Now, the New Testament writers presuppose these contrasted, yet in a sense complementary, ethnic perspectives. The authors assume the aptness which would be evinced naturally by readers moulded in one or the other environment. By no means "all things to all men," they assuredly "write up to" some things in some men.

Thus, our New Testament documents range themselies in two main divisions. First, those which sprang from the culture-circle of Palestine, and are characterized by a predominance of the objectize or narrative element, though by no means to the exclusion of other tendencies. Second, those which originated in face of Gentile circumstances and needs, and are characterized by a predominance of an idealizing (sometimes theologico-philosophical) movement, though by no means to the exclusion of 
historical references. Necessarily, a common tradition, sadly overlaid and obscured in the canon, underlies both. The first group finds its great exemplars in the First and Second Gospels, and in Revelation. Of lesser moment are the Epistles of James and Jude. The chief witnesses of the second group are the Epistles of Paul, Hebrews, and the Fourth Gospel, with the Petrine epistles as subsidiary. The Third Gospel occupies a peculiar position. On its objective side it seems to belong with the Synoptics; on the other hand, some tincture from Pauline notions has flavoured it. But, as concerns Pauline admixture, the presence of similar influences in Mark serves to complicate the issue. I find it impossible to speak decisirely of the Acts of the Apostles. In my personal opinion - which, pray remember, carries no weight whatever - it may be regarded as standing between the two groups. That is to say, it furnishes a partial record of the manner in which the transition from the narrower to the wider environment was accomplished. Nevertheless, the standpoint of its author indicates sympathy more with the imperial than with the Palestinian outlook.

Thus, whatever document we traverse, we find the New Testament writings were motivated like 
other books, that they display throughout those eridences of the universal conditions incident to literary composition which must be at disposal ere we can understand or interpret written works. It must be perfectly obvious that an author who spoke Greek, and trafficked with Greek-speaking neighbours, who dwelt where the temple-cult of Jerusalem exercised no direct authority, and so forth, could not frame his views without betraying his situation. Only after frank reception of this and related facts, is it at all possible, at our late day, to pierce the New Testament literature so as to arrive at the tradition embedded there. The Gospels, the Epistles, and the rest -

$$
\text { " are pilgrim-shrines, }
$$

Shrines to no code or creed confined, The Delphian vales, the Palestines, The Meccas of the mind."

And, in the course of the journey, a great deal, taken for history once, falls away. Indeed, the first consequences of critical enquiry cannot but be negative. Let us look at this aspect of the matter for a moment.

Take, for example, the central figure, and, having submitted the New Testament evidence to critical examination, ask, What do we know about Jesus historically? If we set aside plausible tales that fit 
easily to preconceived and explicable notions, the result is nothing short of revolutionary to the average man. The Gospels contain 2899 verses; of these only about one hundred furnish strict biographical details. Aside from the record of the last days at Jerusalem, and of the teaching, our information about Jesus and his doings is scanty in the extreme. The objective facts startle by their omissions. Not only are the outlines of the faintest, but definite pronouncements are few and far between. Moreover, all the accounts are at second hand, and present amazing lacunce. Thus, the extent of our ignorance becomes the impressive conclusion of criticism. For the sake of this impression, let us review what we do not know. We do not know what Jesus' descent was. We do not know the year of his birth. We do not know his birthplace for certain. Our information about his family is of the most incidental nature. His early life, his manner of education, the whole formative period of his youth, remain unrecorded. Indeed, save for the single incident in the temple, they are matters of "reverie." 1 We know nothing intimately about the influences which led to the development of his religious genius, for his exact relation to

${ }^{1}$ Cf. The Education of Christ: Hillside Reveries, W. M. Ramsay. 
John the Baptist cannot be recovered. We are unaware how long his ministry lasted. We do not know his age at the time he undertook his mission. "If we start from quite critical premises, we must come to the conclusion that we have no absolute certainty that any single saying in the Gospels was uttered in that precise form by Jesus himself." 1 Our arailable information is such that we do not know what the Last Supper meant to Jesus. "Only one thing is probably certain, that at the original Supper Jesus did not mean to institute a sacrament in the Catholic, Lutheran, or Calvinistic sense." 2 In the same way, we are unaware what Jesus thought about his own death. "One thing only is certain, that Jesus never conceived or expressed the thought that God's forgiveness of sins depended absolutely upon his own sacrificial death or upon the vicarious atonement rendered by his death." 3 In like manner, too, we do not know what view Jesus took about the resurrection of the dead. "We have really no authentic information as to what took place at the trial of Jesus. Matthew and Luke assumed that he must have been asked whether he was the Messiah, and that he must have preserved his Messianic

1 Rud. Steck, in d. Protestantische Monatshefte, March, 1903.

${ }^{2}$ Jesus, W. Bousset, p. 206.

${ }^{3}$ Ibid, pp. 207-208. 
incognito to the end, refusing to answer the high priest's question. Mark, on the contrary, assumed that he admitted his Messiahship when the Messiah was defined as "the Son of the Blessed." It is evident that when these accounts were written, the terms "Son of Man," "Christ," "Son of God," and "Son of the Blessed" were all synonymous, or tending to become so, and that "Son of God" was equivalent to "God," so that the blasphemy of making oneself equal to God could be regarded as the charge brought against Jesus. Nothing could more clearly indicate the late and unreliable nature of this narrative." 1 We do not know where Gethsemane was. We do not know the year in which Jesus was crucified, and discrepancy exists even with regard to the month. We do not know where he was crucified, or where buried. We do not know what happened to his body after burial. The accounts of his post mortem appearances to his truant disciples present irreconcilable allegations. Still more startling, the evangelists are so sketchy, obscure, or conflicting that we do not know exactly what claims he made with respect to his mission on earth.

Besides, when we abandon the New Testament, and search the contemporary literature of the Roman

${ }^{1}$ The Prophet of Nasareth, Nathaniel Schmidt, pp. I49-I 50. 
Empire, the silence of non-Christian writers is most remarkable and significant. The first overt reference to Christianity postdates the probable time of the Crucifixion by more than eighty years. Still more disconcerting is the reticence, nay the perplexing lack of interest, characteristic of Paul. As a consequence, conservative and radical critics are in agreement perforce on one point at least. The facts necessary for a life of Jesus, in the objective or historical sense, simply do not exist. We are dependent mainly upon conjecture and inference that involve us in constant uncertainty. No doubt, Socrates and Shakespeare present parallel cases. But, even for the former, no such claims have been advanced as for Jesus; it was not alleged of Socrates, as of his pupil Plato, that he had a god to father. Nor does the astonishing recital close here. The same inference holds true, substantially, of all the men who are reputed to have composed the New Testament. Our information about the greatest of them, Paul, is most tantalizing in its fragmentariness. How a man such as he is reported to have been came to compose the Epistle to the Romans before 60 A.D. amounts to a first-rate literary mystery. In the same way, we know nothing about the writers of the First and Second Gospels; nothing, 
except, perhaps, his nationality and profession, of the charming litterateur who gave us the Third; and nothing at all of the profound genius responsible for the Fourth. Similarly, too, the eminent theologian who produced the Epistle to the Hebrews remains anonymous, like the strange seer-antiquarian who compiled the Revelation. Of the authenticity of the less important documents we know little or nothing.

Nevertheless, such happen to be disconcerting facts, too little appreciated, often not even apprehended, by the usual church-going Christian. IVe must needs face the resultant situation as best we can. For one thing alone stands out perfectly clear. Thanks to the paucity of biographical material, later generations drew thcir own pictures of an ideal Christ, and threw them back, in default of historical information. 'They filled out the vacant past according to their hearts' desires, and this without much reference to a possible historical basis. The oldest New Testament documents are, even thus early, illustrations of the process. Little wonder, then, that Christians are to be found who deny that their religion took its rise from a historical individual, and who insist that it "should be regarded as a particular development of social life, and not as the 
work of a personal founder of a religion " ; ${ }^{1}$ who declare:-

"There are narratives in the Bible which are even more vivid than the Christ-stories in their impression of personal reality, yet scientific research has definitely ascertained that there is no historical personality at the base of them. 'To take two instances that will be familiar to the general reader, the figures in the book of Ruth are very sharply defined and vivid, and the prophet Jonah has a perfect stamp of individuality. Yet there never was an historical Ruth or an historical Jonah as described in the story. Both narratives are entircly the outcome of religious poetry. 'They belong to a later Judaic age, and are intended to meet the increasing chauvinism of the Jews with the ideas of humanity and internationalism." 2

In short, thanks to the very barrenness of history, it has been deemed possible to trace the origin of Christianity, not to a man, but "to advanced Jewish thought, or to the philosophy, humanism, or socialism of Roman imperial times." 3 Briefly, the conditions in the Roman world were such that Christianity was bound to have arisen, Jesus or no Jesus. Extreme though it be, _ " a form of pseudo-

${ }^{1}$ The Rise of Christianity, Albert Kalthoff, p. 3 .
${ }^{2}$ Ibid., pp. I4-I 5 .
${ }^{3}$ Jesus, Arno Neumann, p. I. 
criticism," 1 - this position serves to show the straits to which the historico-critical movement may reduce us.

The complex problems, inseparable from the canonical sources as we have them, may be illustrated in yet another way; I mean by reference to the discrepancies that so abound. Time forbids more than the bare mention of a few of the more simple cases, and these I set down at random. They may serve, at least, as examples of many others, even more perplexing. Take, for example, the passages in Matthew xi. 2 f., and Luke vii. i8 f. How are we to interpret the series of miracles related here? Is the language a statement of objective fact, or is it a kind of symbolism? The answer would seem to be, We do not know. For, symbolic language is often upon Jesus' lips. "Can the blind lead the blind? Shall they not both fall into the ditch? . . . And why beholdest thou the mote that is in thy brother's eye, but perceivest not the beam that is in thine own eye?" 2 "It was meet that we should make merry, and be glad: for this thy brother was dead, and is alive again: and was lost, and is found." 3

${ }^{1}$ An Introduction to the New Testament, Adolf Jülicher, p. 28.
${ }^{2}$ Luke vi. 39, 4r.
${ }^{3}$ Ibid., xv. 32 . 


\section{And the famous statement of Mark-}

"And Jesus said unto them, Can the children of the bridechamber fast, while the Bridegroom is with them? As long as they have the Bridegroom with them, they cannot fast. But the days will come, when the Bridegroom shall be taken away from them, and then shall they fast in those days" 1 -

would appear to indicate that, on such occasions, Jesus has reference to the general situation of renewal resultant upon his work. And, if we force an objective interpretation, how can we reconcile it with the disclaimers entered in Matthew iv. $5^{-7}$; xii. $3^{8-42}$, in Luke iv. 9-13; xi. 29-32? These passages illustrate one type of discrepancy.

The following are of a different kind.

(a) Luke's account of the birth at Bethlehem contains several historical impossibilities and, moreover, traverses the tradition, implied in the name "Jesus of Nazareth," that Jesus was born at Nazareth.

(b) The discourses reported in the Fourth Gospel differ so completely from the sayings preserved by the Synoptists that one must conclude they were composed by the writer and then placed in Jesus' mouth by him.

$$
{ }^{1} \text { ii. I } 9 \text { f. }
$$


(c) A clear development of the baptism story is traceable from Mark, through Matthew and Luke, to John. The differences cannot be reconciled save by recognition of progressive elaboration.

(d) Mark and Luke recount that Jesus held one view about dirorce, Matthew's recital is at variance.

(e) Mark and Matthew tell one thing about the route taken on the last journey to Jerusalem, Luke another.

(f) The Synoptists recite words uttered by Jesus during the agony in the Garden, and yet, almost in the same breath, we are told that the disciples were "a stone's cast from him," and overcome with sleep. Who heard him, then? If the account be credible, plainly we know nothing about these words.

(g) Luke tells us that the Last Supper was eaten on the I 4 th Nisan, John says the date was the I3th. It is well to warn ourselves that this discrepancy has nothing to do with historical fact; it can be traced, however, to doctrinal prepossession.

(h) The Synoptists disagree in their reports of Jesus' words on the cross; and John records a conversation of Jesus with Mary, and "the disciple whom he loved," - who were not present at the time!

(i) The accounts of the resurrection contradict each other, and Paul's recital is not in accord with 
that of any one of the erangclists. There was no eye-witness of the erent, all the disciples had fled into Galilee. On the evidence as we have it, two questions can be asked legitimately. Did Jesus rise from the dead in a literal physical way? Or, did the disciples, their atmosphere being what it was, come to believe incritably that he had so risen? Which is the fact?

(j) How can we rcconcile the account of the postmortem appearance to the disciples at Emmaus (Luke xxiv. I3 f.) with the information, given presumably by the same writer, in Acts i. I f.?

(k) How can we fit the discrepant tales about the death of Judas, furnished respectively in Mattherv xxvii. 3 f. and Acts i. I5 f.? ${ }^{1}$

(l) Similarly, it is impossible, on any historical basis, to collate the story of Paul's life after his conversion, as given in Acts, with his own account (presumably), as giren in Galatians.

Thus it scems to follow, from a historico-critical investigation of the documents, that they are not to be taken as histories in any strict modern sense; and that to read them in this fashion is to commit grave error, fraught with dangerous consequences.

1 The probability is that both can be traced to the legend of Nadin, nephew of Ahikar, grand vizier of Sennacherib. 
In a word, the historical element is mixed with other factors that tend to transform it, and this in ascertainable ways. We may attempt to understand the matter by reference to the influence exercised by the Old Testament upon the men of the New, especially upon Jesus himself.

We are well aware that Jewish culture was not submerged in the huge sea of Roman-Hellenistic civilization, although it suffered dilution. In this connexion it is important to note that, so far as we know, all the New Testament authors were Jews, except the writer of the Third Gospel and the Acts of the Apostles. Hence a paramount consideration, forgotten too frequently even by professed students of theology. The New Testament cannot be understood apart from apprehension of Semitic modes of thought, especially as crystallized in the sacred literature of the Hebrews. Here I can do no more than indicate the subtle, all-pervading tendency imparted by the Old Testament.

The intricate problems of interaction between subjective ideas and objective events, inseparable from the sources as they have come down to us, require that we remember the part played by the Jewish Scriptures, - they provided the norms formative of life and applied to the valuation of conduct. 
They offered a set view, not merely of the duties pertinent to the individual man, but also of the destiny reserved for the people. In particular, they furnished an explanation of God's nature, and earthly government. Briclly, crery Jew, Jesus like the rest, was born into a well-marked spiritual penumbra. Such Psalms as the $\mathrm{ii}, \mathrm{xviii}, \mathrm{xx}, \mathrm{xxi}, \mathrm{xl}, \mathrm{lxiii}, \mathrm{cx}$, cxii, to name only a few, were susceptible of Messianic interpretation; and the same held of numerous passages in the other writings. A rast system had grown up round the Scriptures that intertwined everywhere with common affairs. Nothing could escape it, from the most ordinary trivialities of the daily round to the sublimest aspirations fathered by man. Besides, all this had wrought itself into the very marrow of Jewish culture, not by reference to a racial philosophy of history alone, but rather because the sacred books themselves formed the chief staple of national education. As Josephus says, "Moses had commanded that the children should be brought up in the knowledge of these Scriptures that relate to the laws." That is, the Old Testament supplied more than a theory of existence, it had become the instrument of ethical and religious discipline. To hear, to read, to recite, to transcribe the Scriptures, - this was the royal road to learning, as in Mohammedan Cairo, say, at the present moment. 
Apart altogether from any question of its influence over the nascent Christian faith, we can trace the Old Testament everywhere in the New, just because the Jewish youth were nurtured on it. Accordingly, we shall not be surprised to find its atmosphere present always to Jesus. When the Pharisees reproved his disciples, because they plucked wheat on the Sabbath day, Jesus took appeal to Scripture history. That memory played him false about the high priest's name (Mark ii. 26), that he was unaware these regulations postdated David's time, makes no difference. He enforced his opinion by the norms familiar to his people; in Matthew's version, he cited Hosea vi. 6, and no further justification of his followers was necessary. In the same way, when Matthew made Jesus enter Jerusalem sitting on an ass and her colt, he was simply following too faithfully Zechariah's statement: "Behold thy king cometh unto thee. . . riding upon an ass, even upon a colt the foal of an ass" (ix. 9). The Synoptist stuck to the letter of a language which plainly had faded from use. But the prophecy must be fulfilled. When a misunderstood linguistic usage is turned thus into what purports to be an historical event, we are in a position to judge of the immense leverage exerted by the Old Testament. 
Thus, for Jesus, the recitals and doctrines of the Scriptures constituted standards of judgement and appeal. His heedless contemporaries stand in like case with the sinners of Noah's day (MIt. xxiv. 37 f., Luke xvii. 26 f.) ; historicity counted for nothing. When he was confronted by the disciples of John, who asked, "Art thou he that cometh, or look we for another?" he replied with quotations from Isaiah (xxxv. 5 f.; lxi. I). In the Beatitudes he quoted from Psalm xxxvii. When he cleansed the temple (Mark xi. I7), he employed a phrase derived from Jeremiah (vii. II). When he discussed "washings of cups, and pots, and brazen vessels" with the Pharisees (Mark vii. 4 f.), he cited Isaiah (xxix. I3). Isaiah v. I f. is entwined with the parable of the man who planted a vineyard (Mark xii. I f.). When Jesus took a meal with the publican (Mt. ix. I3), he appealed again to Hosea. He denied the Davidic descent of Messiah by reference to Psalm cx, without any qualms of conscience about David's possible authorship. So, too, he proved the resurrection of the dead (Mark xii. 26) by pleading in evidence Exodus iii. 2, 6! When he made his entry into Jerusalem, after the manner predicted of Messiah, he found justification in Isaiah (lxii. II). When he commented upon the execution of John Baptist (Mark 
ix. I3), he recalled I Kings (xix. 2, Io), or, more probably, a lost apocryphon represented by the Slavonic Antiquities of Pseudo-Philo. When he silenced the Tempter (Mt. iv. Io), he was reminiscent of Deuteronomy (vi. 13); while the Tempter, when he urged Jesus to cast himself down from the pinnacle of the temple (Luke iv. Io), quoted from Psalm xci. I I f. Similar instances might be multiplied easily. Suffice it to indicate that, when he passed through the crises in his career, Jesus reverted constantly to the Hebrew Scriptures; even at the last dreadful moment on the cross, as Mark reports, he repeated the first verse of Psalm xxii.

So it is no way astonishing to find that the Old Testament worms itself into the very tissue of the New, - into Matthew and John, into the speeches of Peter, and Philip, and Stephen in Acts, into the sublime constructions of the Pauline Epistles; and that the Revelation summarizes age-old, possibly esoteric, expectations of Semitism as they took peculiar form in the Palestinian consciousness. Now, the Old Testament could be thus absorbed into the New, given certain conditions. If the New Testament were not primarily a history, if mere quotation from the ancient Scriptures could constitute irrefragable proof, could be put in place of real events, 
could clinch doctrine by simple citation, then the process, as we know it, could have taken place; not otherwise. It becomes plain, accordingly, that this very relation of the later to the earlier documents forbids us to estimate the New Testament as a work intended for a plain, unadorned, historic recital. I need hardly remind you that the average "Bible student," so called, has little or no knowledge of this elementary - and elemental - fact.

\section{Christian Syncretism}

Finally, the historico-critical movement has shown that, just as the early Christian consciousness sustained itself upon the Old Testament, so, within a generation after the Crucifixion, it began to adopt and adapt ideas current in the Hellenistic world. Like Buddhism, Christianity is a highly syncretist religion.

Primitive devotion to Jesus originated in an environment where Jewish (scriptural) notions reigned supreme. But, even here, other factors found place. The long association with Greek civilization, dating from the time of Alexander the Great (33 I B.c.), must be taken into account. The presence of Oriental influences, particularly in eschatological doctrine, is highly probable, while infiltration from the religions of Babylonia, and possibly of the Farther East, 
amounts to a certainty. Yet, even so, the Jewish clement preserved itself decisive. But, when the new religion migrated into Roman-Hellenistic circles, it was confronted by two systems, whose complcte domination and importance can hardly be exaggerated. One of these controlled the world of theor;, the other that of practice. The Roman Empire developed its spiritual life within the atmosphere of a perplexing conglomeration of ideas, doctrines, and aspirations compounded from Plato and later Greek thought, from the theosophical tendencies induced by Oriental moods, and from the peculiar drift of the spirit of the age. So, too, on the practical side, a great concourse of secret cult-societies honeycombed Mediterranean Europe. Derotees of the ancient Chthonic Mysteries abounded, because initiation was now a privilege open to all Roman citizens. The occult rites of Egyptian and Phrygian deities flourished luxuriantly, as we know from the satirists. "The Orontes had flowed into the Tiber." To these must be added the worship of the Emperors, and the peculiar situation in the Jewish Diaspora. Contrasted as they were, and appealing primarily to different groups in the community, the system of ideas and the crowd of religious observances did not circle apart on separate orbits. For, similar aspira- 
tions, fruit of identical human problems, swayed both theory and practice. Nor can this learen be said to have differed irremediably from some leanings germinal, if no more at first, in Christian belicf. Morcover, reconciliation saturated the spiritual atmosphere. Briefly, idcal motives, remarkable in their family likeness, affected all men, just because, mored by immense and missionary zeal, Christians coukl not stand aside, and stay untouched. Consequently, labile Christianity, as it insinuated itself rapidly into the syncretist stream, absorbed material quite foreign to its native (Jewish scriptural) character: this was ineritable.

For example, the Jewish Messianic expectation came to be allegorized by the Logos doctrine, derived from Plato, the Stoics, and Philo. The theosophical necessity for a mediator between God and the world replaced the hope that a great man would appear, commissioned to lead the earth to righteousness, as the Scriptures had foretold. Thus, in effect, the syncretist conception of the incarnate Christ eclipsed the humane career of the historical Jesus. As one of the most learned among Anglican divines has remarked:

"The conception of Christ as the Wisdom and the Power of God secmed inconsistent with the meanness 
of a common human life; and that life resolved itself into a series of symbolic representations of superhuman movements, and the record of it was written in hieroglyphs." 1

Accordingly, a new God - not the Hebrew Yahwéh, and a new Son of God - not the Jewish Messiah, achieved predominance in the Christian consciousness, and the doctrinal developments that were to differentiate Christianity so sharply from its Semitic forerunner displayed themselves quickly. The theory of Virgin-birth was adopted. The notion of divine paternity, so familiar to the Roman-Hellenistic world, so repugnant to the Jew, entered upon its fateful career. It guaranteed the efficacy of the mediation and salvation that lay close to the heart of multitudes of Roman citizens, drawn from every name under heaven. The Christian community possessed itself of a mystic notion that enabled it to respond to a popular demand and, at the same time, raised this to the purer altitude of its own vitalizing hope. In other words, a highly speculative doctrine replaced unmalleable historical events. The resurrection "on the third day" of the Phrygian Attis-cult, and of the Egyptian Osiris-cult, proof of the vicarious, victorious suffering of these

${ }^{1}$ The Hibbert Lectures, 1888, Edwin Hatch, D.D., p. 75. 
gods; the part played by the underworld in the Chthonic Mysteries; the obscure legends of Semitic apocalypse, connected with the Hebrew Abaddon and Antichrist, passed over to the Christians, and attained new consecration at their hands. The regnant theory of the Roman-Hellenistic world operated to these marvellous ends.

In like manner, the practical situation wrought strange consequences. The religious guilds,-Thiasoi, Eranoi, or Orgeones, - palpitating with fiducial enthusiasm, filled with zeal for moral reformation after their kind, read a lesson to Christians that they could not ignore. The Christian societies tended to assimilate themselves to these fraternities, just as, in any community, at any time and in any place, a new association will follow naturally the lines drawn by organizations already in possession of the field. So it is nowise wonderful to find that, little as Sabazius or Mithra, Serapis or Isis had in common with the ethical, non-thaumaturgic Judaism of Jesus, romanic Christians could not but be drawn by the success of competing and older clubs. Further, this tendency proved the more unavoidable that the worshippers of Mithra and the rest expected to obtain mortal purification and immortal life by reason of their devotion. Moreover, the god of the Thiasos had secured these 
benefits for his worshippers by personal suffering and death. The chastisement of their peace was upon him; with his stripes they were healed. So close was the spiritual parallelism that, as scholars have observed, had the religion of Mithra conquered the Roman world, as seemed possible at one crisis, Christianity would have descended to us very much in the guise which the Mithraic cult now presents to these investigators! Most naturally, then, the great Mithraic festival of Sol Invictus (spiritualized as the Sun of Righteousness) became Christmas Day; ${ }^{1}$ the period between the death and resurrection of Jesus, assigned by the Gospels, was that of the Osiriscult, just as the period, of different length, between Good Friday and Easter Day, agreed with the triduum of the Attis-Cybele festival. As the Christian community came to be composed more and more of Roman citizens, perfectly familiar with the organization, methods, and aims of the mystery-cults, so customs passed insensibly from the elder to the younger societies. "The four forms of Christian belief which we have been considering are the Virgin-birth of Jesus Christ, His Descent into the nether world, His

${ }^{1}$ It is a well-known fact that Eastern Christians (e.g. at Edessa) objected to the "idolatry" involved in the adoption of Christmas Day by the Roman community. 
Resurrection, and His Ascension. On the ground of facts supplied by archicology, it is plausible to hold that all these arose out of a pre-Christian sketch of the life, death, and cxaltation of the expected Messiah, itself ultimately derived from a widcly current mythic tradition respecting a solar (leity." 1

In the same way, the belief, current universally among the thiasic initiates, that the Redeemer-God must die, not only exercised profound influence over the direction taken by Christian belief and speculation, but also induced modifications of practice, as in Baptism and the Last Supper. We find, for instance, that, until this widespread idea had time to operate, - till about the close of the second century, - the abstract theory of the deity of Jesus received no fixed interpretation; in like manner, the doctrine of the Holy Spirit fluctuated freely for six or seven generations. So, too, the powerful conception of unity with other men in communion with a common deity, highly characteristic of the Roman-Hellenistic cults, made itself felt in the evolution of Christian practice. Baptism assumed the nature of an operative process; it became "enlightenment," "a seal," exactly as in the mysteries; it filled the office of an "initiation"

${ }^{1}$ Bible Problemis, T. K. Cheyne, D.D., Professor of Interpretation of Holy Scripture at Oxford, p. I 28. 
ceremony; while the baptismal formula assimilated itself to a "password," admitting the bearer to special privileges. The exorcism and anointment with oil, that came to be accompaniments of the rite, are traceable to the same source. False gods were abjured, and sins washed away, as in the thiasic ritual; in short, a thaumaturgic efficacy was imported thence. Likewise, in the Supper, the elements themselves became "mysteries"; the conception of sacrifice attained predominance; the sacramental reference occupied a chief place; and the necessity for a priestly intermediary formulated itself. The gulf fixed between the simplicity of the Gospel meal and the syncretized Christian eucharist, resultant upon Roman-Hellenistic infiltration, may be inferred from the following mystic narrative of Dionysius Areopagites.

"All the other initiations are incomplete without this. The consummation and crown of all the rest is the participation of him who is initiated in the thearchic mysteries. For though it be the common characteristic of all the hierarchic acts to make the initiated partakers of the divine light, yet this alone imparted to me the vision through whose mystic light, as it were, I am guided to the contemplation of the other sacred things.... The sacred hierarch initiates the sacred prayer and announces to all the holy peace: and after all have saluted each other, 
the mystic recital of the sacred lists is completed. The hierarch and the priests wash their hands in water; he stands in the midst of the divine altar, and around him stand the priests and the chosen ministers. The hierarch sings the praises of the divine working and consecrates the most divine mysterics, and by means of the symbols which are sacredly set forth, he brings into open vision the things of which he sings the praises. And when he has shown the gifts of the divine working, he himself comes into a sacred communion with them, and then invites the rest. And having both partaken and given to the others a share in the thearchic communion, he ends with a sacred thanksgiving; and while the people bend over what are divine symbols only, he himself, always by the thearchic spirit, is led in a priestly manner, in purity of his godlike frame of mind, through blessed and spiritual contemplation, to the holy realities of the mysteries." 1

Thus, as Hatch points out, "the whole conception of Christian worship was changed. But it was changed by the influence upon Christian worship of the mysteries and the concurrent cults." 2 One need only compare, say, even Luke's description of the Last Supper with the theurgic presentation given above, to realize how true this is.

${ }^{1}$ Quoted from Hatch's Hibbert Lectures, pp. 303, 304.

2 Ibid., p. 309. 
Finally, the full consequences of this syncretist process crystallized in the creeds. The transformation of the early faith was so profound that, even in the simplest of our "symbols" (a word, by the way, taken from the mysteries), the so-called Apostles' Creed, there is nothing, in all likelihood, which Jesus would have understood after the credal sense, except, probably, "the life everlasting" and, possibly, a certain aspect of the resurrection article. And the creed, recollect, is but "the baptismal formula enlarged" 1 - the password, as it were, to the "greater mystery," whereof the Eleusinian initiate could exclaim: "I have fasted; I have drunk the kykeon; I have taken out of the kisté; and after having tasted I have deposited in the kalathos." 2 Thus the beggarly elements of a less spiritual faith were baptized into the Christian consciousness. "The base things of the world, and the things that are despised, did God choose, yea and the things that are not, that he might bring to nought the things that are." 3

${ }^{1}$ Cf. The Apostles' Creed, A. Harnack, in The Nineteenth Century, rol. xxxiv, pp. $5_{5} \mathrm{f}$.

${ }^{2}$ The Eleusinian Mysteries, François Lenormant, in The Contemporary Revieze, vol. xxxviii, p. I44. Kykeon $=$ the refreshing draught; a sacred cake was taken out of the kistê $=$ the box or chest, touched and tasted, then returned to the kalathos $=$ wicker basket.

${ }^{3}$ I Corinthians i. $2 \mathrm{~S}$. 
Such, then, appear to be some results and tendencies of the historico-critical movement regarding Ancient History, the Old and New Testaments, and the Origins of Christianity. Sketchy as my summary perforce is, it may suffice to indicate the direction taken by research; and to render this unmistakable, I have set the material in high light. Further, many of the most distinguished scholars are banded, in a worldwide fellowship, to attack details that still remain obscure. The end is not yet, one dare not forecast the ultimate inferences upon disputed points. Nevertheless, it needs no argument to show that the movement has arrived, and arrived to stay. The labour of a century has not proved vain, and only a Mrs. Partington would deal with it after her fashion. The fait accompli stands forth to such purpose that the hazards of belief assume a fresh guise, one quite unprecedented.

“... Mortalia facta peribunt,

Nedum sermonum stet honos et gratia vivax."

Applied in this thoroughgoing style to the august construction of Christian dogma and doctrinal legend, the historico-critical movement, with its strict inductive methods, appears to produce veritable "humiliation in the midst." Notwithstanding, even if many problems rest unsettled, we are bound to remember 
that, after all, this type of investigation has little more than started. As years go by, it cannot fail to reap larger results, agreed upon by those who have earned the right to speak with authority, and backed by evidences that are sure to move thoughtful, candid men. Lengthened observation and reflexion have led me to conclude that, in spite of its present fluid state, we are destined to reckon with it. In any case, it is quite certain that the old elevation of doctrine and intellectual assent above life and moral worth must go by the board. Festooned with sacred memories as the ancient props are, a worse thing than this glimpse of historical truth may well befall us, if we persist in blindness to their real nature. Assuredly, in these days of popular education, the laity will come to know the facts, and cease to rest satisfied with garbled accounts of them; it matters little whether the garbling be undertaken in the interests of confessional orthodoxy or of propagandist rationalism. Slowly but surely the new knowledge is permeating society, and, as surely, accordant measures are, or will become, a clamant want. The parting of the ways will arrive, later if not sooner. Men in whose lives religion plays a vital rôle have need of all the courage and love of truth at their disposal. For, to be explicit, organized Christianity has been called to trial upon two counts, 
both of paramount importance to the twentieth century. On the one hand, the church must make up its mind whether or no its mission possesses meaning in relation to the democratic movement, rumbling underground now, destined to speak out full-throated to-morrow. It must decide whether its preaching is to take cognizance primarily of a possible life beyond the grave, or is, first of all, to concentrate upon the sublime petition, "Thy kingdom come; Thy will be done, in earth, as it is in heaven." With this, these Lectures do not concern themselves. On the other hand, the church must make up its mind whether the permanent elements of religion are to remain fettered, perhaps stultified, by hypotheses relevant in the fourth century, or are capable of plangent statement in terms of our contemporary outlook upon the world and life. In some respects, the latter is the most difficult problem before our generation.

Like all difficult and immense things, its historical course has been most complex and tortuous. So much so that one cannot say, lo here or lo there it took rise. Likewise, its sæcular trend, unhasting, unresting, still sweeps towards maturity. It awaits the alembic of a seminal personality, as we await the epiphany of its Plato or Augustine, of its Newton or Hegel. In short, no one but a great genius, of an 
individualized type superfluous or impossible in a former age, can transform the mysterious perspectives of belief. For he alone is able to bring forth from the treasures of heart and brain things both new and old.

But, be all this as it will, thus far we have not confronted our third 'universe.' So, in the Lectures to come, I shall ask you to reflect with me upon certain aspects of the religious and ethical consciousness. Possibly some glimpses may be vouchsafed us, if not of an undiscovered country, at least of a dimension of experience that eludes the strait canons dear to history. Yet, even this essay is sore beset by manifold difficulties, and encompassed with wandering lights. Indeed, these happen to be incidents wrought into the central importance of the subject for our common humanity.

"All I could never be,

All, men ignored in me,

This, I was worth to God, Whose wheel the pitcher shaped." Yea, verily! But, how to elicit this? How to convey it in the poor show of words, so apt to mumble or slur the quintessential? These mobile, ethereal tremors, and all the solemn questions they evoke, disclose the basal, poignant afflictions that hover about our paradoxical lot. I beg earnestly that you 
will realize the slipperiness of the possible foothold and, realizing, bear with my constant stumbles.

Note. - The following works are readily available for readers of English who wish to pursue the subject farther. An Introduction to the New Testament, A. Jülicher (Smith, Elder and Co., London): The First Three Gospels, J. Estlin Carpenter (Sunday School Association, London); The Johannine litritings, Paul W. Schmiedel (Macmillan Co., New York); The Fourth Gospel, its Purpose and Theology, Ernest F. Scott (Scribner, New York); The Life of Jesus, Oscar Holtzmann (Macmillan Co., New York); The Sources of Our Knowledge of the Life of Jesus, Paul Wernle (Philip Green, London); Jesus, W. Bousset (G. P. Putnam's Sons, New York); Jesus, Arno Neumann (Macmillan Co., New York); Paul, W. Wrede (Philip Green, London); Exploratio Evangelica, A Brief Examination of the Basis and Origin of Christian Belief, Percy Gardner (G. P. Putnam's Sons, New York); The Beginnings of Christianity, Paul Wernle (G. P. Putnam's Sons, New York); The Influence of Greek Ideas and Usages upon the Christian Church, Edwin Hatch (Hibbert Lectures for IS88, Williams and Norgate, London); The New Testament Articles in the Encyclopadia Biblica (Macmillan Co., New York). Messrs. Williams and Norgate, London, or Messrs. G. P. Putnam's Sons, New York, will furnish upon application a list of the works constituting the Crown Theological Library, which are admirably suited for all laymen interested in the Christian religion and kindred topics. 


\section{LECTURE V}

\section{THE PREËSTABLISHED DISCORD}

As we approach our further enquiry, let me say at once that I do not intend to elaborate a critical argument. In other words, I shall make no formal attack upon the technical conclusions of the scientific consciousness. This were absurd and, for the philosophy, superfluous. So far as our generation is concerned, it can afford to rest content with Professor Ward's rigorous analysis of Naturalism. ${ }^{1}$ Moreover, in another place, I have committed myself to the opinion:-

"As regards the mechanical theory, in particular, Dr. Ward's treatment may be taken as final. . . . The mechanical theory, the theory of mechanical evolution, and the theory of psychological parallelism fail as accounts of the universe as a whole. They can be proved insufficient and abstract, or partisan and illogical. ... The account of the manner in which the mechanical theory turns itself inside out in

${ }^{1}$ Cf. Naturalism and Agnosticism, James Ward, especially vol. i. 
the inevitable course of its historical development is masterly to a degree, and the same may be allowed of the measure meted to the half-monisms associated with the 'new' psychology. In the criticism of the theory of mechanical evolution the work rises to a very high level of dialectical skill." 1

This view I continue to affirm.

Nor shall I assault the findings of the historicocritical method. On the face of it, an amateur must admit the competence of a factual scienee within its own range. On the contrary, my desire is rather to elaborate a point of view, one that may serve, possibly, to stress activities of the ethico-religious life which contemporary studies and methods have tended to obscure, and have, as I believe, minimized.

Since Thales and his successors in Greece, thought has travelled many a spiral round, with infinite pains. Generally, it has passed from a vague cosmological standpoint, through a molar-mechanical one, to a molecular universe so ramified and elusive in its parts that the necessity for traffic with first principles seems to have lost emphasis. We need to circle back upon concrete experience, armed, however, with the ampler views won so hardly on

${ }^{1}$ The American Journal of Theology, vol. iv, p. $\mathrm{r}_{3} 6$ (in a review of the above). 
many levels. Science was made by man, it is his instrument, never his master. And from this judgement no species of science, natural or human, can claim exemption.

Nevertheless, it were impossible to overlook the issues raised in the previous Lectures. The appositions between science and religion, between criticism and faith, furnish a large element to the preëstablished discord that has afficted man immemorially never more keenly than at this good hour. To gain anything like a steady view of the situation on the whole, we must refuse to be upset by the insistent clamour of discrepant voices. This or that aspect of a matter may well disguise, nay conceal, the matter itself. The vast extension of knowledge in detail admonishes seriously to calm reflexion upon the immanent unity. If the fuller apprehension of nature and human qualities, acquired these last hundred years, compel us to recognize that the internal mystery has shifted its centre, it intimates also, and no less decisively, that mystery abides much as before. One method of solution, one path of escape, may have been foreclosed. That is all. What method or path? Let me reply, provisionally, as follows (I say, provisionally, because I happen to know theologians who could state an excellent case 
for their own view, who are equipped fully to look after it). Remembering this, then, suppose we take it for granter that the theological constructions, common to organized Christianity, are not reconcilable with modern knowlerge; suppose we agree to treat them as of historical interest only. I suggest this line for two reasons. On the one hand, and theoretically, many scientific authorities, followed by more students, think thus - the theological attitude is prima facie suspect with them. Therefore, they conclude that the Christian religion must go by the board. Whether this view, adrocated openly by some few, subconscious with a great company, can be maintained, we need not stop to ask. On the other hand, and practically, this course is open to me, because I am a layman, as it was not open to the clergymen who preceded me, as it may not be open to those who follow. Accordingly, let us drop the creeds frankly, on the alleged ground that they conflict irremediably with the conclusions of the scientific consciousness and of the historico-critical method. If we proceed thus, the question arises, Have we thereby dismissed "Christian truth"? The point of view I shall attempt to develop must confront this problem. In other words, we abandon the apologetic "defence of Christian truth," as formu- 
lated traditionally, in favour of an effort after "the establishment of Christian truth" by appeal to the constitution and active carecr of human self-consciousness. Our last 'universe' falls to be explored. In the Introductory Lecture we had occasion to see that "man's distinctive mark" proceeds from his double nature. The paradox happens to be that need and opportunity, failure and fulfilment, root in identical conditions. Calm the storm and stress thus originated, and religion would lose all meaning. Somewhere within its recesses, the character of every mature person responds to the heart-breaking sigh stereotyped in the words "the good that I would I do not: but the evil which I would not, that I do." Sooner or later, a human being is forced to comment thus, and, as a rule, upon events of the last importance to him.

"Life, like a dome of many-coloured glass,

Stains the white radiance of eternity."

Why? Simply because the career, wherein our lot expresses itself, appears unable to happen otherwise. Nay, the more significant it becomes in individual cases, the more it tends to illustrate this condemnation. We are driven, therefore, to expose the terms of the contrast in some detail.

No one needs to be told that, at present, it is cus- 
tomary to represent the conflict in but one of several possible ways, and this rather to the exclusion of others. Not only from popular parlance, but also from the charmed language of 'the schools,' we are apt to discover the opposition outlined broadly thus. The universe is two ultimately. One recognizes-

"that he has two sources of information, - his senses and his inner consciousness. When reflecting upon the mental processes by which the materials supplied by the senses are worked into thought, the Mind is watching its own activities. By self-study a man acquires a knowledge of knowing, thoughts about thinking. He knows that he possesses consciousness. It is not that he is consciousnessmerely a concomitant of a certain kind of nerveactivity. He owns a consciousness which he can direct and control; from which it follows that there is a He to own it. But the two sources of information must never be confused. The lines of thought for which the external and the internal worlds supply materials are parallel and neither diverging nor converging lines. A man's consciousness gives him no more information with regard to his science than his senses give him with regard to his consciousness. The two worlds are absolutely and permanently distinct." 1

${ }^{1}$ Some Problems of the Day in Natural Science: An Introduction, Alex. Hill, pp. 26-27. 
The physical, or energy, the psychical, or consciousness, present themselves as disparate orders, neither reducible to the other. And, when the individual comes in question, what holds of the macrocosm reappears in the microcosm. The body, with its neuroses, stands orer against the 'soul,' with its psychoses. No causal relation between them exists to afford convenient union, and so a symbolic representation of their final unity laughs us ironically into compulsory contentment of uneasiness. Flatly, the irreducibles remain irreducible. Doubtless, evidence abounds for this conclusion, if you regard the phenomena in a certain way. But, eridence or no, the demonstration lacks power to reveal the situation in detail. For, in the first place, it is obviously an abstract reflexion upon life rather than an exhibition of processes in concrete; and, in the second place, it is a judgement on the whole, or in gross. Putting the matter otherwise, we may well ask, Does selfconsciousness in any of its aspects, except the intellectual possibly, show up thus? Is the artistic, or the ethical, or the social, or the psychological, or the religious interest amenable to this presentation, and to no other? I think we are bound to reply in the negative. At all events, convenient as it may be to convey synoptically what appears an ultimate 
opposition, we have earned no right to rest in such a proposition prior to some enquiry about constituent factors and about definite presuppositions. Nay, one might be justified in the further allegation that not all evidence tells in just this single direction. Is the savage oppressed by the break, or the child? Is the average man, in normal moments, burdence? invariably by a profound sense that 'the physical' and 'the psychical' lock in deadly strife? Is he even aware from hour to hour that they fall apart, to move on separate plancs? Briefly, is it not true that practice, in large, declines to confirm this theory in large? Without attempting to pursue the problem, we must admit at least that doubt exists. Accordingly, it were more to our point - the investigation of the ethico-religious consciousness - to dismiss this method of approach, approved currently though it be, and attempt another line, one less general, more calculated to follow the mazes of the plain day's work.

Fortunately, perhaps, we are relieved from search for a beginning, our course thus far having left ro choice. The previous enquiry has served to elicit grave, if not alarming, contradictions between the deliberate inferences of the scientific consciousness and the historico-critical method, on the one hand, 
and the naïve beliefs of numerous - average representative - Christians, on the other. Indeed, as we have noticed, this preëstablished discord contributes a main element to the unrest of contemporary culture. Strange as the idea may appear, the best way to attempt a resolution lies along the path of further contact with discord. For, as yet, its possible implications have been kept in the background. Thus, we may set out by asking, Does the conflict characteristic of human experience become deeper when you pursue it into such details as natural science and exact history supply than it proves daily in the broad simplicities of common sense and even of popular philosophy? Are not science and 'causal' history themselves under a greater condemnation -one of the same kind, but acuter, because more explicit? Granted all their results, have they it in their power to assuage the yearning that produces religion? And, if not, can these very results remain unaffected in our judgement, especially with regard to claims, made for them by many, as vehicles of 'explanation'? We shall try to catch a glimpse of the principle suggested by these questions ere we proceed, in our next Lecture, to grapple with the ethical consciousness itself.

When we review experience, we are struck forth- 
with by the rast complexity of quite obrious ramifications. Life has differentiated itself on all sides; it revels exuberantly in exfoliating interests, many of them prone to dominate at different points or amid various circumstances. The primitive union of religion with custom and law, with government and morals, with philosophy and science, such as patriarchal story attests, corresponds to no actual situation in modern society. As a consequence, one activity may play the title-rôle on occasion, nay, come to masquerade as if it were experience in toto. The absorbed scholar, the skilful physician, the busy merchant, the ubiquitous politician fall under strong temptation to rate everything as intellectual merely, or physical, or commercial, or amenable to compromise. In every case the same implication rules; men tend to treat the familiar as if it were normative, to suppose that the truth dwells within their sphere of influence. Thus, when we take appeal to experience we must realize, and, if need be, force ourselves to realize, that this centrifugal movement sets our worst puzzles. For example, nobody requires close intimacy with the votaries of the sciences to learn that they evince a habit of assigning prime importance to their respective pursuits. Much of the goodnatured chaff that sweetens academic life, not a little 
of the acidity that sometimes sours it, run back to this palpable fact. Briefly, thanks to the progressive subdivision of experience, consequent upon ampler recognition of its tortuousness, any truth may be elevated readily to the plane of the truth. Let us probe this curious derelopment a little more deeply.

Adrance in knowledge depends upon awareness of problems, of contradictions. Science, as a process of investigation, consists in an effort to erase these blots upon consistency; as a system, complete so far, it surreys conditions of consistency in a particular field. If we find that a series of related judgements agree among themselves and, in addition, do not traverse other judgements proven empirically, we are entitled to allege that we possess a fragment of truth. Ye', such is the shiftiness of events that we must divide in order to conquer. But division, it so happens, implies much more than one notes commonly. Of course, on the face of it, to divide means to select, to choose a part from the whole. One fails to see as readily that the choice leads also to manipulation of the part in a specific way. Method arrives upon the scene. For, why choose? The physicist, to cite a case, preserves discreet silence about the odours, colours, and tastes of his objects. His world, when organized in truth, turns out some- 
thing totally different from the world patent to the average man. The plain inferences of common sense occupy no place here. Nerertheless, your physicist not only can, but does, enjoy eau de Cologne, beau brocade, and chartreuse with the same zest as his guileless neighbour. His science knows nothing about such qualities; at the same time, the qualitie: remain in his experience exactly as in that of the bon viveur. It demands no insight to understand why they have been disregarded pure and simple. Now, no science could remain science on the basis of such cavalier procedure. So it becomes apparent immediately that they have been disregarded for apposite reasons. Physics confines itself deliberately to quantitative investigations of special events in experience. By this self-denying ordinance its exponents hope to formulate results that would be beyond reach were qualitative differences permitted to intervene. That is, to conquer, the enquirer divides and, by consequence, holds the division for absolute in some directions. And if, as all would admit at once, physics be a more 'exact' science than biology, the reason lurks here. Biological material, by its very constitution, defies us to omit qualitative reference without ceremony. New qualities do present themselves, which cannot be foresecn like "prop- 
erties of matter." Hence, plainly, the larger part played by mathematics in physical science and, on the contrary, the greater constructive importance of experiment in biology. Thus selection proves to be no bare choice, it spills over into angle of outlook and method of procedure, both adopted with conscious intent.

I hope I have made it clear that anything worthy the name science-be it astronomy, chemistry, psychology, or history - proceeds upon a specific agreement a quo. Experience must submit to disruption if truths be in demand. As matter of record, every science adopts this plan at the outset. But the rank and file even of educated men fail to notice that the plan conditions the conclusion also. For instance, I am quite able to follow the chemist when he says that an atom of copper or of oxygen is capable of conveying a quantity of electricity twice as great as that conveyed by an atom of hydrogen or of iodine. I take it for granted from him that the atomic theory offers an ultimate description of the events he has segregated in his selected universe. But, at the same time, I have no difficulty in agreeing with the moralist when he says that definite rights bring definite obligations, and that these obligations are capable of expression in the form of commandments. I take 
it for granted from him that the theory of a "kingdom of ends" - of beings who are never mere means, but possess a purposive carecr - offers an ultimate description of the events he segregates in his selected universe. Nevertheless, I notice instantly that the truth of the one proposition lacks application utterly in the region where the other reigns supreme. The two judgements circle quite apart; yet, both belong equally to common life, - the one holds no more truth than the other. Essentially, then, each is true only under partial conditions. Neither runs freely through the entire range of experience. Moral atoms and chemical persons cannot be even figments of the wildest imagination.' The divided universe abides divided. Now I am anxious to have you understand that a large proportion of contemporary difficulty about religious belief originates precisely from suppositions on all fours with the absurd idea that moral atoms and chemical persons not only exist, but are the sole real existences. Science and religion have been conversing in unknown tongues, with the familiar consequence - complete, and mutual, unintelligibility. How so? We may answer the question, first, by reference to the preëstablished discord of experience

${ }^{1}$ Although Huxley did forget himself once so far as to think not (cf. Works, vol. i, p. 275). 
as it issues in Naturalism. For here we find a typical case illustrating the illegitimate, if inevitable, transmutation of $a$ truth into the truth.

Men live through series of events numerous beyond calculation, and complex beyond immediate comprehension. So long as the welter and involution run riot, it is hopeless to extract explanations more satisfactory than brilliant - or foolish - guesses. A febrile patient betrays delirium - we suppose that an evil spirit possesses him; a man may not marry his aunt - we suppose that a divine command interdicts; an eclipse occurs - we suppose that a dragon has supped on the sun; a volcanic eruption overtakes a city midmost work and play - we suppose that some irate Titan, dwelling beyond the skies, has hinted disapproval of the stock exchange, or of faro and bridge. And so long as we permit events to overwhelm us wholesale, so long we must continue to invent myths. Accordingly, in its last analysis, science comprises no more - and no less - than a concentrated effort to understand a group of like facts, by isolating them from the bewildering mob, and thinking about them with rigid consistency. The human intent here is to gain mastery, to dispel ignorance, to discover means that may lessen our terrible impotence. Thus we see clearly why, in its very 
nature, science cannot but be abstract. Experience meets us in such doubtful guise that, unless we separate a part from the whole and treat it, for our immediate purposes, as if it were still the whole, we are bogged in intellectual and practical babyhood. Any science one cares to name affirms its particular subject-matter, and its particular aim, in opposition primarily to the necessary vagueness of the empirical sum-total. It claims the right to construct its own special purview, and stands ready to be judged by results. Candidly, it starts from and ends with a hypothesis. If the conditions governing the events selected for examination be so and so, then such and such consequences may, usually do, ensue. But these conditions find place in the chosen sphere only. A physics of faith, an ethics of granite, are imaginary and inapplicable.

Take a familiar illustration. The astronomer avers that the moon "must be revolving in a nearly circular path round the earth as centre." Undoubtedly, this seems a most innocent and incontestable proposition. It recommends itself quickly to all except the crank whose 'perception' proves the earth flat. Nevertheless, the slightest examination serves to convince that the statement can mean something only if certain eliminations be permitted. In other words, the ' universe' where the judgement holds 
true is the creation of what we may term the astronomical intellect. For, on a little reflexion, we find the sun productive of perturbations such that the alleged path of our satellite continues but a moment on the arc of any given circle and, immediately afterwards, follows that of another, and so on indefinitely. Now this sum of hypothetical positions might combine, conceivably, to produce a waving curve circular on the whole - "a series of curves with their concave sides downwards." Yet, even so, the earth happens to be speeding its impressive whirl about the sun; accordingly, admit this second disturbance, and the "circular on the whole" conveys no meaning whatever. Further, the sun acts like a giant locomotive, pulling the solar system "through the heavens" at fearsome pace, relative to the positions of other stars. Moreover, as astronomy itself has come to know well recently, these other stars are active participants in the sublime procession. Import all your conditions, and you are bound to confess that you are as ignorant of the moon's orbit about its primary as you are of all that lies -

"Beyond the path of the utmost star through utter darkness hurled."

Is the astronomer, then, a kind of amiable lunatic? By no means - any mariner will tell you that he is a 
most useful animal; for, has he not pointed out that this very motion of the moon furnishes a master-clock, to keep tab on the chronometers during a long voyage? Nor is the implied contradiction so extraordinary as it appears. To obtain unified knowledge, the astronomer has adopted a certain method of procedure, one so well understood as to be conventional - that is all. Perhaps, indeed, he presumed too much on the capacity of the layman in his positive statement. For, what he intended to say was this: if you have two masses such as the earth and the moon, constituting a system in which the primary and the satellite move at a mean distance of 240,000 miles; and if their motions be not perturbed by interference, then the path of the moon with the earth as centre will be nearly circular. Granted, some wiseacre will argue, but what right has the astronomer to eliminate thesc known perturbations? The reply is, This is the essential method of science. If, within any group of empirical events, you find it possible to cancel concomitant phenomena, because they do not create disturbance sufficient to compel an accounting, then, for practical purposes, you may treat them as non-existent. Otherwise, advance in knowledge would be impossible. And, mutatis mutandis, the younger sciences follow their venerable sister - to them she offers a type of 
'exact' work. Nay, if they could but translate their synopses into the terms of her vast simplicity, they would compass assurance uncloyed by hesitation.

It will not surprise us to learn, then, that no cautious scientific man transgresses his self-imposed limits. He refuses to affirm that his conclusions, or those of his science, suffice to explain the totality of experience. Sensible of irrevocable conditions, he will not commit himself to more than this: 'Permit me to concentrate attention upon a group of similar or identical events; permit me to discard all individual (maybe freakish) factors within this group inconsiderable enough to disturb unitary grasp; this agreed, I undertake to tell, nay, to foretell, what is very likely to happen within the circle of known or observed phenomena. Natural laws embody human judgements; cause is an indispensable tool in man's intellectual armoury; a hypothesis is a provisional arrangement and, as provisional, becomes a goad to further enquiry, to more thorough reflexion. In its own proper function, science knows nothing about law, or cause, or hypothesis as such, much less about "the moral order of the universe," or about God. Competent in variable degrees, dependent upon opportunity for investigation and possibility of formulation, the sciences lay no claim to dictate in other fields. 
They keep the peace among themselves. The sane physiologist would not go about to advance his work by bullying the psychologist, eren although their pursuits intersect. In other words, a cardinal principle of the scientific temper is non-interference, because what holds in one sphere may prove a hindrance in another, or, peradventure, a source of active error. You cannot universalize a 'positive' science. The procedure would evaporate all the characteristics that make it worth while.'

But, if I have contrived to render the position evident, what is to be said about the touted menagerie of quasi-scientific bogies that has toured the Western world these last eighty years? What of Materialism, Agnosticism, Naturalism, and so forth - the bloodless centaurs that still harry hapless humanity? I would venture the guess that, possibly, they are a troop of hallucinations bred by auto-suggestion upon selfconfidence. Recent thought has won its most superb conquests on the broad field of positive science. Intoxicated by success, its memory needs to be jogged on the subject of the conditions precedent to 'progress' in studies of this kind. For all these rampageous 'isms,' if tracked to their common lair, prove very innocuous beasts. One of them - Materialism met ruthless death recently; and the others, para- 
doxically, are more difficult and more easy to slay for one and the same reason. More difficult, because Materialism did possess what purported to be a body; more easy, because in them many frantic lovers have contrived to give-

\section{"to airy nothing \\ A local habitation and a name;"}

and love offers no atmosphere to criticism. Yet the delusions yield to rather elementary scepticism - in fact, after all the pother, this is their disappointing feature. We are met by another instance of popular metaphysicizing and, as usual, of self-deception. Experience was fated to humbug itself.

Any science, that is, any body of judgements about a part of experience, becomes self-contradictory, if you insist that it transform itself into a rational account of experience as a whole. Nay, it might be maintained that, precisely in proportion as a science conforms to the ideal of 'exactness,' it declines in truth when universalized, just because it is less able to grasp, or adjust, individual cases. The more we can eliminate from the group peculiar to a special science, the more 'exact' the possible results; but, conversely, the less is the science equipped to present in detail the larger whole whence it fissured at first. 
The personal escapes it; so let us be personal for a moment. It is interesting, no doubt, to learn that Mr. Taft weighs nigh three hundred pounds. Yet this numerical evaluation informs us no whit on his present meaning - it is silent upon the 'how' of his nomination to the Presidency of the United States. We are glad to know, as an additional fact, that Senator Fairbanks exceeds the average American in height. But, thanks to the incurable vulgarity of the press, his supposititious addiction to "buttermilk highballs" counted far more emphatically in his descent from the perilous levels of haute politique. That is to say, the weight and the height are true, with incomparable truth, in their proper places, for they may count as paragons of the 'exact.' They are thus true, however, at the cost of desperate poverty, when it comes to social issues in the concrete. The veriest yokel would bubble with mirth were one to suggest solemnly that they told "the whole truth." Unseemly and rude jest aside, Mr. Taft does not connote mere girth, Mr. Fairbanks mere length. Now, the putative fathers of Naturalism have committed themselves to just this Gilbertian fancy, and have contrived to affiliate upon respectable science a precious family of infant encumbrances. It were well to remember that, within her own household, 
no responsibility can be saddled on science. Naturalism is the latest gift of the ghostly stork, a tribute to the generative power of the preëstablished discord immanent in frail human experience.

Strangely enough, Naturalism results primarily, not from the analysis of physical facts, but from the pressure of ideal demands. In a measure, the very existence of science renders it inevitable; a suprascientific synthesis comes forth to crown minor syntheses. For, scientific enquiry finds its dominant motive in the desire to reach complete accuracy. Self-sustained and self-witnessing unification offers the sole end worth pursuit. But, just on this account, human experience becomes a house divided against itself. The aim thus projected under stress of circumstances may be attained so far, yet at a round price. Man must agree to walk the strait road of stringent rule. He must adopt a literal interpretation of the familiar maxim - this one thing $I$ do. Perforce, other things are jettisoned ruthlessly. Accuracy after its kind may ensue, but only at the expense of constant elimination. Thus the scientific labourer finds his ideal incarnate in a definite type of work, governed by equally definite method. To these he conforms, whether he recognize his course fully or not. A distinguished physiol- 
ogist of my acquaintance slipped the cat from the bag in conversation with me once. We were debating the difficulties incident to various classes of research, when he exclaimed surldenly, not without emotion, "If only my subject were like physics, how easy it would be to determine the facts." He implied, of course, that, if he could simplify his material by exclusion, many of his insoluble problems would disappear. He failed to see, however, that the remainder would not afford problems in physiology. Given the same conditions, were this practicable, there is no reason why the physiologist should miss the 'exact' as the physicist views it. And here we have a most significant intimation. Most naturally, the physico-chemical standard of 'exact' knowledge appeals to workers in other fields as the ideal norm regulating their conformity. Historically, celestial mechanics furnished the methods of measurement in space and computation in time that enabled science to start upon its conquering career. Hence, too, the negative side of the same notion. Many competent masters in the exact sciences cannot conceive how history or sociology - much less philosophy - have remote title to a place in the realm of 'positive' study. Nevertheless, they betray no consciousness of the apposition between an ideal that motivates all 
research, and the conditions that conspire at once to satisfy and to stultify it. So, despite logic, the partial satisfaction, lying within reach, comes to be grasped, while the precedent, and indispensable, restrictions to space and time, that produce stultification outside this limited range, lapse into oblivion. Amid the excitement of pursuit, men forget that the nature of its starting-point forces their chase into endlessness. The implied problem evaporates, because -

"Stultus ab obliquo qui quum descendere possit, Pugnat in adversas ire natator aquas."

If we are to be 'exact-scientific,' as our German friends say, what conditions frame the ideal? As we have seen, it is out of the question to reach any 'exact' conclusion except on a basis of deliberate simplification. For this reason, the conditions prove comparatively simple, all things considered. They are (I) stability or identity for human consciousness of the objects studied; (2) ready application of measurement and enumeration; (3) continuity of the segregated phenomena on the whole. Granted that all men can seize essential marks of the chosen objects in the same way; granted that series of observations can be averaged and stored in mathematical formulæ; granted that the adopted series be 
continuous - that it be divisible into portions by any one of its terms, yet without a 'real' break, and that, therefore, any term may be referred to another as its precise consequent; then you obtain a flow of inevitable sequences, and partial induction may be lifted to the level of confident prediction. In short, you possess a scheme which works admirably within its range. Moreover, you are bound to admit its competence so long as it keeps its own corner of the garden. So far, so good. But the question arises forthwith, What follows from the admission, or adoption, of these self-denying ordinances necessary to 'exact' results? The answer lies on the surface. Let us take the requirements successively.

(I) What kind of information about any objects do all men possess in common? Plainly they know such characters as are dependent upon the external senses or, otherwise, such as are capable of expression in unequivocal symbols. Conceptions differ enormously from individual to individual, but perceptions possess a relative identity, stable enough for practical purposes. I cannot, by any alchemy, transfer my concrete mental, moral, and emotional states to another; but I can illustrate some few of them by means of symbols that hold universally for the special senses. No unity of experience is practicable for 
a knowledge compressible into precise terms, except the very general judgements based upon the organism of percipients. What we call spiritual life, for example, is so acutely personal as to evade simple transfer from man to man. Accordingly, for the purposes of science, the unity of experience means no more than the average identity of impressions of sense. Hence, of course, the crude doctrine, that experience $i$ s these impressions, and naught besides. The real fact happens to be that we have restricted experience ourselves, by adopting a specific attitude towards it, for a concerted and entirely justifiable purpose. The preëstablished discord, that is, pivots upon an attempt to extrude the ideal element, in order to arrive at an ideal. Deny the ideal, in an effort to universalize the partial position, and illusion becomes the unavoidable consequence. The scientific transcription is true on its own recognizances, but misses application to the ideal process whereon this truth depends. Sense averages are predicable of sense averages; the effort to employ them elsewhere occasions the worst stultifications of misunderstanding.

(2) The call for the reduction to standards of number and measurement flows directly from what is known as the Law of Parsimony. Among its many 
invaluable scrvices, positive science has devised a magnificent scheme of syncopation. Given an 'exact' result, given the means of reproducing it unchanged, and you may adopt it fearlessly as the sure basis for further work. You inherit the harvest of the ages for your use. Now, we cannot store our imaginations, loves, sorrows, in this fashion. Hence their intense strain upon temperament. But we can minimize intellectual labour, by employing the triumphs of our predecessors, in relation to events capable of retention by terms of number and magnitude. Omit the specifically human, treat those of 'our' events in which we stand on a level with the rest of the cosmos and become accidents of it, as if they alone spoke our secret, and you can formulate per $x$ and $y$ with thoroughgoing success. Still, remember all the while that you can so proceed only with regard to "many-one relations of all times to some places, or of all terms of a continuous onedimensional series $t$ to some terms of a continuous three-dimensional series s." ${ }^{1}$ Here, once again, an ideal has dictated the means to its own realization; these means, as applied irrationally to all experience by Naturalism, expel the ideal reference. And so,

${ }^{1}$ The Principles of Mathematics, Bertrand Russell, vol. i, p. 473 . 
when one tries to universalize them, the illusion prevails that the ideally arranged conditions furnish irrefragable proof of the non-existence of the ideal.

(3) The demands just noticed concern the nature of experience itself. The third bears another reference. It asks that the object of knowledge assume a nature of its own - that it must be contimuous. In the present connexion, I cannot diverge to pursue the necessary analysis, for it leads straight to the difficult and, frankly, ill-understood, problem of causality. One would suppose that, at this late date, Hume had contrived to clear men's minds of cant about cause; unfortunately it is not so. Notwithstanding, it is clear that, unless a series of phenomena be continuous, the connexion of one event (as effect) with another (as cause) transcends possibility. Causes and effects, as such, are bound to rank as occurrences in a single, seamless process. Apart from this texture, 'exact' science would prove the merest dream. Now, the 'fact' owes its existence, not to a universal series, but to a special series systematized ideally in a certain way. A logical principle of synthetic unity betrays its presence in causality - or there are neither causes nor effects. Thus, to obtain our results of precision, we posit an ideal truth; and then, in our naïve Naturalism, proceed 
to deny the ideal on the basis of its own consequences. I know this is not philosophy, I should be "black ashamed" were I compelled to suppose it science.

On the whole, then, and from the nature of the case, Naturalism offers but another example of the preëstablished discord that overtakes men whenever they try to explain their ' universe' by reference even to their best knowledge of a small part thereof. Further, it happens to be no conclusion from any, or from all, science. Fundamentally, it is a metaphysical speculation invented to account for the presence of the ideal eliminations under which science originates and must proceed. Huxley's brilliant analogy of the garden which, though a "result of the cosmic process, working through and by human energy, the influences of the state of nature are constantly tending to destroy," 1 offers an admirable illustration of the inner contradiction that drives humanity to seek rest, not in a lesser whole universalized illegitimately, but in the broad sweep of a larger life. Yet the pure intellect fails to absorb the lesson ere it has ventured upon the universalizing process, oblivious of the initial restrictions that made its practical use successful. But when, overcome by the deep and inevitable contradictions that arise,

${ }^{1}$ Cf. Evolution and Ethics: Collected Works, vol. ix, pp. 9 f. . 
it proceeds, as it did at last in Huxley's person and swan-song, to try again in an ethical realm, it simply obeys the necessary logic born of its analytic devices, which accomplish results by open neglect of remainders. For Naturalism "begins with real bodies in empty space, and ends with ideal motions in an imperceptible plenum. It begins with the dynamics of ordinary masses, and ends with a medium that needs no dynamics or has dynamics of its own. But between beginning and end, there are stages innumerable; in other words, the end is an unattainable ideal." 1 A tale that is told, Naturalism may be dismissed with a tale. A Scot, given to the vices of his folk, informed his minister that he intended to travel in Bible lands. "When I climb tae the top of Mt. Sinai," he added, "I'm gaen for tae read the Ten Commandments." The wise and witty parson replied, "Man, Sandy, ye'd faur better bide at hame and keep them." If the representatives of the positive sciences would stick to their last, - and, remark, the best usually do, - advance would not be stayed, to say the least; and we should not have to encounter delays due to bewildering fogs of bad metaphysics. As Professor Mach has pointed out,

${ }^{1}$ Naturalism and Agnosticism, James Ward, vol. i, p. 153 (ist ed.). 
"the highest philosophy of the scientific investigator is precisely toleration for an incomplete conception of the world and the preference for it, rather than an apparently perfect but inadequate conception." 1 But, worse luck, man is not built this way. He must criticise his scientific categories; and he finds frequent vent for his need in the supposition that their transfer to a suprascientific field constitutes criticism. Nay, he spurns deliverance from this body of death. Naturalism, the executioner of the ideal life, remains a standing witness to this very life - only it stands on its head. Its easy psychology, beatified in epiphenomenalism, fails to transcribe the concrete facts of the psychical process, and displays laughable contentment with a conspectus of parts riven from the whole. Still, it were worse than useless to complain. For, once again, we are -

"Striking the electric chain wherewith we are darkly bound."

In conclusion, we pass to the decisions of the historico-critical method. At the close of a lecture, it is far from my intention to canvass one of the most difficult problems now before the human mind - the ultimate import of history, and the consequent re-

${ }^{1}$ The Science of Mechanics, p. 464 (2d Eng. ed.). 
lation of precise historical knowledge to the validity of religious belief. ${ }^{1}$ For the question necessitates a profound critical excursus into the legitimate meanings of the terms 'Time' and 'Eternity.' Besides, philosophy herself stands but on the threshold of this baffling subject. However, I must try to exhibit the movement of the preëstablished discord within the historical range. It infects the standpoint of history, when universalized, no less than the popular metaphysics of science. When the rude facts concerning Jesus, as adjusted with cool accuracy by historical method, are taken, and when the 'historical' allegations as formulated in the Apostles' Creed, say, are placed in juxtaposition, but one inference can follow. It is this. Christians of the traditional type seem to have been fated to make tarts from Dead Sea fruit. What was, as the actual record runs, is neither what they are required to believe, nor what many of them desire it to have been. Cook the ingredients as you will, the brew smacks of anticlimax. Mutat quadratarotundis, as Horace said. As an evident consequence, we encounter the preestablished discord in another of its ubiquitous

${ }^{1}$ I may be permitted to refer to my paper, Historic Fact and Christian Validity, read in part at the Detroit meeting of the American Church Congress, May 14, I908, and printed in full in the Proceedings. 
phases, one distressing beyond measure to all faithful souls. It were well worth while, accordingly, to pursue it, if only a short way.

What is the consensus of opinion about history among experts, whose competence guarantecs their right to testify? The reply admits of no doubt. History is, first and foremost, a series in time. As such, it presents two characteristics, so essential that, apart from them, it would become a vapid phantasmagoria. It is single, and irreversible. In other words, it must conform to the demand for continuity, just like the material of physical science, and its terms must interlock in some form of causal relation. Given these conditions, and history falls within the circle of practicable research; withdraw them, and the science goes to pieces. That is, history betrays determination after its kind and, within the sweep of the determination, the parts played by single events or individuals may be reduced to the level of accidents. They hold no sort of virtue in their own right, as it were, because their hammered concatenation in the sequence alone bestows significance. The "fatalism of facts," foreseen long ago by Quinet, rules now, a conditio sine quâ non. As we saw in the case of science, so in that of history, it were worse than useless to vent 
complaint. For the complainants inhabit outer darkness, as concerns ability to sit in judgement. We might just as well carp at the physicist, and refuse to have water led into our houses, because water does not rise to its own level, as dismiss the historian, learned in the 'causes' of the Boston Tea Party. In practice, we agree with both. Why? Because both can plead the same justification for the conditions necessary to their craft; without the antecedent standpoint, neither science nor history could exist to serve mankind. Remove continuity and cause, you shatter the very possibility of history. Vague generalities, a priori abstractions, idealistic formulæ, never give body to history; on the contrary, they cloud the factual issues. Take Augustine's delicate fancy: “Deus ... ita ordinem sæculorum tanquam pulcherrimum carmen etiam ex quibusdam quasi antithetis honestaret;" 1 it may rank as excellent poetic licenseabout real history it tells less than nothing. A series of causal filiations never moves even remotely like rhetorical 'contraposition,' as Quintilian called it. Along with all other objects amenable to a single systematic order, historical units happen under the strait limits of space and time. To write history is

${ }^{1}$ De Civ. Dei, xi, 18. 
to uncover the causal filaments, by inexhaustible diligence in amassing the incidental occurrences, by impartial judgement of evidence and, on this basis, to elicit 'explanation' of the facts from the correlations traceable within their own process. The death of this man, therefore, ranks on a level with the death of that. Find the relevant circumstances, follow the phenomenal interplay and, irreversible sequence given, events will be found to explain themselves on the same general lines. Nothing remains to be added. Anything else would transcend the canons of history, ipso facto, history would cease. Within this purview, on the face of it, no demise of an individual can acquire exceptional meaning for religion. And, as for positive science, so for history, we are bound to accept its own account of itself without reserve. Encased in crass ignorance of every method and canon of judgement used, the average man dare not do less. His practice shows his sense; he takes his history, as he takes his train - on its own terms.

Nevertheless, time out of mind, organized Christianity has insisted that a tiny morsel of history, minute in time, circumscribed in space, be wrenched from the vast series and exempted from normal conditions. Splendide audax, as only the oblivious 
can be, the official Christian bases his hope of salvation upon some few obscure happenings, of which we know almost nothing, in an obscure corner of the Mediterranean world, of which we know little. He alleges that they were historical occurrences, abnormal to infinity. And yet, as 'exact' history sees these things, less than no evidence exists to raise them from the rank and file marching in causal sequence. Moreover, the adherents of other ethnic religions have set, and followed, the same example. The historical attitude to Buddhism and Mahommedanism stands on all fours with its ultimatum to Christianity. Could the preëstablished discord go farther, or make us fare worse? I think not. For, consider the tremendous character of the apposition. Historically, Jesus was a man, born like other Jews, circumstanced as his neighbours; a disturber of civil peace - tried, condemned, and executed like other undesirables; then a corpse, entombed, and returned to dust like other corpses. Yet, for Christianity, despite the prosaic nonchalance of historical facts, "God so loved the world, that he gave his only begotten Son, that whosoever believeth in him should not perish, but have everlasting life"; and, "If Christ be not risen from the dead, then your faith is in vain." Again, I ask, 
could discord go farther ${ }^{1}$ Evidently, the events as possible within any causal time-series, and the affirmations of belief, move on two totally different planes. Notwithstanding, Christians have been forward to urge that their religion finds its sole sure basis within the time-serics where, historically, it cannot belong, by any admission open to contemporary knowledge. Further, the Christian allegation is not susceptible of proof by objective evidence, nay, the evidence now recoverable has been turned against it with terrible effect. The appeal to history, once taken so confidently, has declined to the dismal level of a cry ad misericordiam - 'for any sake, and in the name of anything you hold holy, allow the probability or, at least, the possibility, of our plea'! Verily, a situation profoundly pathetic!

It needs no keen perspicacity to see that here, as with the scientific consciousness, the preëstablished discord has eventuated in an impassable chasm. As the conditions precedent to 'exact' science baulk the satisfaction of desire to rationalize the universe, so the standpoint inseparable from causal history vetoes the longing of religion to detect a special

${ }^{1}$ It is hardly necessary to point out that this discord underlies the problem of Christology in its classical forms (cf. my article Christology, in Baldwin's Dictionary of Philosophy and Psychology). 
revelation in some events incident to the hazy past. But the cases are not parallel entirely. Driven by the innate human demand for an explanation of all things, the scientific consciousness attempts selfsatisfaction by spinning a theory out of enumerations in time and measurements in space - limitations inapplicable to any consciously presented kosmos whatsoever. As a result, men are condemned to labour in a quarry for fallacies. Driven by the human demand for a definite guarantee of the completion which religion seeks, the Christian attempts self-satisfaction by transfiguring a fragment torn from the temporal series of history, where religion, as contact with the eternal, cannot abide. As a result, men find themselves abandoned, defenceless, to the panoplied assault of rationalism. The same effort of human nature, to achieve an inclusive experience, results in the same discord, though by different processes.

Thus, the preliminary stage of our constructive enquiry appears to end in a stalemate. Yet we have gained something. In the first place, and negatively, we have found that a mechanical phenomenalism, confined to quantitative forms in space and time, cannot furnish means to formulate an explanation of experience on the whole. It omits the 
very things most in need of explanation, and without this omission could not proceed with its own work. Bcyond its chosen range it is helpless, because quite impracticable, when individual variations call for an accounting. In the second place, and still negatively, we have found that Christian phenomenalism, which would set the fundamental truths of religion in an irreversible time-series, is helpless to discover them there, without destruction of the entire posited scries. In the third place, and positively, we have found that both movements issue from an inalienable need of our nature, and that, forced by its clamour to these issues, men become entangled in insoluble contradictions. Nothing else could come of essays either to make the conceptions of 'exact' science include the cntire content of experience, or the sources of historical knowledge knowledge about $a$ religion - the principal and normative content of religion itself. Accordingly, we have travelled so far as to be able to rid ourselves of a self-stultifying Naturalism, which cannot proceed from an abstract universe, 'outside' consciousness supposedly, to the universal in consciousness. But we have not succeeded in ridding ourselves of self-contradictory religious supernaturalism, which cannot proceed from a timeless universe to an event 
at once in time and unmediated by time. We have been able to see also that the root of error is the same in both cases - the imperative call of human experience for self-satisfaction, baulked, however, by unawareness of the precedent conditions. By its very nature, no mathematical computation can compass the ethico-religious consciousness. By its very nature, no unit incidental to an irreversible order can pose as quod semper, quod ubique, et quod ab omnibus. Specific historical events command credence only on specific historical evidence; and personal religion has no measure in common with such events. We must insist over and over again that the religious object cannot be prisoned within the integument of historical science. Yet Christians have cherished the supposition that they would find it here more completely than elsewhere. The consequent puzzle pays but another tribute to the immanent process that governs the preëstablished discord.

We are driven, therefore, to "try the great ocean" of the ethico-religious consciousness itself. Mayhap we shall fare better; for, if no more, at least man has illustrated the activities most characteristic of his peculiar being on this limitless area. Perhaps, we shall discover reason to conclude that, while all 
that is temporal exists, not all that exists is temporal. If so, we ought to be in a position to transcend 'exact' history. Perhaps, we may come to understand that the future, rather than the past, sets the norms of the religious career. If so, we might be able to regard causal reference in time, not as a negligible quantity, incleed, but as a subordinate function. 


\section{LECTURE VI}

THE ADJOURNMENT OF WELL-BEING

Any one who has tried to reach consistent ideas on the thorny subject, would agree readily that the ethical consciousness presents grievous difficulties. Its elusive movement seems to mock with subtler irony, the more faithfully one follows. And, if this be true for the careful student, who aims at a unitary construction, it strikes home, no less sharply, to the ordinary observer, or actor, in common life. Customary affairs of conduct produce numerous dilemmas from hour to hour. How often the decent citizen finds himself in a strait between two, and asks, Who will show me the good? Baffled thus on both sides, which together exhaust the field, small wonder that we should hesitate when compelled to seek a point of departure for our enquiry. Moral situations afford few decisive hints, thanks to their differentiated multiplicity; moral philosophies turn out so various, and so personal, as to furnish no foothold satisfactory to all. By good 
luck, however, especially in the present connexion, religion itself has been prone to display an unmistakable attitude towards the relative value of the moral life. 'Moreover, whether we select religious theory, as illustrated in theology, or religious practice, as followed by the Church, this disposition makes itself felt, with significant consequences. Here, at all events, our feet touch solid ground. Accordingly, I invite you to approach the ethical consciousness by way of two questions, put into our lips by religion, not least by Christianity. In the first place, Why have the ethnic religions tended more or less strongly - but tended quite plainly on the whole - to relegate moral conduct to a plane of secondary importance? No doubt, none of them dismiss it as if it were negligible; often they stress, even strain, it - we have all heard of "the Law," and of Christian Ethics. Nevertheless, it hardly ranks with "the one thing needful." In the second place, Why has the Church met such movements as 'Ethical Culture' with active hostility, or with impatience, or with almost open contempt? Or, coming down to date, Why do so many religious folk shake their heads troublously over that recent development baptized, by a delightful pleonasm, the "institutional church"? Were all these 
modern phenomena merely fresh eddies on the broken surface of our evanescent day, they might signify little. But it seems unquestionable that, after religion has attained a certain stage of selfconsciousness, has grown aware clearly of its distinctive nature, this attitude settles into a permanent characteristic. Nay, evidence could be led for the thesis that, in proportion as religion realizes itself adequately, the subordination of the ethical standpoint receives emphasis. Pray note, I am not raising the problem of the ultimate relation between religion and morality. I am only drawing attention to the patent fact, that, in its large sweep, religion tends to regard moral conduct as of inferior importance to something else - what, we need not enquire just now; and that, as religion reaches completer expression in degree, this inclination appears to become a regulative factor in its explicit outlook. Sharpened by these pregnant hints, we may start - fairly enough, I think - with the question, What justification, if any, has religion for such procedure? Obviously, all things considered, the situation warrants not a little curiosity. For, why should religion behave superciliously to morals?

At the outset, it must be understood distinctly that religion does not censure the moral life, but 
rather denies its authoritative validity within some regions. Kinship is admitted; and it were advisable to dwell on this aspect of the case for a moment. Family jars often go deepest, intimate most. A doctrine, by no means extinct to-day, teaches that, while morality may defy explanation, we can reduce it by explaining it away. That is, one can run it back to physical and physiological causes; this done, its peculiar importance disappears with its independence. Summarily, it possesses less reality than other parts of experience, because a derivant, not an original, self-witnessing activity. Recall, then, that even the dubious attitude of religion, now under consideration, never supports this topsy-turry notion. Rightly so. For it requires no argument to confirm the self-evident proposition, that one portion of experience is no more, and no less, real than another. A man's moral career constitutes a fact to be reckoned with just as much as his chemical or historical knowledge. Chemists and historians must encounter problems of conduct like their fellow-men. All effective components of experience, surely, are effective components. To enquire which are more real is to put a nonsensical query - one that corresponds to nothing of importance for an experient. Religion 
has never committed itself to absurdities of this sort in its commerce with morality. In our complex existence, the reality of moral issues and their dilemmas counts equally with that of intellectual theories and their demands. Both occur, and here the matter ends, as concerns institution of odious comparisons. Accordingly, we infer that religion has not minimized morality, because it may be a by-product of superabundant bile or of superior pancreatic juice, but for a far different reason.

Nor is this all by any means. Another, and more weighty consideration claims attention. As we have seen, 'exact' science and 'causal' history prefer specific conditions, which must regulate their material, if scientific and historical results are to accrue. If you recall them, as summarized in the last Lecture, you will observe at once that none apply within the religious life. For example, religion submits to no enumeration in time, or measurement in space; and it eludes retention in mathematical formulæ. Similarly, it never manifests itself in a continuous, but always in a discontinuous, series. It were a work of supererogation to take the dimensions of faith in cubic centimetres, or to calculate the efficacy of prayer by the parallelogram of forces. Now, the moral life stands twin 
to religion here. Just as the parallelogram of forces may be employed with equal facility in astronomy and physics, so other standards of judgement -

"How sad and bad and mad it was -

But then, how it was sweet!" -

apply readily in the ethical and religious spheres alike. So, if nature be an elliptical name for one kind of order, conduct and belief proclaim another. The conventional phrase, 'physical science,' carries unequivocal signification. For the unprejudiced student of human experience in all its aspects, the phrase teleological science ought to be no whit less clear. Any investigation of moral and religious phenomena is teleological. The material under scrutiny compels this description.

But the term 'teleology,' like others of its kind, has descended to us encompassed with naïve associations. We must reckon with contemporary usage, in the same way as we no longer attach the Greek sense to 'nature.' Therefore, to avoid misconception, especially on the part of our naturalistic friends, who accord curious, if telltale, importance to Paley, we shall try to explain it. When one calls ethical and religious events teleological, one proceeds in the same way as the scientific man when he classes 
physiology, histology, or cytology under the concept 'biological' - neither more nor less. The implication is this: They come full of material characterized throughout by fundamental differentiating qualities. No objection lies against the one word; similarly, no objection ought to lie against the other. Yet, misfortunately, teleology was "born out of time," and preëmpted. It used to signify purpose injected from without, especially from above. A superhuman agent had insinuated a plan into the eye, say, just as the optician had constructed the telescope with a purpose in view. It were superfluous to record that, in the present state of knowledge, no circumspect thinker hints such reference, any more than he posits vitalism in the term 'biology.' He means simply that the group of phenomena evinces certain qualities by its very existence, and that, without them, it would not conform to its known nature. Further, a teleological event need not be less amenable to explanation by self-reference than a mechanical one. Indeed, from the standpoint of any enquiry within human competence, they occupy the same level in this respect. Man may search most various topics, he must state them all in terms of the human equation.

As the issue bears directly upon our whole subject, 
we stop to ask, What emerges from it? In the first place, as noted in the last Lecture, the linkage between the members of a mechanical series is invariable and identical, no matter what differences separate terms may disclose on the surface. We are aware that the vibrations of a tense string, and the discharges from a Leyden jar, propagate themselves in the same way. Vie are able even to devise experiments such that the proof receives ocular demonstration - nodes and antinodes can be seen in both cases. And we are sure that the same regular disturbances happen in an organ pipe. In ethics and religion this stable identity fails.

"Outside should suffice for evidence: And whoso desires to penetrate Deeper, must dive by the spirit-sense No optics like yours, at any rate!"

A unique activity, one incapable of prediction, discloses itself and, thereafter, the series undergoes transformation, thanks to its presence. The reference runs forward, not backwards. In other words, we meet a situation such that causal dependence must be abandoned, if we would reckon with the manifest facts. Apply causality, if you will, but remember that, whatever its convenience, you have committed yourself to the tender mercies 
of a misleading analogy. Take, for example, the process known as conversion, whether moral or religious. A man has passed years in solid contentment with the conventional standards of his profession, class, or nationality. At length he "comes to see things in a different light." His scale of basal values vanishes - rank, wealth, influence, what not, "appeal to him" no longer. He has become a devotee to scientific research, mayhap. His old friends cease to comprehend him, he behaves so queerly. In such a case, we have the outbreak - never inbreak - of the new activity typical of the teleological, and therefore discontinuous, series. No design by anticipation, special to just this end, is implied necessarily even from within; much less has aught been injected for the specific purpose from an external, supernatural source. But we do find a revolutionary qualitative difference - the very thing abhorrent to 'exact' science and 'causal' history. Were they to embrace these phenomena, they would commit suicide. Nevertheless, an angle of intellectual vision enjoys no patent to remove or obliterate facts. Adopt what standpoint you please, these affairs happen to be effective components of human experience. Put in cold words, pale shades of the 
process in concrete, this "is a hard saying." Yet it embodies a group of normal events in the career of every man who has sojourned in the valley of veritable moral or religious trial. "Verily, verily, I say unto thee, Except a man be born again, he cannot see the kingdom of God. . . Marvel not that I said unto thee, Ye must be born again. The wind bloweth where it listeth, and thou hearest the sound thereof, but canst not tell whence it cometh, and whither it goeth: so is every one that is born of the Spirit." 1 These verses record the whole story in familiar language.

It remains to emphasize the fact that such incidents designate themselves no less distinctly than space and time variables. They possess their peculiar modes of existence and preservation. If the continuous series be a quantitative sequence, the discontinuous exhibits a self-consistent unity, dominated by a forth-reaching ideal. And this ideal announces the free dictation of the end that renders the compacted events teleological.

"How inexhaustibly the spirit grows!

One object, she seemed erewhile born to reach

With her whole energies and die content, -

So like a wall at the world's edge it stood,

1 John iii. $3,7,8$.

$\mathbf{R}$ 
With nought beyond to live for, - is that reached? Already are new undream'd energies

Outgrowing under, and extending farther

To a new object; - there's another world!"

We are confronted here by the concerted surprises of a self-developing system, never by uniformities of external adjustment, traceable to the nexus of adjacent agencies. That is, we have a type of individuality maintained throughout a qualitative series. Apply mechanical judgements, if you like; they disclose nothing but paradox. You may abstract from the qualities, if you so choose, - to obtain 'causal' history, for instance. But you must bear in mind that you have chosen to eliminate, and that elimination produces no change in the original factual totality. You are not studying the given group in its proper reality; you are dealing with it for a purpose of your own, foreign to the data; you are not essaying an explanation of the case as presented. Accordingly, we seem entitled to conclude that, if we are to penetrate human history, to pierce beyond its outer framework to its actual process, we must class its phenomena with those of ethics and religion. At best, 'causal' history, the bootless search for origins that disturbs pious souls, cannot amount to more than a preparation - 
a necessary one, surely - for appreciation of the spiritual temperament in its concrete entirety. For the historical series, as human, cannot be less discontinuous than that of ethics or religion. To state the naked case, cause functions subordinately in history, for there we must deal with a succession of events, so constituted empirically, that the modifications are historical only because motivated by fresh outbreaks of ideal activity. The occurrences that carry history belong invariably with conversion, and not with a lever, a spool, an arch, much less with the precession of the equinoxes. If you so desire, you may think of them as an ethical interplay; assuredly you can never dub them a mechanical arrangement, except by deliberate suppression of the very facts you have undertaken to grasp. No doubt, one may dismiss factors for a preliminary purpose. But persistence in this partiality reduces its sponsor himself to the level of a preliminary phase. He serves himself a hewer of wood and drawer of water for the constructive genius whose insight aspires and joys, bleeds and burns with the palpitating past, regenerated into the present.

Lastly, one other point of agreement between religion and morality may be mentioned in passing. The practical reference predominates strongly in 
both. They keep with the daily round of ordinary life, rather than with abstract theories about life or the physical universe. Man lives them out.

Our analysis, then, reveals a substantial basis of unity between morality and religion. This renders the 'superior person' attitude of religion the more surprising - and interesting. So we revert to our former question, Has religion any justification? I think we cannot avoid an affirmative answer, and for a reason that roots in profound truth. Moral endeavour ends ever with the adjournment of wellbeing. Thus, the position where we find ourselves now may be described as follows. Competent and successful within their respective ranges, quantitative science and positive history furnish no guidance when an account of the universalizing quality peculiar to human nature stands in need. The tendencies of contemporary culture prove that, when baulked in this way, men turn to the moral life, only to find, on the suggestion of religion, that it, too, suffers limitation. Perhaps it offers another example of the preestablished discord, though of a new and disconcerting kind. Possibly Burns, that master among those who search the heart, was right when he wrote, -

"Misled by fancy's meteor-ray,

By passion driven; 
But yet the light that led astray

Was light from heaven."

Evidently, we must ask, How far is this true, and what message, if any, does it bear about religion itself?

Although it may be theorized, the moral life is practical in the first instance. It manifests itself in overt action, the deeds of individuals. These, again, issue from highly complex antecedents, whose nature we indicate by calling them 'ethical.' This, in turn, carries a social reference. Nothing counts as ethical unless it involve an ethos - the internal spirit generated by, and peculiar to, an intensive group. Suppose we take an American citizen, and proceed to strip him of his ethical possessions. Deprive him of all that he absorbed from his immediate family; of the influences that flowed in upon him from the environment of his boyhood and youth - north, south, east, or west; of all that he derived from his training in the common schools, and other educational institutions; of the precepts imposed upon him by, say, the protestantism of the sects that permeated his neighbourhood; of the associations formed midmost the political and economic outlook of the United States; of the judgements he learned unconsciously from his daily reading in newspapers and 
popular magazines; of the perspective gained from the social ideas shared by him with his countrymen; of the movements special to the climate of opinion at the dawn of the twentieth century. Next, having subtracted all these, ask, What is left? The reply comes, swift and decisive, We not only do not know, but have no means of knowing. Apart from these reticular, excessively subtle, dispositions, nothing can be said of the man, or of any man. In other words, a mere naked individual never existed; and the more complex the civilization wherein a human being has partaken, the more profound this truth. The moral life persists only as at once the expression and the agent of transmission of such psychological unities. It might be described as a process of oscillation between a society and its members. Moreover, the personal career displays significance, gains enlargement, becomes valuable within the group, just in proportion as the universal spirit overflows it. A man has morality, because possessed by it in everything that lends him importance. "Hence," as Hegel wrote, "the wisest men of old" - by whom he meant Plato and Aristotle, our chief ethical authorities still - "have adjudged that wisdom and virtue consist in living in conformity with the ethos of one's folk." Culture- 
history enforces this truth overwhelmingly. The paragons down the ages have been precisely those who lost themselves in their dominant social norms, or who attempted to emphasize relations slurred by the contemporary spirit. The conformists, acting with, the reformers, reacting upon, an organized ethical unity, together constitute the elect representatives of morality. Nor is the reason far to seek. In such circumstances, external rule gives place to inner principle. Thus inspired, the real types of the society illustrate moral activity in its most favourable light. For judgement can reach sharp decision in particular difficulties. Nay, the more important the choice, the less the hesitation to be encountered. Almost instantly, prompted by his cultural ethos, the 'well-bred' person knows what to do. The 'ought' shines clear, and passes to 'is' forthwith. So, without the genial support of a diffused consciousness of kind, morality has usually withered or wavered. An epoch of transition and an era of simplicity, marked by 'originals,' seem equally unfavourable to ethical achievement. In the one, the social ideal is at odds with itself; in the other, individuals, free from direction, are apt to lapse into curiosities. The unity loses its balance in duality, or pluralism. "Social life is to personality what language is to 
thought." When it is said that a nation is merely an aggregate of individuals, "the fallacy lies in the implication that the individuals could be what they are, could have their moral and spiritual qualities independently of their existence as a nation." 1

Now, the inference, consequent upon these evident facts, offers a very relevant reason for the distaste of religion to the adoption of 'works' as an ultimate test of worth. Let us put it in this way. Granted that the ethical problem can find solution only in practice, and granted that a social ethos gives the environment necessary to this practice, what follows?

First, something favourable to the ethical claim. The antithesis between egoistic ideal and altruistic realization tends to abate its acuteness - achievement treads the heels of aspiration most closely in the recompenses obtained from voluntary unity with the great aims of one's racial or national spirit. When the Roman stiffened his backbone and said, "Civis Romanus sum," he was the embodiment of what, in all fairness, we may call moral attainment. So is your modern American or Englishman or German, - he who feels he must be reckoned with on account of his people, and realizes his own responsibility in measure. When personal desire

${ }^{1}$ Prolegomena to Ethics, T. H. Green, p. I93; Ist ed. 
finds itself completed in the best that bore it, then, and then alone, possibly, something in the nature of a moral hearen has been reached. For the solitary soul stands transfigured, and, having united with the many at the benign moment, serves itself 'great' ethically. In their songs, when breath comes short, and tears start, men apostrophize no physical land, but a spiritual state. "My Country, 'tis of Thee," "Die Wacht am Rhein," and the rest, reek with pride, but not pride that goes before a fall; far rather, the pride that ensues upon real elevation. Detach the good from materialized associations, and you may say fervently, "Ubi bene, ibi patria." Here, if anywhere, "eternity is in love with the productions of time." Here, if anywhere, the incalculable power, and the bewitching graciousness of the ethical appeal abash us into silence of consent by their glorious success. Here, if anywhere, we must find justification for the recurrent choice of goodness as the ultimate measure of a man. Glancing back at her work, morality might adopt, and flaunt, the Christian motto, "Die to live." For the genuine uplift of a folk has never been sought vainly in the ensamples of its own soul set before it by its sainted representatives. The revelation of the animating principle of a communal ideal, its concrete 
embodiment in a devoted, but sane, character, were, surely, something whereon anyone could dare take his stand "at that great day," expectant of the good servant's reward. Self has forgotten self and, through this very loss, has grown into the image of a near infinity.

"The grosser parts fly off and leave the whole, As the dust leaves the disembodied soul!"

Accordingly, we think of our 'heroes' and 'representative men,'-

"The dead, but sceptred sovereigns, who still rule Our spirits from their urns,"

as if they belonged to a region where Time, with her waters of Lethe, exerts no spell. Thus, the claim of the moral consciousness to erect a court of final judgement has always received popular suffrage, offered frequently a convenient, and even salutary, recourse. But, notwithstanding its splendid title to human allegiance, and the stimulating intensity of its attractions, the preëstablished discord haunts it. Put it to the question, and you will discover that its last word cannot but be the adjournment of wellbeing. Of a truth, it transports one to "an exceeding high mountain," but only to point the higher, inaccessible, peak in the blue beyond. 
For, second, its most adequate solutions, even at their radiant best, must keep the level of stages in the course of eulture. While no prayer may be uplifted with more assurance, while none may be more thoroughly worth benison, than "the work of our hands, establish Thou it," still the truth remains that the work is $a$ work, and the establishment possible only under eertain limited conditions. "They shall perish, but thou shalt endure; yea, all of them shall wax old like a garment; as a vesture thou shalt change them, and they shall be changed." 1 So religion maintains. And why? Look at our American civilization, for example. To the ethos of Greece we owe the humane element - overlaid sadly in our free spirit; to the ethos of Palestine, transmitted through Reformation Germany and Puritan England, our religious quality; to the ethos of Rome, reborn in the genius of Britain, our common law; and other factors to I know not what forces of institutionalism, consecrated in alien climes, and older epochs. Nevertheless, we contemn Greek and Latin for 'dead' languages, and grin over our 'progress' when we banish them from our schools; we exclude the Bible, and prink ourselves in 'unsectarianism'; we shiver at the very name of Roman imperialism,

1 Psalms cii. 26. 
especially if we are of those whom the breezes of the North Atlantic chill; we flout the 'effete' civilization of England, particularly as incarnate in its governing class wherein, most characteristically for the modern world, the perfection of balance between individual aspiration and social achievement - the completest solution of the unlaid ethical problem - is to be seen. And for what reason, please you? Is it the most grotesque of provincial follies, or an unamiable foible of sheer ignorance? Not at all. The answer is, Because we cannot help ourselves - the morality of no one of these stages satisfies us. ${ }^{1}$ The root of our superciliousness strikes deep in our own hearts. From the height of our civilization - which is a height only as it is ours - we look down with pity upon all these, just as they severally scorned 'barbarian,' 'heathen,' or 'outsider' in their flowering time. "Thou art weighed in the balances, and art found wanting." This writing on the wall demands no astrologer, Chaldæan, or soothsayer "to make known the interpretation thereof," much less "the excellent wisdom" of a Daniel come to judgement. The conclusion runs plain. Universalize any solution morality can offer, and it becomes false forthwith, self-contradictory, or even a cumberer of the ground.

${ }^{1}$ Cf. Joshua xxiii. 4-I3. 
"The spacious days of great Elizabeth" could not have been spacious had they stood quod semper, quod ubique, et quod ab omnibus. The moral life may indeed win to a goal once in a day. No matter. For, by its inmost constitution, it effects so much in that day, and in that day alone. The very perfection of the unity between ideal and aspiration serves but to originate a fresh opposition between the part that is and the all that ought to be. The English gentleman - Lord Cromer will pardon my impertinence in citing his representative record of tenacious rectitude - may very well be one of the finest examples of ethical completion the world has known. Yet, callow though it may seem, we mock him, because his 'ought' either fails utterly to appeal to us, or even assumes the ugly shape of an 'ought not.' In brief, the ethical consciousness must circle $a b$ urbe in urbem; it can never speak ad orbem.

"Framed for the service of a free-born will,"

the highest manifestation of moral well-being, and well-doing, no sooner walks the earth than adjournment is taken, to tear it to pieces in committee, as it were. It was framed. Ethical realization wrought, as it must be, under stringent conditions, reveals itself as a kind of magnificent failure, when conditions 
alter never so little. Nay, the more its magnificence is lauded, the more its failure tends to incense those whom the magic circle excludes. Confined to a place or people, exuberant in a circumscribed period, the moth and rust of this world break through, and lo, it has gone to destruction.

Here, then, we light upon the reason why religion has often cast suspicion upon 'works.' One good custom can corrupt the world, because morality is predestined to end in a series of compromises. Has the 'immoral' man been detected invariably in sot or sensualist, and in none other? By no means. As often he has horrified the "great and good ones of the earth" in the guise of a graceless iconoclastpounding at the foundations of their consecrated usages. What else was Jesus himself? Was he not "possessed of a devil"? To

"Hold infinity in the palm of your hand, And eternity in an hour,"

is not given to morality, because -

"Pity would be no more

If we did not make somebody poor, And Mercy no more could be If all were as happy as we.

"And mutual fear brings Peace, Till the selfish loves increase; 
Then Cruelty knits a snare, And spreads his bait with care.

"He sits down with holy fears, And waters the ground with tears;

Then Humility takes its root Underneath his foot.

"Soon spreads the dismal shade Of Mystery over his head, And the caterpillar and fly Feed on the Mystery.

"And it bears the fruit of Deceit, Ruddy and sweet to eat, And the raven his nest has made In its thickest shade.

"The gods of the earth and sea Sought through nature to find this tree, But their search was all in vain:

There grows one in the human Brain."

This is "the human abstract," as a profound genius in mysticism saw so clearly. The 'ought to be,' the completer it 'is,' earns the frown of the 'ought not'; and so man passes from likeness to likeness of the good, particularizing from age to age, but universalizing never. Well-being truly arrives, but only on agreement that it adjourn, the sooner the better, to give place to well-being! Small wonder that many seers and poets, astray in the ethical maze, should 
have likened human existence to a pragmatic cycle, arising, spreading, embracing, vanishing, merely to return and repeat itself in the same empty ceremonies, world without end.

Time forbids me to dwell in detail upon the contradictions and compromises easily discoverable by any thoughtful person in the current standards of his own ethical environment. Suffice it to say that, thrust back where deepest satisfaction might be anticipated, mankind appeals to religion. The adjournment of well-being forces this alternative. We yearn for assurance, and are bidden - to keep up the struggle. Therefore we seek another country, which is an heavenly, in the hope that the peace that passeth understanding may dispel uncertainty. Great as is the fallacy that seeks universal explanations from positive science and 'exact' history, the attempt to cxtract comfort from 'ethical culture,' or to escape religion by recourse to institutionalism, may be falser still. Science and history we know, but this assumes the dangerous guise of an enemy within the gates. So, in conclusion, we approach common representations of the religious consciousness, to see whether we shall fare any better at their hands.

Taken on its practical side, especially, the moral 
life appears as a restless and, sometimes, confused state of effort. It demands a curious union of perseverance and concession. Even when it reaches comparative stability, in a distinctive culture, disquiet dances close attendance. In all likelihood, we must agree to accept these limitations as inevitable; circumstances compel us; otherwise, morality would not exist. For, in practice, men are finite beings, subjects of a spatial and temporal order. They exhibit morality, because they cannot escape the fetters of their mortal lot. Yet, on the contrary, they could scarce maintain an endless struggle, sure of its futility, last and first. Despite appearances, they affirm, by their very alacrity, that their persistence through the strife witnesses to copartnership in a mission destined to final success.

"Grow old along with me!

The best is yet to be. . . .

"Rejoice we are allied

To That which doth provide

And not partake, effect and not receive!

A spark disturbs our clod;

Nearer we hold of God

Who gives, than of His tribes that take, I must believe."

The nature of the system - 'spiritual' plus 'material' - wherein man subserves his function as an 
258 MODERN THOUGHT AND THE CRISIS IN BELIEF

ethical being, thus comes in question. Practical though morality be, it is also systematic, and therefore presupposes constitutive principles. It proceeds on a basis little distinguishable from faith. The relevant motive-force, so to speak, involves decided convictions. As science postulates, without proof, that this frame of things is rational, and rational in such a way that the human intellect can grasp and use it, so morality, nothing loth, lays down initial propositions peculiar to its 'universe.' Stated briefly, even baldly, they are as follows: There would be no moral life unless man felt that, in sum, character attains enhanced power and fuller expression in ethical activity; and that, more rather than less, the consequences of endeavour represent victories whose benefits cannot be lost. Now this intimates that the practical career issues from an ideal insight. A new light suffuses the harsh disappointments of common day. We discover a time-process, foredoomed to failure in every particular case. Yet we must face the correlative fact that this process justifies itself, and anticipates its own completion, by reference to a perfection seen with the eye of faith only; even foolish mortals avoid a course where certain disaster is demonstrable beforehand. Were this ideal world to become real, however, morality would be 
abolished as ipso facto inconceivable or superfluous. Nevertheless, the existence of ethics betokens the conviction that this ideal possesses ultimate meaning. Hereupon morality has abdicated in favour of religion. For religion pivots on the belief, not that these insights merely hint some vague eventuality, but that their object is the sole actual existence. The very imperfection of the moral life involves appeal to that supra-ethical reality which religion terms God. In short, another view of the entire system of experience looms in sight. The immemorial minor contradictions of diurnal affairs reveal a major contradiction between possibilities, known to be of one kind, and a present reality, conceived to be of totally different kind. For morality is a realization of human nature, just like any other-digestion, say. It offers a partial disclosure of a broken unity. Religion, on the contrary, seeks unequivocal realization of the unity as a whole. But this seems entirely impracticable, because complete realization must include the ideal insights which, in turn, cannot find room within the realm of finite being, cribbed, cabined, and confined in a temporal series.

This inexplicable disharmony shows us why even so great a religious genius as Augustine felt constrained to speak of life as "a monstrous para- 
dox." Take him from any side you please, man is himself a huge contradiction. "What a piece of work is a man! How noble in reason! how infinite in faculty! in form and moring how express and admirable! in action how like an angel! in apprehension how like a god! the beauty of the world! the paragon of animals! And yet, to me, what is this quintessence of dust? man delights not me, no, nor woman neither." No profounder difficulty assails reason, faith, and hope. Art represents Jesus with a crown of thorns, Nero with a chaplet of roses; she omits to add that the thorns blossom into roses, that the roses fade into thorns. Which picture holds truth? Or, are both true? Or, is there no truth, after all? We must not anticipate that an otiose, heritable conception of religion will avail much against problems like these. Nay, if we muster courage to play the game squarely, we must rather expect to discover that, sometimes, religion itself falls within the grasp of the wholesale contradiction. For, were it merely a transient from a distant clime, it would lack the touch of nature that makes the whole world kin. So, on any count, if it can effect aught to deliver, we are bound to view it as incidental to man's universe, and therefore as a subject of the preëstablished discord. We dare 
not go forward in blinclness to even the strangest turn of the wheel. If life be a paradox, and if religion be its inseparable accident, our holiest Edens cannot escape the trail of the serpent. In some aspects of it, religion, which "builds a heaven in hell's despair," also "builds a hell in heaven's despite"!

The controversies that still surround the word afford abundant proof, not necessarily that its meaning is doubtful, but that it may be interpreted in various, perhaps mutually exclusive, senses. Speaking generally, we know Religion as religions. While, condescending upon further detail, several conventions affect our apprehension of any one religion. The prism of experience splits the pure white light into many coloured rays. This weird contingency will claim our notice in what remains to-night.

Customary associations control our uncritical acceptation of many abstract words. Linguistic denominations, like thousand-dollar bills, pass current at their face value - we do not think of the cents, much less of the reasons for the numerous, and shifting, exchange-worths represented. In short, the sign is presented or taken with an indistinct consciousness of its meaning, or without reflexion, or with positive error. Further, as civilization grows more complex, and portions of life gain rela- 
tive independence, this tendency to symbolize waxes mightily. If one were to pull a friend up short, with a request to define 'Government,' 'State,' 'Constitution,' 'Commerce,' 'Jurisdiction,' and so on, the exact constituents would not be forthcoming in every case. As for these, so for 'Religion,' it is easier to rest in a customary import, fixed by usage in a given society. Regarded thus, religion tends to symbolize one of several things as a rule. And, when you have heard the list, pray ask yourselves this question seriously: When these accompaniments have been stated, how many of your acquaintances and neighbours could you name who do not conceive religion to consist in one, or in a combination, of the views mentioned; and, if they be inadequate, what then?

(I) Religion may be identified with the government, order, and practices of an institution - an ecclesiastical organization, say. All these, once more, vary from time to time, from place to place. Racial and cultural tendencies mould, if they do not control, specific manifestations of the kind. (2) It may be identified with a system of doctrine. Here, again, racial and social tendencies intervene. One people may be so constituted psychologically, or its stock of knowledge may be so crude, that its creed 
counts no more than superstition with a folk in a different stage of development. Nay, within the same nation, the belicf of one group may seem folly to another. (3) It may be identified with peculiar events alleged to have broken the normal current of history. Here, yet again, racial and social predilections play an immense part. Jesus, a child of the Orient, was destined to conquer the West, but, equally, to miss formative influence in the East. Recall, too, that the religions which rule humanity to-day were all of Oriental origin. The Occident has evolved science, invented machinery, built battleships - and christened them in the name of the God of love by His consecrated ministers; she has never created a great religion, unless, indeed, Christianity be credited to her. Accordingly, it requires little perspicacity to observe that, in all three cases equally, the compromises, even contradictions, characteristic of the moral consciousness, appear on the scene, with the usual consequences. The adjournment of well-being presents itself in new phases of its protean shapes.

(I) It would be fantastic to assert that an institution, developed in the course of history, could be universalized so as to provide a fundamental explanation of experience. All institutions exist to 
subserve practical ends and, on this account, they fail us when we seek consistent theory. To use the language of religion, no one would allege that the visible church and the kingdom of heaven are identical. The church appeared, and still continues, as a means under the form of time; we are bound to conceive the kingdom of heaven as a perfect community under the form of eternity. Thus the question arises, Can any religious organization escape the limitations that cling to all incidents in a temporal series? The attitude of anti-religious rationalists, and their reasons for it, prove the negative. Critics of the church fail to perceive that the dross of time and space defies the refiner's art; or they blink the situation wilfully. They return again and again with disagreeable charges. They draw lurid pictures of the apposition between profession and practice; they wax mordant over the shallow compromises forced upon the church by the flesh and the world - by moral conventions, by the economic order. Doubtless, lively prejudice jaundices their vision frequently. Nevertheless, one may as well admit that they appeal to notorious facts. Still, their abuse derives its sting from the assumption that the church represents heaven upon earth, that it furnishes a complete epitome of the 
religious consciousness. If they were careful to recall that it is no more than instrumental to the major ends of man's being, their capital would be gone. As one type of human organization, it must submit to influences which no leap of imagination can transfer to an ideal community. Whatever man may become sub spccie atcrnitatis, we have every reason to believe that he will not remain what he is now sub specic ccclesic. In worship, for instance, we make common cause with some whose characters we despise; and the same holds of other churchly activities - we may have to serve with them on a vestry. So far as our present partial insight reveals, we are perfectly certain that these relations would render heaven a mockery. Yet they bother us on every hand in our temporal expedients. We compromise with them, and contradict our highest aspirations, because we are unable to help ourselves. Nor does the paradox finish here. The compromises and contradictions are tolerated for the sake of these very aspirations. They are tools, placed in our hands, willy-nilly, here and now.

"Can wisdom be put in a silver rod, Or love in a golden bowl?"

Assuredly not. Yet, straightway, we proceed to cramp them thus. In short, the visible church, as 
an apparition in time, bows its head in consent to the adjournment of well-being. No doubt, in separation from such societies, we may fall upon greater defect than when joined with them. But this lends no colour to the naive idlea that the bare fact of association embodies an adequate ideal. Briefly, the church, because ordered thus and so in the past and present, necessarily lags behind the very spiritual fulness that it exists to proclaim. To quote a commonplace of sarcasm, we ought to remind ourselves constantly that, under temporal limits, the thirteenth vote represents the Holy Spirit only too often. Here Fate touches our workaday world with the grim humour of truth; and, within her own borders, we must abide her awful irony. A temporal organization sways from side to side; otherwise it would die, for the tortuous movement attests its vital quality. This same record of contradiction forms an indispensable stage in our 'progress' to anything ideal. No matter with what fine qualities we credit our instrument, especially when first made, sooner or later the inherent deceptions will come to light. This is the law of $\sin$ in our members. Indeed, one need not go further than the apostolic writings for lambent illustrations of the hapless truth. Vacuous fatuity and smug self-assurance beset religious 
institutionalism. They tell the price payable for ideal symbolization in objects that sink easily to the unideal. The poor are always with us; but, worse luck, so is Seth Pecksniff. "'There is no deception, ladies and gentlemen, all is peace, a holy calm pervades me.' .. His genius lay in ensnaring parents and guardians, and pocketing premiums. ... We are all hypocrites. . . The only difference between you and the rest . . . is . . . that you never have a confederate or partner in your juggling; you would deceive everybody, even those who practise the same art; and have a way with you, as if you - he, he, he - - as if you really believed yourself. I'd lay a handsome wager now, if I laid wagers, which I don't and never did, that you keep up appearances by a tacit understanding, even before your own daughters here."' Thus it must ever be with a temporal construction. Convicted of shortcoming, it abases itself before the ideal, and, at the same moment, puffs itself up with false pride, flaunting the presumption that the ideal can find habitation nowhere else. Evidently, then, we must not seek for complete satisfaction of the religious consciousness in the visible church. A round of pietistic ceremonies, so called, is no more religious than a round of devotions to duty - the 
mother's, physician's, patriot's, scholar's. Only when mediated by that tension of the whole man which we term religion do these practices and selfsacrifices acquire religious import. Therefore, to mistake the church and things ecclesiastical for religion is no more than a concession to the world, likely to be fraught with disappointment, pain, or, perhaps, disaster, when real stress arrives. For the religious consciousness looks to the invisible things of a timeless perfection. Nay, would not the church become actively irreligious - has it not actually been so in times past - if it did not demand something higher than itself? If we remember this, I think we shall escape unscathed from many difficulties that worry good souls to-day.

(2) Similarly, even granted that religion requires an irreducible minimum of doctrine, it is plain that the system proceeds from the human mind. Consequently, doctrine occupies precisely the same position as any other pronouncement of reason. It is at bottom a series of hypotheses, evolved to account for certain ebullitions of inner experience; it cannot pretend to complete truth. While it may be matter of immense practical importance that groups of men possess the conviction that some spiritual asseverations are true, this means only that 
they find them helpful. In other words, the relative character of knowledge always infects single propositions, and never so emphatically as when an attempt is made to render them the sole vehicles of truth. When a Christian cannot explain to you why doctrine presents God as triune, and flies to 'mystery' for refuge, what can you expect as to truth? When a pious soul is unable even to comprehend why there cannot be any 'relation' between an absolute God and a separate individual like himself, how can we anticipate that he knows the truth about an 'atonement'? In short, dogma is either too simple or too sophisticated to be capable of universal application. Too simple, because it neglects to fathom the presuppositions of the complexities it undertakes to define; too sophisticated, because it winks the eye at man's undoubted power to destroy or alter his own conclusions at any moment. It is a mere piece of self-deception to suppose, for example, that we could not compose a more adequate creed to-day than in the fourth century. Yet we let the old statements stand, because, as I heard an ecclesiastic say once, "you can drive a coach and four through them." The point to be remembered is that you can perform this interesting feat upon any creed possible within the logical pro- 
cesses of reason. 'The secret ways of the religious consciousness defy all doctrinal anatomy. Moreover, doctrinal conclusions, when they suffice momentarily, are no more than reasons post factum. In a sense, every creed must be a forlorn hope. It rationalizes a condition which, in its very essence, cludes abstract reason. As a reflective, and secondary arrangement, it betrays all the usual defects of the hypothesis-tribe. And the curious error, that a series of set propositions, relative to their day and generation, must contain the whole truth of religion, amounts simply to additional evidence of man's reluctance to face thoroughgoing thought about spiritual things. This blunder, be it said in passing, has always been a characteristic of Englishspeaking protestantism. Our racial tendency to evade, or falsify, spiritual issues, is well understood by the continental peoples. ${ }^{1}$

1 The following is typical of the view held by the Latin peoples: "This race, bodily energetic and resolute like no other, is morally childish. Wonder and awe before questions unfathomable to the Englishman make him subservient, and establish the base of his mental discipline. In other races there is not to be found such respect for tradition, or worship of established forms, or admiration for great men, all the social traces that lessen the individual carat of genius, and so cement with solidity the whole mass of the greatness of the people. The English, who are penetrated by the Rationalistic civilization of the Continent, principally of German origin, confess that intellectual cowardice is the only 
A creed, then, is not religion. It is obviously a form of words, valid for those who fathered it, and intended by them to define some experiences believed to be incidental to religion. It is doomed to pass or change, just like any other theory, - in science, for instance, - and this because its content partakes in the relativity of its age. So, once more, if we would bear these things in mind, many difficulties that distress devout souls to-day would vanish into thin air. For a creed, like an ecclesiastical organization, is an instrument, and a most temporary one at that. To put it in place of its creator, the religious consciousness, is to invite needless misunderstanding, perhaps eventual apostacy. For, in the nature of the case, dogmas constantly become irreconcilable with known facts. And to insist that the religious consciousness accept falsehood for its portion appears, to some at least, suspiciously akin to the sin against the Holy Spirit.

kind of cowardice possible for Englishmen, but that lays hold of them to an excessive degree.... It is even yet difficult for an unbeliever to pass as a gentleman, a good Englishman, and an honoured man. Hence comes a custom that, without being positively a vice, is coated with hypocrisy - cant, the ritual of indestructible conventionality." The England of To-day, Oliveira Martins, pp. 94-95. Some would maintain that, in the protestantism of the United States, these conditions are even more accentuated. 
(3) Everyone knows, in a general way, that Christianity owed much to the religion of the Hebrews. Everyone knows also, I suppose, that Hebrew religion adopted a peculiar attitude to history. It selected particular events, limited in time, and endowed them with timeless significance. In short, innocent of causal sequence, it elevated physical phenomena to the level of supernatural manifestations. Or, more strictly, thanks to animism, historical sequents were transformed into dogmas they "had some unique influence on the relation between God and man." 1 This tendency passed over to Christianity, as the creeds show plainly, and historical occurrences, coming to be represented as transactions between the divine Being and humanity, assumed the character of opera operata. The consequence was a most unhappy union between two series of experiences, each amenable to wholly different kinds of judgement. Impossible, sometimes offensive or trivial, incidents, as history must count them, were thus forced upon Christianity as part of its permanent content. Accordingly, when scientific method annexed history, our religion could not escape assault, even impeachment. It had sunk

${ }^{1}$ Some Dogmas of Religion, John McTaggart Ellis McTaggart, p. 2. 
unwittingly to the level of causal sequence, and had staked its veracity upon temporal and spatial categories. Now, matters religious win to verification at first hand in the concrete consciousness of devout men. Yet here they were, jumbled with fiction-fact capable of estimate by none save trained specialists. Results guaranteed by the emotion, sentiment, and aspiration of living souls lost their force, because associated with antique stories at once dubious in themselves, and beyond evaluation by every average believer. Religious idealism, essentially metahistorical and metaphysical in character, was changed, by a Circean spell, into a localized emeute, subject to disproof at any time by critical investigation, by the discovery of fresh documents, or by novel archæological finds. Besides, the farther history goes, the more definite her methods, the surer her results, the worse the plight of a priori dogmatism. "If it is the methodic cardinal proposition of the science of to-day that we have to explain every condition as the causally determined development out of a preceding one, this excludes on principle the appearance of any condition, event, action, or personality which is not explicable out of the preceding conditions and according to the laws of genesis in general." 1

${ }^{1}$ Evolution and Theology, O. Pheiderer, p. 9. 
Moreover, as I have said already, this science has no more than reached lusty youth. "If thou hast run with the footmen, and they have wearied thee, then how canst thou contend with horses? and if in the land of peace, wherein thou trustedst, they wearied thee, then how wilt thou do in the swelling of Jordan?" " The position is so intolerable that misapprehension must lurk somewhere. Does our Christianity depend ultimately upon a profession of belief in incidents, some known to be imaginary and absurd, others likely to be exploded any day, or does it not? I fear we must reckon to learn that the former alternative is nothing short of an insult to our religion. It cannot depend upon a dead past, or consist of 'stuff' meet to be tossed in a blanket by scientific criticism. And yet, this is what many good folk are taught to deem indispensable by official defenders of the faith. The irony of it is unspeakable. Thus, if we could rid ourselves of this, as of the other secondary manifestations, we would escape much mental dispeace, much spiritual bewilderment, and, above all, we could conserve our religious strength for things which are of the last moment to our present personal lives. For, an event in history, subject to temporal bounds, must be delivered alto-

${ }^{1}$ Jeremiah xii. 5 . 
gether from this imprisonment - must cease to be merely historical, in short - if it is to acquire constructive significance for the religious consciousness. No one will fathom Christianity, for instance, till he realizes that the Gospels are not sober biographies, but cataracts of faith. But, if we will confuse religion with births and deaths whose very attestation is woefully fragmentary, and therefore obscure, we must not wince if historians maim, aye, destroy, our cherished faith. Nor can we be too clear that special pleading will avail nought to restore the shattered fragments. Once more the adjournment of well-being has overtaken us, and, if current signs intimate anything, in a form penetrating beyond all precedent.

It must be insisted, however, that, although morality, the church, creeds, and historical phenomena put us off when we seek ultimate satisfaction from them, they are not cast into the scrap-heap thereupon. Men would not tend to identify religion with an institution, a confession, or a beauteous character, unless they had some natural justification. All these serve, or illustrate, religion in so far as they offer fit sphere for the play of consecrated sentiment, touch it to fine issues, or conserve its hallowed associations. Indeed, such achicvements of the 
human spirit exert legitimate influence, and are surcharged with significance in degree only as emotion and aspiration pulsate through them. But to mistake them for a full, true, and particular translation of religion, as it wells up from the unplumbed deeps of psychical peace-in-strife, is to invite heavy penalties. They face towards things seen and temporal; it yearns towards the unseen and eternal. They localize this is their distinctive function; it tries to escape locality. They suffer constant change; it would partake of an existence that is the same yesterday, to-day, and for ever. Accordingly, the inevitable march of our own consciousness drives us from finite forms, useful, nay, necessary, in their order. From religions, and religious machinery, we are compelled to pass to Religion itself, in the hope that, by its strength, we may be delivered from the bitter disappointments wherewith the adjournment of wellbeing is fraught, thanks to the compromises and contradictions inherent in mundane affairs. We have followed the gleam from the first and, foiled, nowhere more than in its chosen representations, have missed the one thing needful. At all events, 'Christian truth' has eluded our search. And now it seems that if, haply, we are to establish any such vantage for experience, we must appeal to the reli- 
gious consciousness in its own proper nature. Possibly, we shall have to abandon Christianity as a religion, and essay the formidable problem, Does religious truth find its most eminent expression through any convictions concerning God in man defensible before contemporary insight? Or, more directly, Has 'Christian truth' such faithfulness to human nature that it can be regarded, not as an incident in, but as the ultimate expression of, Religion? 


\section{LECTURE VII}

\section{THE PENUMBRA OF BELIEF}

WHEN we take an inventory of experience, we are prone to ask, Where does it attain highest definition or assurance, where are its results least broken by misgiving? And we answer, with no uncertain sound, In knowledge, of course. The temper of the present age, more, perhaps, than even that of the scalum rationalisticum, the eighteenth century, harps on this view. As never before, men stand shoulder to shoulder, banded in a unitary effort to satisfy passion through knowledge, heedless of Faust's mischance. As never before, knowledge spells power, power to invade and exploit physical forces. Yet any investigator will tell you frankly - and the greater his eminence the more incisive his tone - that the conquests of settled knowledge form but a fragment, incalculably minute, wrested from the illimitable unknown. Mr. Edison has had the temerity to state the relation in terms of some inconceivable numerical ratio. On the impressive 
occasion of his professorial jubilee, surrounded by the world's leaders of science and learning, amid a hush that chastencel all who had the good fortune to be present, the late Lord Kelvin said :-

"One word characterizes the most strenuous of the efforts for the advancement of science that I have made perseveringly during fifty-five years; that word is Failure. I know no more of electric and magnetic force, or of the relation between ether, electricity, and ponderable matter, or of chemical affinity, than I knew and tried to teach my students of natural philosophy fifty years ago in my first session as professor. Something of sadness must come of failure; but in the pursuit of science, inborn necessity to make the effort brings with it much of the certaminis gaudia, and saves the naturalist from being wholly miserable, perhaps even allows him to be fairly happy in his daily work." 1

Here, observe, Lord Kelvin voiced what he knew, and did not venture upon any of his theological pronouncements, notorious, occasionally, for their wayward naiveté. Of a truth, we are immersed literally in secrets that lie beyond ken, whose very existence we do not so much as suspect, in all probability. At the same time, it would be foolish to

${ }^{1}$ Lord Kelvin, Professor of Natural Philosophy in the University of Glasgow, 1846-I899, pp. 70-71. (Glasgow, I899.) 
allege that the hidden processes of 'matter,' 'life,' or what not, constitute mysteries, or evidence a suprarational dimension. The whole body of science warrants the inference that the cosmos cannot be ultra-rational and remain a cosmos. Unreason makes its bed in chaos. Our being may seem mysterious, but only because, as the last expression of a developmental effluence, it betrays unforeseen qualities. If the universe contain anything mysterious, if it add to pure reason aught that betokens another and, as some would argue, a higher level, man must search his own heart for the clew to the unique riddle. The opaque depths of the natural order do indeed defy most cunning plummet; but in the recesses of the human soul elements flourish for which 'nature' appears to present no unmistakable precedent. So, by one of those amazing paradoxes, apt to herald the near presence of truth, the penumbra of belief hints the existence, possibly the solution, of problems which, did they belong to a strange 'external' world, would lie hidden irrevocably in the profundities of the intractable unknown. Thus, allowing for the imperfection of knowledge, we see, by a strange shift of outlook, that we may satisfy our passion through fulness of life, if not by fitting it to the Procrustes' frame of intellect. For, in his quest 
after an ultimate reality, man must either call a halt at immediate discretion, or carry appeal to his experience as a whole. The unknown that immerses him is at once most baflling and most hopeful preciscly within the elastic circle of his self-mediating spirit. "For what man knoweth the things of a man, save the spirit of man which is in him?" 1 And I am not aware that this, the human opportunity, manifests itself more characteristically than in religion, the activity that differentiates manhood most of all from the beasts that perish. Thus 'apprehended,' as the apostle says wisely, one dismisses the unknown that still lurks in the womb of futurity, by transforming original emotions into vital convictions. The surprising ability to universalize self, the individual, breaks forth and, idealism aiding, the believer descries truth in his acute sense of union with a perfect reality. In short, religion transfigures beyond aught else, because it divines that presence of the whole which alone endows the part with value and intimation.

If religion lack ability to penetrate the penumbra completely, at least it can diffuse a light wherein many dark places shine luminous. Moreover, the process neither originates nor proceeds by way

1 I Corinthians ii. 11. 
of ruthless dictation; it signifies for the simple reason that it is self-generated and self-sustained. In one angle of his experience, that is, man joins himself to ideal completion through the natural operation of his own spirit. Michael Angelo, who hid these things in his heart, so that he was impelled by them to his wonderful achievement, has recorded the movement with the profound insight born of personal sympathy.

"Yes! Hope may with my strong desire keep pace, And I be undeluded, unbetrayed.

For if of our affections none find grace

In sight of Heaven, then wherefore hath God made The world which we inhabit? Better plea

Love cannot have, than that in loving thee

Glory to that eternal peace is paid,

Who such divinity to thee imparts

As hallows and makes pure all gentle hearts.

His hope is treacherous only whose love dies

With beauty which is varying every hour.

But in chaste hearts, uninfluenced by the power

Of outward change, there blooms a deathless flower That breathes on earth the air of paradise."

Reduced to cold prose, this means that religion possesses momentum to pierce the penumbra in degree as it rounds itself out in imaginative aspiration. Its creative prescription provides a foretaste - our only one, as all saints would attest — of final 
truth. If the harassed and bruised self, sensible of utter imperfection, can cheat the dreary doom decreed by a blind Fate, it has but a single resource. It must master its helplessness by consecrating its career to something perfect which it perceives, as in a looking-glass, at the centre of its own being. Tied by the body to the ambiguous earth, it nevertheless claims citizenship in heaven by virtue of undoubted power to soar thither. Its distinctive genius displays itself when, breaking through the penumbra of knowledge, it grasps reality, as it must account reality, in the penumbra of its own irradiating harmony. Intensely sensible of failure, dejected by defect, it yet creates faith that at once justifies failure, and renders the necessity of defect tolerable. Accordingly, it is encompassed by no forbidding mist of things unknown, but by the stimulative air of a larger experience wherein knowledge plays a subordinate, if indispensable, part in the middle distance. Like clouds in an autumn twilight, intellectual skies are never the same for successive moments; but the reason for religion abides unaltered.

"And at his side we urge, to-day,

The immemorial quest, and old complaint."

As in the elder days, when Springtime, and Sun, and Ptah, and Ashur, and Zeus were mighty to save, so 
now, the same fears compel the same hopes, the same perplexities imply the same remedies, - the same individual proclaims, 'Lo, I am universal,' and so it is.

Thousands in our own dull midst would realize this were they not stupefied by that "torpor of assurance" which curses organized Christianity today. From their eyes, too, the eternal soul gazes out, and in faithlessness to its latent capacities because nothing will induce it to look in. Having eaten of the Dead Sea fruit served up by a utilitarian education that has lost touch with relative values, imagination has fallen upon numbness, and spiritual originality has sunk low. Unaware of its own dynamic thrust, the modern soul knows no awe, and so its heart is seldom enlarged. In its petty irreverence it worships the barren individual, and the universalism of its suggestive penumbra is veiled in a fog of picayune methodism, fit habitat for prosaic citizens untouched by passion, but no refuge for a living personality blessed with the liberty wherewith Christ and His prophetic forerunners have made men free. Assemble the master poets, painters, musicians, patriots, philosophers, lovers; put them to the question; ask them their receipt for power, for winsomeness, for revelation. You will find that, in all cases, it consisted in ability to raise 
self above self into unity with something worth permanent devotion. In a word, it was identical with religion, though less intense because its object centred, not in the perfection of reality, but in a symbol - beauty, colour, harmony, or other limited affair. Thus, if religion fail to touch us as they were touched, how can we sense its penumbra, how much more must we fall short of ability to pierce through to the truth it illustrates? For religion is nothing but the eternal witness within human experience to the present incarnation of God in the idealizing surge of man. Or, adopting Ruskin's great phrase, religion consists in "veracity of vision." By it the individual has become the thing he predicts. A human being encounters, or, rather, contains truth here; for, from a finite sectary, quoting the words of a tortured book, reciting propositions mumbojumbo, or clutching desperately at the skirts of a temporal institution, he is transfigured into a catholicized member of the perfect reality immanent in his own soul. Untrammelled by the factual superstitions of our wooden neology, veritable pagans enjoyed calm to feel this.

"It is not needful to lift up the hands to heaven, or to make petition to the temple-servants to permit us to come close to the ear of the image of God, as 
though he could better hear us there; God is nigh thee, God is with thee, God is in thee. Yes, I say again, a holy spirit dwells in us, to mark and observe our evil and our good; as we treat him, so he treats us. No man is good without God's aid; nor can, unhelped by Him, rise superior to Fate." ${ }_{1}$

The penumbra of belief, then, as diffused by the inbred freedom of the spirit, the permanent guarantee of religion, is riven by shafts of inward light that throw radiant beams upon truth and reality. Or, if you prefer the audacity, - and religion can never be audacious enough, - religion is the sole activity of human experience that renders truth and reality inevitable. But Religion, remember, not mental suppositions concerning it. For truth and reality are naught except as shot forth by man's psychical claim of right; they are always disembodied types of self-revelation.

Notice, next, that religion tends to simplify life; it snatches one from turbulence, and leaves him alone with primeval fact.

"All other life is living Death,

A world where none but Phantoms dwell,

A wind, a sound, a voice, a breath,

A tinkling of a camel bell."

${ }^{1}$ Ep. xli, Seneca. 
What may this import? Some judgements, indispensable in a region of space and time, have been left behind; need for them exists no more. For example, in dealing with ethical matters, it is impossible to avoid classifications that introduce approval and contempt. But the believer, though he contemn himself out and out, cannot forget the unity with perfection which is his already. A destiny so tremendous evaporates contempt, but not entirely. Condemnation preserves itself, but only in the mood that justifies such exclamations as, "What is man that thou art mindful of him? and the son of man, that thou visitest him?" 1 Approval, likewise, subserves no office here. The work is the Lord's, not man's. Accordingly, one ought not to anticipate that, within the penumbra of belief, logical propositions, ranged stiff and severe, will rule the conclusions of faith. And, to this extent, the dimension of religion may be termed supra-rational - not supraexperiential. Let us listen to what the foremost among living philosophers has to say in elucidation of this point, so casily and so constantly misconceived. I cite Mr. Bradley, because his ruthless dialectic admits of no partiality to the religious consciousness. The object of religion -

${ }^{2}$ Psalms viii. 4. 
"is neither an abstract idea in the head, nor one particular thing or quality, nor any collection of such things or qualities, nor any phrase which stands for one of them or a collection of them. In short, it is nothing finite. It cannot be a thing or person in the world; it cannot exist in the world, as a part of it, or as this or that course of events in time; it cannot be the 'All,' the sum of things or persons, since, if one is not divine, no putting of ones together will beget divinity. All this it is not. Its positive character is that it is real; and further, on examining what we find in the religious consciousness, we discover that it is the ideal self considered as realized and real. The ideal self, which in morality is to be, is here the real ideal which truly is." 1

In a range where the strait canons of reason meet the deliquescent touch of affection, desire, and will, experience at length sights truth, appreciates reality. From these it fashions itself a new life. Conflict still persists, but its incidental terms belong to a single whole, that forms the presupposition of their possibility. This whole, the transitive human spirit, possesses efficacy, accordingly, to direct its steps beyond strife to peace, beyond appearances to reality. The inner unity of a given selfhood exhibits its truth by degrees, mediated in a series of elements

${ }^{1}$ Ethical Studies, F. H. Bradley, pp. 284-285. 
indissolubly one through their existence in and for this selfhood. In each of the parts the principle of the whole operates in its peculiar completeness. That is to say, religion is ultra-rational, because, as a distinctive process of experience in its entirety, it cannot be reduced to a form of knowledge. Or, more explicitly, it intimates, and with authority, the presence of a disposition native to idealism. As noëtic self-righteousness would judge, it pleads guilty to mysticism. In this mysticism the penumbral feature of belief comes to potent birth. Man dares to step beyond the bare affirmation that the object of his utmost desire is the reality, and seals his faith by the bold assertion that no other reality exists save in this. The personal self-identification provides the foundation whose builder and maker is God. Here, finally, all obstacles beaten down, our common humanity agrees that it has grasped the substance of things unseen. Backslide it may, but never to the old pit of finite satisfaction. Life has ceased to be an interminable experiment, - has defined itself as an imperative summons to immediate participation in the complete ideal.

Belief sheds a penumbra where light and shade tend to mingle; so much may be taken as nearly axiomatic. It refers continually to a higher order, 
unseen yet pervasive, the incontestable touchstone of a worth that dispels degradation from all present things, and promises their ultimate renovation. Prosaic rationalism, with its abstract articulations at second hand, has misprized this view, sometimes in cavalier, one might even say slatternly, style. If faith is to obtain a fair hearing, its mystical reference must receive impartial treatment. It seeks no generosity, but it requires us to face its special synthesis of empirical facts. Misinterpretation ensues unavoidably if an attempt be made to swallow religion at a gulp, as it were. Alternatives press for consideration when mysticism becomes an issue. For mysticism happens to be one thing as a wrought system, another, and widely different, as an access of "man's delight in the work of God." We are compelled to distinguish, in short, between the fatuity of the philosophy and the inspiration of the mood. When the mystic thinker wings it into the empyrean, his religion is imperilled by very excess,

"Pinnacled dim in the intense inane."

But, on the contrary, his noble elevation partakes of the magic susceptibility inseparable from genuine religious conviction.

In the first place, then, systematic mysticism 
would lift men above this world, and abolish responsibility of the spirit to the stern demands of the llesh, would rebel against their hateful oppression. Overcome by sense of need for complete union with Gorl, it would desert the physical universe, to satisfy its aspiration through soporific musing upon an inelïable divinity. It would negate all relations of experience except those consecrated specifically by Absolute Being. Once more, in its intense anxicty to safeguard its pure Deity, it would extrude the 'One' from nature and, having depersonalized mankind, would reach reality in a 'Beyond' where its possible degrees had all vanished. "The soul must sink in the Divine Darkness, into the secret place of the Divine Abyss," as Tauler held. "There is no safety save in the Abyss," as Briçonnet taught. "Adventitious reward may come in the consciousness of having conquered evil and done good; but true reward, essential reward, is only in the wild waste and deep abyss of inscrutable Deity, in the union of the soul with sheer impersonal Gochead," as Suso preached. And, when a believer secks to know concerning this 'Abyss,' "he must be as one dead, he must see neither distinction nor difference. For all that is in the Godhead is absolutely one, and formless, and void, and 
interminable, and passive." So, brooding over the 'Abyss,' Master Eckhart, that mystic of mystics, affirmed: "Thereof we cannot speak. It is the simplest essence of existence, it is unknown, and must ever be unknown. It is the simple darkness of the silent waste. It is the utmost term." Whatever may be said, by philosophical or theological criticism, for or against these gyrations of ecstatic piety, they are at plain odds with anything like our common Christianity, which, following the evangelist, insists upon the practical character of religion. "If any man will to do his will, he shall know the doctrine, whether it be of God, or whether I speak of myself." 1 As a practical scheme of salvation, mysticism failed. He who must toil in order that those who depend upon him may live, is undoubtedly the subject of unrest, assurcdly experiences the frequent pressure of defect, and realizes the need for its removal. But how can he devote himself to the contemplation requisite? Set, as he is, amid certain social conditions, how is he, while performing his duty towards man, to work out his justification with God? Mysticism offers no answer, nay, dispels every hope of reply. For the worldly career, even in the tenderest aspects and holiest duties, is a continual 
defection from deity. Religion is identified with a specialized energy which beckons from obligations towards family and friends, towards country and humanity, back into the tiny circle of the single soul's desire to sink down into the abyss of infinite and indescribable non-existence. The blessing of an ideal capable of being realized even in the lowliest earthly tasks never so much as occurred to systematic mysticism. ${ }^{1}$

Yet, system aside, a mystic element surcharges the penumbra of belief always. But it is not to be interpreted as a logical construction, relapsing, like the philosophy, into predestined vacuity, but rather as the leit-motiv of the fiducial process. Faith protests against the rationalistic analysis that urges the ultimacy of mechanical judgements. To this extent it welcomes one obvious tendency of mysticism. In so far as religion sceks, and finds, reality only in the significance conferred upon every separate thing by the presence of a universal being, it affirms a position grateful to the mystic. As it adjudges experience, the final import of human life depends upon unity with God. For, otherwise, the individual fades to a meaningless spectre amid the recurrent

${ }^{1}$ Cf. Mediaval Mysticism, in my Aspects of Pessimism, pp. $5 \mathrm{I}-96$. 
clash of its equally meaningless fellows. Remove the universal, and opposition rules everywhere; cosmic intimation, dependent upon knowable interrelation of particulars in a single whole, would thus become an ironical phrase. The penumbra of belief, accordingly, bears no witness to a God manifest in dreams, but does intimate an elemental spirit whose ceaseless operation conveys the sole guarantee that any finite object can affect the last reckoning. Evidently, the mysticism of religion repudiates such folly as the disappearance of each in the 'All.' At the same time, the believer is moved by something alkin to this idea when he denies that an earthly phenomenon possesses self-sustained stability, and affirms that, as we ascend the scale of existence from nebula to man, God reveals himself in a growing and more adequate revelation, whose intercourse furnishes whatever truth the coöperant stages evince. This apart, religion could not achieve its most tranquillizing consolation the assurance that God confers inalienable reality upon men here and now. All representatives of religious genius have been forward to confirm this faith. And, I think, we must recognize their veracity to their own experience, just as we accept that of the naturalist or historian to his. Nay, 
the point can be pressed farther. We are bound to insist upon our responsibility to the conclusions of science and history, because they, too, partake in the quality of revelation. They grip mankind, and exercise sway, in proportion as they cease to traffic with pale abstractions, and concentrate upon affairs that form irreducible elements of cvents through which experients have actually passed. Suffused with the warm atmosphere of human devotion, they serve and ennoble the race, because they dignify aspects of life by justifying their reality in degree. The penumbra surrounds them after their kind, in that they

\footnotetext{
"Have each his own peculiar faculty, Heaven's gift, a sense that fits them to perceive Objects unseen before."
}

Similarly, religion certifies a new dimension. And, even though the mystic note ring louder here, we are committed to heed those whose ears hear it, just as much as we accept personal evidence for other exploits of experience. Indeed, contemporary thought confronts no more clamant problem than to state ard enforce this mutual recognition among the various activities through which, as a matter of empirical record, men live concretely. If re- 
ligion be mystic beyond all others in its fetch of imaginative creation, still, like scientific and historical enquiry, it forms one expression, among many, of the selfsame consciousness. If it prize direct emotion more than the clarified intellectualism of the ages, the truth remains that, for us at least, such emotion would have been impossible, lacking the reason. Each must lay its gift on the altar of the other. Besides, the mystical element in the penumbra of belief, so characteristic of religion, is attested by its practical results. A poor starveling of humanity crawls forth to beg bread, and scrambles eagerly for crumbs from the board of the prophets - very minor prophets often. But, let the mystic touch transmute him - he developes a personality of his own at once, and yet in such detachment from self that his very presence induces others to walk the more excellent way. He attains substantive selfhood by touching the springs of life in his neighbours; for he bears good news of a power that has rescued him from petty aims, and liberated in him that capacity to uplift which never appears till a man is recreated in the decisive choice of the eternal as against the temporal. I thank God I have been able to commune with this transfiguration in the persons of several who were my friends. For 
the experience proves, not merely that this universalizing of the individual is religious mysticism, but - what is incalculably more important - that it is also soberest fact. In its practical effects it bars the way, demanding that we settle its account as adequately as the others. In short, human nature shows more things than are dreamt of in the circumspect deliverances of the understanding. It exhibits man as a perfectly new, but nevertheless perfectly normal, being. ' Natural supernaturalism,' the postulate and conclusion of religion, wells up midmost our common life in no less potent measure, to say the least, than abstract dynamics or 'causal' historicity.

The Christian testifies that, in his experience, this dimension of the spiritual career reveals itself, not simply in a peculiar manner, but so as to manifest the complete truth of the relation between God and man in a normative fellowship. If his faith possess the root of the matter, he is prepared to affirm that, for him, Christ has become all that God need be for the total justification of his higher reality. Tremendous though the asseveration seem, it does not exceed the implications of the awful solemnities encircling our personal destiny. As far as earth fails from heaven, our souls, in their individual 

isolation, prove unequal to the 'God within,' and, in sheer helplessness, seek some One, "nobler and more splendid than is seen among men," " praying, "carry thou our yoke." 2 The dread position could be saved by no less bold adventure. For, "all human culture, natural as well as spiritual," giving the phrase its broadest sense, "hangs upon inequality of souls." 3 'Two profound questions therefore arise forthwith, and we must grapple with them as best we can. Their difficulty, if unparalleled, roots in the nature of the case. First, What is the Christian conviction? Second, What are we to think of the Christ on Whom, as Christians, we repose our unreserved confidence?

( I) To prevent misunderstanding, it seems necessary to observe at the outset that Christian conviction must not be viewed as if it were a statement of fact set foursquare in a few abstract propositions. Faith preserves vitality as a process of functioning in personal experience throughout its self-sentencing career. If we would fathom it, we Christians are in duty bound to revert from propositions to persons. Approached thus, as a powerful influence operative in voluntary consciousness, Christian

${ }^{1}$ Seneca, Ep. cxv.

${ }^{2}$ Cf. Virgil, $2 n$. i, 33 o.

${ }^{3}$ The Seat of Authority in Religion, James Martineau, p. 3 19. 
conviction is normalize primarily. How, then, are we to interpret this? First and foremost, as a definite attitude, yielding estimates that control practice distinctively. To render the meaning more definite, take science for example. It starts with presuppositions of its own. It adopts 'natural law' as a base-line, and proceeds to exclude contrary phenomena. Intractable material is omitted. By this judicial elision a unified result ensues, covering all amenable details without exception. So the numerous events that conform to the 'law' receive a new dignity; they rank as 'facts' now. Yet they are not honoured thus in their own right. They gain value literally, because capable of conjunction with other phenomena in the same sphere. The 'law,' that is, underlies them and, by enforcement of homogeneity, clicits the import sought by the investigator. There are no degrees; everything must descend to one level. Evidently, however, this method throws little light upon religious conviction. And the reason is not far to seek. In a scientific conspectus, all phenomena falling within the purview rank equal; no event can enjoy more value than another. But this never applies in religion. Conviction selects one factor deliberately, and enthrones it in experience. It becomes regulative, not simply 
in the possession of supreme value, but in that the value of other events is no more than derivative from the norm. As they rise to it, so they acquire reality. They ought to be as it is already. In other words, Christian conviction ejects an ideal, renders it prescriptive, and takes no pains to equate it with this or that transient episode. It may make light matters grave, and grave matters light. In short, a conviction is normative primarily, because it erects a canon of judgement, and condemns all alleged facts till they change their nature as it directs. It does not confuse notoriety with greatness, unctuous profession with saintliness, popularity with permanent achievement. The breathless interest converges, not upon the discovery of uniformities, but upon discrimination between the standard of value characteristic of the conviction and the affairs it enables the believer to estimate as worthy or unworthy. That is to say, a conviction rises to normative sway when it predominates as a rule of life, or rather, as a measure of the relative importance of factors common to life. The judgement affects degrees of validity, is not concerned with descriptive accuracy.

So, Christian conviction may be said to overturn many worldly estimates of ordinary things, for it 
denies that the value, attributed from other points of view, represents the true value. As Christians, we will (or choose) to weigh things temporal according to the dictates of our belief. We transfigure often, abolish sometimes, sure always that our criterion embodies jubilant truth. Or, stating the case otherwise, a single positive ideal sets the perspective, and casts its own lights and shadows into the farthest recesses. Possessed by it, we adjudge the reality of our nature to consist in a definite self-activity whereby we universalize manhood in persons puny otherwise. It contains the sole wisdom of life in the sense that it alone mediates the satisfaction demanded by men. Thus, for religion, but a single 'fact' exists; phenomena never rank equally on the same plane as with science. The terms of experience fill their places, no doubt, yet in such a way that existence itself can never be demonstrated fully even by summation of all its parts. A unity underlies and alters them. The conviction accordingly transcends incidental circumstances and, as the dominant regulative command set over them, assigns them their values in measure. A normative ideal, therefore, offers scope for the complete and free development of the deepest insights. Its manifestation is constant and ubiquitous - the 
little leaven that leaveneth the whole lump. The succession of events, described as 'history,' may subserve uses in illustrating its operation, but tells nothing about the problem of ultimate validity. Thus Christian conviction assumes most definite guise in the form of an immanent process of greater or lesser virtue for the upbuilding of religious manliness. It might be defined as a determination of the life within $a$ life. It persists as incarnate in men, they persist as they incarnate it.

But, secondly, What is this norm? It originates in the great dualism of self-consciousness - the contrast, even conflict, between an inner and an outer world. Confronted with the difference, Christians affirm that, as between these two, human beings, thanks to their very constitution, must seek truth in the inward part. Here we encounter a permanent distinction between 'grasp' and 'reach,' between 'is' and 'will to be.' Religious aspiration prefigures a richer, purer, completer selfhood, and commands us to take service with it. Moreover, in proportion as we gain acute awareness of its internal presence, we increase that tension of the whole being which I have termed religion. Devotion to this upper dimension of reality motivates the spiritual life. Messages concerning its nature 
emerge from it in the revelations of religious genius. A central authority, superior to all contrasts, scizes upon us and, as its exponents, we acruire significance altogether beyond our circumscribed ego. Our final value inheres in, as well as issues from, this penumbral power, and so we picree through the temporal order, as participants in a larger existence, "without father, without mother, without desceni, having neither beginning of days, nor end of life." 1 The old dimensions of past and future, of breadth and thickness, lose importance. And with what a curious result! Straightway we convict ourselves of sin. In his pulsating experience, the Christian is gripped by the swirl of a disturbance that may carry down no less than up.

"Er braucht's allein

Nur thierischer als jedes Thier zu seyn."

But the frightful possibility of descent discloses also the power of the normative ideal to capture the whole person. And so the appeal to a redemptive presence, able to save to the uttermost, attains poignant fervour. Alienation from an unseen Reality more potent than self-awesome in its intimacy beyond the most terrifying forces of nature -

1 Hebrewos vii. 3 . 
suggests, not merely its competence to mould everything to its own ends, but capacity to approach from within, and in friendly mien. Personal communion with the ripest actuality in our own souls works deliverance from their lowest impulses which, thus touched, display their dire ugliness.

"Those who inflict must suffer, for they see The work of their own hearts, and that must be Our chastisement or recompense."

A new judgement governs here, of such a kind that man comes to be the subject of a universalizing consciousness pervasive of every cranny in his character. Thus, he presents meaning just in proportion to his apprehension by it. Convinced of an implicit rest in God, the Christian proceeds to realize it explicitly in his daily walk. The homely becomes lovely, because love wills perfection in it, a perfection drawn from the object of its devotion. In brief, Christian conviction declares God to be the normative content of human life. No doubt every ethical religion befriends this conclusion in degree. But, so far as I am aware, Christianity alone has exercised boldness to assert that the ideal order finds its most complete manifestation in and through our race. Paradox of paradoxes though it be, Christians maintain stoutly 
the affirmative reply to the question put so pointedly, in another connexion, by one who is perhaps their greatest poet, -

\section{"can he use the same}

With straitened habits and with tastes starved small,

And take at once to his impoverished brain

The sudden element that changes all things,

That sets the undreamed-of rapture at his hand,

And puts the old cheap joy in the scorned dust?" 1

No doubt, sometimes, as the poet continues, -

"All prudent counsel as to what befits

The golden mean, is lost on such an one:

The man's fantastic will is the man's law."

Nevertheless, the conviction of "the sudden element," once felt, ranks foremost among "the oracles of vital deity." Accordingly, Christian faith teaches that temporal personality takes its place, not as a lonely subject entertaining belief about God, but as the veritable exhibition of a present eternal in the only form capable of being grasped by man - his own. Universality, always potential in self-conscious individuals, rises to manifestation in them when they enter spiritualized manhood. "Not my will but Thine be done;" when one can say and enact this, he is human indeed, but also more. He achieves

${ }^{1}$ Browning, in An Epistle, 1. $23 \mathrm{I} \mathrm{f}$.

$\mathrm{x}$ 
the same mind as the eternal, wills in godlike style. He confesses allegiance, not to an unknowable power without the order of experience, but to a sempiternal presence of the Most High to his will, that enables him to bring forth the bread of life for the nourishment of others. The truth of this God within the soul can be substantiated only by those whom it has transfigured so that they enlighten the world. Christian conviction, then, affirms a normative "maximizing of life," possible solely through the rush of a mystic effusion that produces the transitive originality wherein one unfetters himself, and elevates his disposition beyond immediate or finite interests.

But this implies, thirdly, that Christian conviction estimates the norm of man's being in terms of eternity - an allegation so preposterous that to many objectors it is inconceivable, so they say. Let us look at it for a moment. The question would seem to be, Can any interpretation be put upon the presence of eternity, or an eternal element, to human experience such that even faith, let alone reason, may compass some account of it? Christian conviction appears to me to require nothing less. And, clearly enough, the answer depends upon the meaning one assigns to 'eternity.' If it be convertible with mere endlessness, as is commonly supposed, and urged even 
by Christians, the enquiry may be dismissed forthwith. If this embody what we Christians believe, we may as well halt at once - for it can import nothing. Obviously, even the more conventional doctrine of 'immortality' does not insist upon simple length of days; it posits invariably a certain kind of being. I take it, therefore, that Christian conviction throws its stress, not upon a more or less babbling continuance, but upon a concrete existence expressible in experiential terms. And existence, once more, can scarcely be predicated of 'laws,' 'propositions,' 'principles,' and so on. It is an indefinable condition peculiar to things and persons in time. In time - "aye, there's the rub." Theologians have intensified the difficulty of the problem unduly in their anxiety to 'prove' the reality of God's existence. They have set this in apposition to the existence of events in time, an unreal existence, they assert. We may dismiss this procedure as irrelevant to practical conviction. Every lover thrills to the reality of the object of his affection; every artist to the reality of beauty, and so forth. Moreover, these occur in time. But this fails to negate eternal existence, because a fact in time, and eternal existence, though far from identical, may be related. In short, Christianity countenances no such ascetic separations. 
What Christians affirm is that, fundamentally, all existence, which enjoys symptomatic reality, must be eternal existence, or existence in and to an eternal. That is, it derives its right to weigh in the reckoning from an eternal factor functioning in it now; the timeless whole confers reality upon the temporal parts. This implies, once more, that what we call 'time' is an illusion of our individual, as distinct from our universal, nature. We obtain partial glimpses through sense, but fall short of ultimate existence as it is actually. Here we evidently come upon a figure of speech, a poetic statement ejected by imaginative creation, a 'way of putting it.' And in this Christian conviction cannot find rest; that is, its complete implication must travel farther. Personally, I feel sure that it does. It means to assert that the value of things, and most emphatically of men, determines itself by their indifference to the transient details of experience, negatively, and positively, by their subordination to purposes believed to be divinely inspired. This intimates plainly that an adequate realization of the eternal ideal may eventuate within human character. ${ }^{1}$

${ }^{1}$ A view closely akin to this has been elaborated by the most eminent theologian of our communion, Dr. W. P. Du Bose, in his The Gospel in the Gospels; cf. chaps. vi, vii, and viii. 
The gospel of a divine humanity would constitute such an event. Moreover, if this consummation were to overtake our kind, it could never have begun, and can never end - for an eternal abides without these temporal distinctions. Besides its apparition would not cancel or remove mistaken judgements of value still operative with men as a result of their sensuous envelope. The mirage of the world would flourish still, full of loveliness to the eye, although the spirit knew it for a deceptive show. In short, Christian conviction points to an eternal existence consisting in a certain quality of being, without specific reference to time past or present, possibly without reference to time future. So far as a detached object succumbs to temporal bonds, it misses completion, and must be delivered somehow from this servitude, no matter how inevitable it may seem. Hence Christians represent their eternity as a way of life, consummated "from before all worlds," but also as something to be consummated in them because fallen individuals - in an eternity to come. Their regnant belief insists that the one, free from temporal illusion, must save from the temporal illusions which the other cannot escape. So it may be said in passing that, if Christianity offer a problem to philosophy, it is not the trumpery puzzle of end- 
lessness, but the extremely subtle question of the relation between imperfection in a time-series, and another kind of existence, to be extricated from this, in freedom from the defects that time prescribes.

Our religion permeates us, accordingly, because it lends us faith to comprehend that we enjoy normative fellowship with the eternal even amid the appearances of time, and that, their vagaries overpassed, we shall become our true selves completely, because so unified with this eternal as to be incapable of estrangement from it. It teaches us to believe also that this intimate communion with the eternal has been realized within human experience, thanks to the spiritual clarity of one whose religious wisdom temporal disorders, at their cruelest, could not obscure. Thus we feel settled in the faith that our lot holds no ultimate hope unless the episodes of time be rendered means of consecration to an eternal; and that this consecration is in Christ, may be in the spirit of any Christian convert, must so be for him in the state where he sees face to face. Now all this is quintessential idealism. You cannot 'prove' it by reference to external things, or by appeal to the literal record of a dead past. "Thou, God, seest me!" No one can fathom this confession who lacks acquaintance with it from the inside. If one under- 
stand it, he rests his case upon a vital experience of a power that changes will and emotion so that they win intellect over to a new range of values; if not, he remains ignorant, as Christianity judges. For the seer, the eternal constitutes the timeless end of the personal; and a person is personal because his seed from the eternal renders him such. As Carlyle says, "the situation that has not its ideal was never yet occupied by man .. the ideal is in thyself." Seize it, be seized of it, and the vision of your true worth becomes the normal fact of common day. Christendom has supplied many careers in point. This humiliation of God to their nature crowned them with the only immortality whereof man has assurance.

Christian conviction, then, presents at least three elements. First, it is normative, in that it erects a standard of value whereby it rates the religious worth of every event incident to life. Secondly, this standard pivots upon an ideal present to the inner vision. Thirdly, this presence is conceived as the witness of our eternity; when, having freed ourselves, through its efficacy, from the thrall of time and sense, we come to realize that only in the dimension of the spirit can men flourish so as to accomplish work destined to deathlessness. So far I have tried to 
describe the indescribable. For Faith lives in radiant joy; set it to think, and it shivers in the unaccustomed atmosphere, with woe-begone gestures that seem eccentric or mayhap foolish.

(2) Hence, when the Christian proceeds to confer substantial rather than verbal embodiment upon his faith, he turns forthwith to Christ. And the question arises, What are we to think of Christ, or rather, To what do we testify when we declare that, in Him, the fundamental elements material to this conviction reach supreme expression?

You must understand, to begin with, that the profoundest thinkers and holiest saints of Christendom have recurred to this problem continually to confess failure. It would be gross presumption on my part were I to suppose that, without a tithe of their ability, learning, and spiritual enrichment, I could succeed where they have found themselves baffled. The truth seems to be that the problem eludes operose solutions; anyway, it mocks pure intellect. I cannot attempt more than an indication of my manner of approach to it. Here, too, my narrow limits confine me to the barest suggestions. It may conduce to clearness if I cite three current views with which I find myself unable to agree.

Some devoted and devout students of Christianity, 
who form an influential school just now, teach that, after it had passed from Palestine into the Roman Empire, our religion was vitiated by adoption of ideas and tendencies peculiar to Greek thought. Accordingly, they have raised the cry, 'Back to history,' and have laboured to arrive at intimate relations with the Jesus of the Gospels by going behind these pagan accretions. Careful use of this method may result, assuredly, in a more definite, because less doctrinal, conception of our Lord's teaching. But, while it would be sheer ingratitude to lightlie these investigations and their important consequences, it is quite another affair to train with their representatives when they insist that in this manner, and in none other, can we answer the question, "What think ye of Christ?" Valuable as a historical discipline, the critico-psychological method seems to me to err in two particulars. On the one hand, its estimate of its own possibilities is too optimistic. As we have seen, we know little about the biography of the earthly Jesus, so little that we cannot hope to reach the eternal Christ even by most minute study of the New Testament accounts. Christianity persists in all that Christ continucs to be, far rather than in what the man Jesus did during the recorded fragment of his temporal career. The 
fulness of the personality transcends our most accurate determinations of the teaching as reported by disciples. We may, indeed, recover something of the individual verisimilitude, here a little, there a little. Some portions of the story may turn out historical indisputably, others - probably a larger total - may have to be rejected as fictitious, and still others may prove an admixture of history and imagination, so closely interwoven that separation is impracticable now. But, in any case, the universality present to the living Person escapes this process; happily it neither needs, nor can submit to, any such recovery. It abides intrinsic to the mystic penumbra of Christian faith. Criticism might very well regain for us some of the traits peculiar to Jesus as he walked in the flesh. But it does not thereby acquire exclusive patent to uncover the ideal Christ, Whose contingent symptoms these traits were. So, on the other hand, the critico-psychological method is too pessimistic in its estimate of the actualities - too barren, analytic, oblivious of the constructive response induced in the regeneration of Christian men. One incident, more or less, would aid our vital Christianity scarce a whit. The doings of Jesus are wrapped in obscurity - and this is far better. His teaching we know in sufficient measure from the tenour of the 
documentary sources. But the metahistorical Person, as it governs down the ages, we can learn only from those whom He assimilated to himself. 'This should be obvious to anyone who has tried to commune with the early disciples. They at least sensed the universal in Christ by help of some other witness than companionship with the man of Nazareth. For my part, I am ready to accept this single fact as decisive against critical agnosticism.

Once more, nothing could be less helpful for our problem than the widespread, semi-popular rationalism that sees in the Life of Christianity no.more than another Socrates, Marcus Aurelius, or Spinoza - a remarkable moralist. This construction 'explains' Christianity by the familiar expedient of omitting nigh all that originates the need for explanation. For Christianity consists, not in a school of thought, even an ethical school, but in Christ's power to reproduce Himself in any man. His way of life contains the condensed secret, and formulates the principle of solution. He guaranteed, and continues to guarantee, a relation of the individual disposition to God unexampled elsewhere, and capabie of 'proof' only as brought to fresh illustration in Christian characters. Morality forms but one of many events contingent to it, and meets transfiguration like the rest. 
Finally, if the rationalistic conception be a parody because extracted from a chip, the vague humanitarian notion, still prevalent in some quarters, is just as lopsided. A generalized sentimentalism, wherever human interests are concerned, falls short sadly of Christ's plangent idealism. The yearning for man's temporal satisfaction, daily comfort or decency, and natural pleasure, does indeed accompany the genuine Christian attitude. But it issues from something far other - from a conviction concerning man's relation to God. This saves it from flabby benevolence, from green-sick gush, from the cant of vapid enthusiasm. These methods of approach, then, in their fecund kinds, seem to me failures, because they are too relative, too doctrinaire as of an age, too forgetful of the transitive, reproductive universalism that is Christ.

If so, what are we to say? My own feeling - for it is a matter of emotion and wish rather than of intellect -- may be hinted if I confess that, when faith flags, and doubts invest, I turn, not to the Synoptists, winsome though they be, not to Paul, although his matchless courage and magnificent self-devotion overwhelm one with shame, but to what I have called the pearl of great price in the New Testament - the Fourth Gospel. ${ }^{1} \quad$ The eternal ${ }^{1}$ See above, p. I5r. 
Christ is true man - man reborn after the spirit, "by a new and living way, which he hath consecrated for us, through the veil, that is to say, his flesh," as the writer of Hebrews saw. ${ }^{1}$ For us, in these latter days, at all events, the essential qualitative truth receives sufficient emphasis in the memorable admonition to Thomas: "Because thou hast seen me, thou hast believed: blessed are they that have not seen, and yet have believed." 2 What do we believe, then? Let Paul answer for us, and in his Johannine mood.

"The righteousness which is of faith speaketh on this wise, Say not in thine heart, Who shall ascend into heaven? (that is, to bring Christ down from above:) Or, Who shall descend into the deep? (that is, to bring up Christ again from the dead.) But what saith it? The word is nigh thee, even in thy mouth, and in thy heart: that is, the word of faith, which we preach." ${ }^{3}$

Be assured, Christ cannot conserve His reality for us, and continue no more than Jesus of Nazareth, crucified, dead, buried. He persists as the active presence that operates within, soul to soul, or we have lost Him beyond hope of recovery. For the Christian, human life on this infinitesimal planet is either a quantitative phantasmagoria, or is capable
${ }^{1}$ X. 20.
${ }^{2}$ John xx. 29.
${ }^{3}$ Romans x. 6-8. 
of being charged with awful responsibility as the fullest theophany patent in time, destined, moreover, to perfect completion through a divine humanity realizing itself untrammelled in the kingdom of God. And this divine humanity is achieved without flaw, once for all, by and through Christ.

The curious fancy has orertaken me often that, if we compare the Synoptists with John, they seem to be predecessors of Christ, he the veritable follower. The last verse of the Fourth Gospel indicates why. "And there are also many other things which Jesus did, the which, if they should be written every one, I suppose that even the world itself could not contain the books that should be written." The factual element in the earlier writers smacks of struggle, bows to local pressure, may be overset even; the personal touch of the later disciple flashes forth iridescent with flaming truth. John in foreign Ephesus, or his near kith, interprets the Person of the Master as universal life; he makes it the prius of the possibilities of a history that would spell cold prose otherwise. He attests it as precedent, primary, and reduces the biographical record to illustrative rank. His approach, that is, issues from the enthusiasm of transmuted individual experience. Or, the actual presence of God - the eternal - in Christ conditions 
the effort to comprehend the man Jesus. A metahistorical person, uplifted and ubiquitous, creates the importance attributable to a single Jew in time. The author of the Fourth Gospel has been seized of the conviction that Christ cannot be understood by any appeal to variable circumstances, and that these must be interpreted by reference to the impulsive power of the eternal existence shining through them. Completion of humanity prevails with him, not as a philosophical idea, not as a particular event accidental to a place or period, but as the internal organization of constructive efflorescence, always real and always regenerating. "What things soever" the Father "doeth, these the Son also doeth in like manner." 1 Here we have the Johannine approach; the believer adds to the record, now stereotyped and therefore chilly, his warmth of passionate devotion, and passes thereby from a historical one among others to a metahistorical, renewing force, incarnate finally in manhood. He assimilates himself to Christ, and in this assimilation the witness of the eternal, energizing personality becomes self-evident. In a word, Christ achieves place as divine through the consecration of His followers. The inexhaustible freshness it is that supplements the partial tale of the life 
on earth, and acknowledges therein a life from hearen.

This universality of Christ, in the concrete faith of His disciples who had not seen, solves the apparently insoluble problem of a God-man walking in Galilee of Judea. The agnosticism which alleges that the Prologue of the Fourth Gospel "is not the key to its comprehension," 1 contrives precisely to invert the situation. One suspects it for a mere foible of scholastic thinking. By his cosmic presence, in the exhibition of a redemptive and ubiquitous life in human kind, Jesus served himself Christ; but this, the ordained end, could not become apparent till believers, having perceived the Christ in and for themselves, developed ability to recognize what a universal and eternal existence might purport. This, the completion of Jesus' work, necessarily eventuated ere his divinity, as man's Christ, could enter the human spirit in triumphant victory. The validity of Christ, that is, broke forth from the 'One God' creative of history, not from any annalistic statement within history. Christ appeared in final reality, not during the period when "hitherto ye have asked nothing in my name," but when the

${ }^{1}$ A. Harnack, in d. Ztschr.f. Theol. u. Kirche, vol. ii, pp. 189 f. Cf. History of Dogma, vol. i, chap. ii, sects. 3-6. 
saying was proven, "Ask, and ye shall receive, that your joy may be full." " The Master evinced 'heavenly' (that is, universal or eternal) value, through the mystic facts evidential of His career after death in the souls of His servants. Here, at length, man discovered Him as the God within the soul, mighty to save. Thus, and thus only, it became apparent that no antithesis exists between God and man, but a perfect indwelling of the eternal in the temporal. Thus, too, Jesus passed over into the Son of God - the Christ with us. For, as Keim says, with penetrating insight, "He has filled up the gulf between the One and the Many which Moses dug and no prophet bridged over." 2

Unquestionably, this estimate of all that Christ is approves itself primarily to Christian piety. But it was never meant to accomplish aught else, hence the secret of missionary zeal. We are not saved by an opus operatum, or by a speculative genius, or by a hero, or by a demigod, but by the reproduction in us, according to our own original effort, of the spiritual manhood which Christ conveyed. Not that $\mathrm{He}$ needs anything at our unclean hands; nevertheless, our communion offers the only present certification

1 John xvi. 24.

${ }^{2}$ Jesus of Nazara, vol. vi, p. 429. 
of His transcendent potency. It seals the eternal in Him. "Know ye not that ye are the temple of God and that the spirit of Grod dwelleth in you?" 1 We do know, and this knowledge it is that approves the largest indwelling of the Spirit of God in the deepest convictions of Christians. Only to children of the flesh can incarnation intimate anything. With them it happens to be a normal event; in Christ they discern the full-throated message for which this event came into being, without which it goes to pieces as the most intolerable error perpetrated by heedless cosmic Fate. And so, for the Christian, through his transformed personal experience, Christ is "alive for evermore" 2 as the explicit manifestation of the normative presence of the divine nature - a nature implicit in man, if man is to be reckoned as a being who possesses any differentiating mark of his very own.

And the attestation? Any believer can furnish it. If Jeremiah could declare, "His word was in mine heart as a burning fire shut up in my bones, and I was weary with forbearing, and I could not stay," 3 how much more he who has made common cause with a 'Comrade-God,' a familiar among the sons of men. A human God was our imperative necessity.

${ }^{1}$ I Corinthians iii. $16 . \quad{ }^{2}$ Revelation i. $18 . \quad{ }^{3}$ xx. 9. 
From the plenitude of His nature, "touched in all things like as we are," our emptiness could be filled. Mystic though the penumbra of this faith be, it intimates the basal truth concerning our divided life. "For this cause came I unto this hour." 1

1 John xii. 27. 


\section{LECTURE VIII}

THE VALLEY OF BLESSING

READERS of the Old Testament will recall that the Chronicler relates a curious story, not told elsewhere, about a wonderful victory gained by Jehoshaphat, son of Asa, over the "children of Ammon, Moab, and mount Seir," although, at first, the king had been "dismayed by reason of this great multitude." 1 Success won, the Judeans "assembled themselves in the valley of Berachah: for there they blessed the Lord." Like them, we have found few substantial reasons to fear the dangers that seem to compass religion in these days. But, like them too, we must remember that the valley is no mountain top where we may dwell safely in serene disregard of the encircling world. Christianity, as Religion, may indeed bless. Nevertheless, we are fated to fare forth to our daily labours, and to meet many perplexities on their own chosen ground. Our faith will not avail us much if we fail to employ it actively, and this

${ }^{1}$ Cf. 2 Chronicles $\mathrm{xx} . \mathrm{I}-30$. 
without taking unfair advantage of bare conventions. Culture presses forward, developing new situations, raising fresh issues, and we hinder rather than help Christianity by reluctance to meet the onset of variation. Thus, in order to round out our enquiry, we had better confront several obvious difficulties. They are of a more or less practical kind, and often give the enemy occasion to scoff. Belief or no belief, we work midmost modern life and, despite wishes, are unable to comport ourselves as if we were contemporaries of Paul, of Augustine, of Baxter, of Pearson, of Butler, of Keble, or even of Brooks. We need imagination to recognize that we stand accountable as much for our good as for our bad deeds. In some ways, moreover, the stress of the good may prove no less severe than that of the evil. For light and shade blend here below. As Nietzsche said, "unfathomably shrewd is the stupidity of the good:" "myself I sacrifice unto my love, and my neighbour as myself."

First, then, if, as we have tried to see, Christianity represent the true central stream of religion, if, as some claim, it be the 'absolute' religion, Why has it failed, and failed conspicuously, to master the human race? The deepest shadows of the valley envelope us when we face this sullen fact. But there it stands, 
leering at our bright hopes, giving the lie to our fond assurances. Of course, figures are deceptive, and furnish no more than an approximation. Agreed that the various faiths of the world count $1,540,000,00$ adherents, Christianity in its many branches numbers but a fraction more than thirty-three per cent $520,000,000$. Even more startling is the situation in the British Empire, where Christianity occupies the third place. Of King Edward's subjects, 206,000,000 profess Hinduism, 75,000,000 Mohammedanism, 60,000,000 Christianity. ${ }^{1}$ In other words, our religion has made little impression upon Asia, the mother of immemorial civilizations, the birthplace of the ethnic faiths regnant now, the home of $900,000,000$ men. Moreover, to-day Islam rules the land which Jesus illuminated, the scenes of Paul's principal labours, the age-old empire where the greatest thinkers of early Christianity held sway, the places where Augustine met his epoch-making experiences, and its political metropolis was the capital of the first Christian emperor. It attaches Asia at the rate of from 25,000 to 50,000 converts per year, - perhaps many more, as some authorities

${ }^{1}$ Cf. Comparative Religion, its Genesis and Growth, Louis Henry Jordan, p. 573 f. I happen to know from an independent source that Mr. Jordan has taken the greatest pains to verify his figures. 
declare. Further, in Africa, it has scized upon the north, upon the rast districts of the Upper Niger and Upper Senegal, has spread south far down the east coast, and gains steadtily along the Atlantic fringe; so much so, that one-half of the continent is Moslem; two-thirds feel Mohammedan influences; thirty-six per cent of the population profess Islam; while, Copts and Abyssinians aside, Christianity must rest content with less than three per cent. Nor does the account close here. One would anticipate great success for Christianity in Hindustan, where the pav britannica affords protection and favourable auspices. Nevertheless, the British have not divined the inner character of their Indian subjects, especially on the religious side, and, as a consequence, Christianity has secured no grip, save in the Madras province of Tinnevelli, where I 50,000 of the 2,900,000 Christians resident in India are to be found. ${ }^{1}$ It suffices nothing to cast all this in the teeth of missionaries as a class. For, on the whole,

1 An apparent exception to this may be found in Malabar, where more than one-fifth $(57,000)$ of Indian native Christians are to be found. The legend is that Christianity was introduced here by St. Thomas. However this may be, it is undoubtedly ancient (sixth century, perhaps), and stands aside from modern missionary activity. Cf. The Indian Christiuns of St. Thomas, W. J. Richards. 
they are staunch to their profession, work devotedly, often amid most discouraging difficulties and, in India at least, have won respect, if not complete confidence, from every class. Black sheep appear amongst them, as is ineritable. But their very rarity excites vivid attention, and thus acquires importance out of proportion to ratio.

Anyone who has considered the subject without prejudice, and reviewed the astonishing figures, will tell you to seek the causes deeper. It is no part of my intention to discuss them now, for I am leading up to a larger question, as you will see directly. But I may indicate one or two points.

For instance, why should a religion of Asiatic origin miss appeal to Asiatics so thoroughly? ${ }^{1}$ The result is the more remarkable when one acknowledges that, beyond all men, Asiatics delight in religion, and evince extraordinary capacity for concentration upon things of the spirit. Well, every religion must express itself in what may be termed a polity. And, if Christianity drew its original impulse from Asia, its polity is Occidental through and through. As a consequence, it carries this polity with it in the persons of its representatives wherever

${ }^{1}$ Cf. The Naturalization of Christianity in the Far East, Edward C. Moore, Harvard Journal of Theology, vol. i, no. 3 . 
it penetrates. One laughs aloud as he considers the feelings of a high-caste Hinclu Pundit, who is asked to walk lock-step with a respectable bourgeois Englishman, or a conventional middle-class American, in order that he may participate fully in the blessing of a higher religion! The Hindu deems our civilization folly; nevertheless, we would have him 'civilized' after our fashion as a necessary accompaniment of christianization. We try to teach him the English language, to introduce him to English literature, to inoculate him with 'Anglo-Saxon' manners, to fill his head with Occidental science, - in short, we would have him turn his back upon his own ancient culture, so that he might hold up his head within the fair precincts of our faith. Needless to say, fatuity could go no farther. The riddle reads plain enough, - if there is to be Asiatic Christianity, it must come through Asiatics, Arab Christianity through Arabs, Negro Christianity through Negroes. We shall have to drop the futile task of cutting alien civilizations to our pattern as the prelude to religious conversion, and proceed to devise plans for their transformation from within by their own folk. And why? Take the first case.

An impassable barrier still separates Oriental from Occidental culture. Despite all the benefits - 
and any just man knows them for legion - she has conferred upon India, Britain has failed to lay vital grasp upon any considerable part of the population. In passing, the same may be said of Russia in the East. And the middle wall of partition is as much religious as aught else. Or, rather, it takes the shape of religion wrought into a complex social system. We concentrate interest upon objects in space and time, Asiatics upon timeless ideas; our life is individualized and secular, theirs socialized and theosophical. The master ideals of the two culture-spheres will not mix. Little wonder, then, that the Asiatic, proud of his immeasurable past, dislikes Christianity, the religion of a 'superior' people, who would disrupt his social system, and who will not, indeed cannot, intermarry with him or otherwise share life on terms of intimate equality. Our religion would render him a waif in his own land, an outcast from his kin, would leave him naked and raw amid the only civilization he knows or can appreciate. ${ }^{1}$ Need we be surprised, then, that, if dissatisfied with obsolescent Hinduism, shaken by our science, he joins himself to Islam, where he finds practical equality, and not a beauteous, verbal theory? Every thoughtful AngloIndian is aware that the Asiatic would be rid of 
British rule at once, not because it is bad, - its justice Indians admit freely (and resent!), - but because he would, above all things, return to bis old paths, would be himself, in short, and cease to pose at the behest of disagreeable intruders. Nay, likely cnough, the dumb millions have their reasons. The complete sterility of English education in India were enough in itself. The system has produced no native of first-class ability, and is responsible, possibly, for the significant decline of Indian originality in architecture, literature, art, politics, as also for the slow dissolution of the principal religion. To have relegated the Pundit to the background, and suckled the Baboo, is, indeed, a glorious achievement, calculated to arouse pride! Did not Rome succeed amazingly in a parallel way? Many other things might be said, but we cannot stay. Briefly, then, Christianity must express itself afresh, from within the Asiatic and African civilizations, ere it can hope to remove the huge blot upon its missionary success. We should learn to attribute past failure not to our religion, but to ourselves, its half-hearted and, sometimes, thick-headed upholders.

Now this raises a far wider issue. We share the accomplished blessing, but we are condemned to continue in the valley of life. And the question 
arises, Is Christianity, as we know it, to remain an abiding thing, finished and adequate, or is it possible that man must still anticipate momentous changes within it? This problem relates primarily to what I have called polity, and is therefore of practical interest mainly. Accordingly, it involves another, and theoretical, enquiry that may be put as follows: Is the 'absolute' element in Christianity fixed and static? Or, on the contrary, is it in process of such transformation that it may be overpassed some day? In the language of religion, Can the kingdom of God attain more concrete expression on earth? These issues may seem unusual, perhaps impertinent. Yet we cannot shake them off under temporal conditions. What I wish to urge is that, if Christianity lag, we its children must bear the blame, unless we muster courage to encounter even the most disconcerting phenomena. "The good are indeed saviours of society, but only as they find its sins in themselves." " Who supposes that even the best have exhausted the unsearchable riches of Christ?

It were superfluous to prove that religion and polity cannot be separated. The one manifests itself in numerous activities that would be impossible apart from the other. Accordingly, as they interpenetrate

1 Philosophy of History, Alfred H. Lloyd, p. 228. 
inevitably, they interact constantly, and contribute in common to many morements. On the other hand, the reason for this interdependence exhibits every sign of extreme subtlety - it has been stated in most various and conflicting forms. I am inclined to believe that, in the present state of sociological knowledge, a general, though not necessarily vague, description must suffice. A religion and (if you please) a secular polity agree in one conspicuous quality. They evince a formative tendency that no contingent events serve to explain. The controlling force in both attaches to a metahistorical element. It attests the operation of a power that cannot be referred to single individuals as their attribute. It is impossible to track the state to contingent events, or to abstract statements of belief, any more than the church. And, all things considered, it seems possible that we know this power best in group-life, even if, as also seems possible, any particular group illustrates aspects of the whole, and perhaps hides the complete verity. For example, in the eighteenth century, many rationalistic critics of religion were pleased to identify it with priestcraft. It was an evil in their eyes, but not unmixed. Bad as the ally of superstition against enlightenment, it might be good, notwithstanding, as "a bridle in 
the mouth of the sensual mob." Jejune as these notions appear now, they held a modicum of truth. If, in the life of a polity, some men - the ministers of religion, say - be set apart as the exclusive representatives of a definite activity, then you must anticipate that, from time to time, this very selection will react upon the organization in general. Emphatically, the interests of the official class may diverge seriously from those of the community, and to such a degree as to arouse fierce antagonism. The story of bureaucracy needs no comment. The phrases, 'high-priests of science,' 'magnates of finance,' 'mandarins of education,' and the like, serve to hint that the same process operates in other directions as well. Now this implies that, in the differentiations necessary yet accidental to polity, specialists are prone to forget their own origin. Their inmost life flows from "the general." So, if they seclude themselves or magnify their office, they imperil their dearest hopes. The moment any group stereotypes itself, and would limit the expression of the metahistorical principle ascetically to a disrupted part, an artificial condition eventuates, and conflict becomes inevitable. Needless to say, this very thing has overtaken Christianity more than once in the Western world, and always with 
the same result. The sequel - self-confidence has drawn opposition, and has been forced to abate its pretensions. One sees similar phenomena in other grooves - in science, for instance. Compare its present tone with that rampant a short generation ago; the raucous note is raised no more. And the moral would appear to be that religion, like everything else, must retain intimate relations with polity as a whole; socialization provides an essential seed-plot. It ought to incline away from itself, as it were, that it may enjoy, not rude health of outer estate, but real influence through the entire ethos. If it retire to its sacred precincts, unavoidably its idealization of the community will fall short of a thorough mission. Nay, things being what they are, the presence of a complex polity to religion acts as a defence against the conceits of archaism. The polity might well suffer from some species of Christianity; but our hearts' desire is that it succeed by the power of religious truth. Its very defects should offer security for the future of a militant faith.

Besides, such is human nature that a polity forms an indispensable instrument. For, as the philosopher would put it, religion needs opposition in order to pass through self-alienation, the painful prelude to fiiness for a fuller revelation. In our universe, 
absence of growth, of power to expand, is synonymous with death. Religion enjoys no exemption from this rule. If it would progress, in the sense of maintaining positive dominion, it must keep with society. In addition, the more it pervades communal affairs, the more it finds ready intercourse with the ideals and activities symptomatic of other spheres; that is, the more ubiquitously it witnesses the presence of the metahistorical power which never belongs to single persons or to sectarian groups. It is enhanced, because multiplied with other factors, not only incidental, but needful, to its saving career. Yet at a price. The polity develops many features that may retard, even when they do not vitiate, the religion. Hence a constant opposition marks the neighbourly existence of both. Neither can dispense with the other, and yet each tends to subserve its own distinctive aim. In short, while a polity is essential to Christianity, Christianity is not essential to this or that polity; so the ideals of the polity and the religion may diverge, even although alliance be necessary to the socialized ends of both. Thus it may be perfectly true that Christianity suits Occidental civilization, Hinduism Oriental culture, Mohammedanism Negro society, and, at the same time, it may be perfectly true that the 'absoluteness' of Chris- 
tianity remains unaffected. In any event, no one can deny that many characteristics of Western polity do antagonize our religion. And if, as some allege, the latter stands on trial to-day, it is no less plain that the former has reached the assize also. The one cannot be weighed without the other. The vast differentiations of Occidental life have resulted in partial seclusion of religion. As a result, the two must be brought into intimate coöperation once more, if further advance is to ensue. The growth of insanity and suicide, the awful ravages of alcoholism, the grave failure of the most energetic classes to reproduce themselves in due proportion, the diffused individualism and materialism, together with similar phenomena, indicate some practices within the polity discrepant from the ideals of the religion. So, too, many professing Christians are satisfied to govern themselves by 'legal' conscience. They apply one standard in business, another in the charmed circle of 'the four hundred,' another in political 'deals,' and guide the great body of their ordinary practice thus. Yet they know a different rule in the church - alas, too often theoretically. Differentiation within the polity renders them tolerant of smooth blackguards, of agreeable gamblers, of mannerly sensualists, of public trustees whose 
official career is a lie, the blacker for copious whitewash. Still, on the other hand, without the polity the religion can effect nothing. The Gospel is to the world surely. We need to translate 'Christian truth' into the language and deeds of daily life, in order that its salving influence may pervade the community. A religion effective from Monday to Saturday will speedily expose the hollowness of a religion paraded on Sunday. Christianity faces a new task in relation to contemporary civilization, and needs must adapt itself to an unprecedented combination of circumstances. To renew the polity, it cannot avoid selfrenewal in some shape. It is no static system, but an active process capable of endless recuperation. Either this or its efficacy belongs already with the past - not done away, indeed, but laid up in a napkin, like a venerated fetich, to work miracles on call.

Now, if our religion must express itself in a polity, how can it retain its 'absoluteness'? On one condition only: given a functional activity necessary to the superindividual existence of the polity, and performed by religion. Doubtless, the subject is obscure and difficult; in addition, students have not probed it to the bottom so far. Accordingly, I confine myself to a few hints. As we have 
attempted to see, Christianity stresses a universal factor in individual men. But, even as subjects of this universalism, they live in human societies which, again, bestow on them a secondary universalism variable from organization to organization. As a rule this political enlargement takes the shape of national or imperial pride. Here religion and polity touch. The former insists upon what I shall call the 'person.' No one rises to the distinctive level of personality till he betrays the presence of some power greater than self. His consciousness gives access to the play of a transitive force that at once enlarges and dissolves the separate, self-regarding ego. Thus man releases a loftier experience, that betokens motivation by an operative spirit absent in his unregenerate days. Or, to state the case in terms redolent of piety: "Happy is he whom truth by itself doth teach, not by figures and words that pass away, but as it is in itself." Taught thus, a human life receives consecration as a new outlet for the manifestation of spiritual efficacy. It ceases to be a means, and ranks as an end - for the sake of the vital message it conveys. Accordingly, religion would conserve the individual on account of the superindividual in him. It would save him, because he is a 'person' or may come to be one. 
Polity, on the other hand, would conserve the individual in relation to sociomorphism. It would value him as a means to the preservation of its characteristics which, after their kind, are also greater than himself. Religion struggles for the 'person,' polity requires the individual to struggle for it. In the one case, man reigns as the agent of universalism, in the other, he serves as its patient. Notice, both concentrate upon his psychical enlargement, but religion unconditionally, polity conditionally. Religion treats the 'person' as a perfectible whole, polity would use the socialized individual as a relative part.

The two agree, then, in a common tendency to universalize individuals. Further, religion cannot dissociate itself from the circumstances characteristic of a polity. So it would seem that, if Christianity is to retain its 'absoluteness,' it must perform the function of transforming the 'absoluteness' of the polity in such a way as to show that it also subserves the 'person' as an end. In other words, it has to operate so as to indicate that, just as the individual may be rendered a vehicle of the universal, and be thus multiplied into personality, the polity, even in its superindividualism, may be widened in like manner. Religion can safeguard its peculiar universalism only if it energize as a vital power permeating the 
polity throughout, and effecting tangible results which, otherwise, the polity could not achicve of itself. The metahistorical unity, common to religion and to polity, attains clcar manifestation in this way, and in no other. For instance, as a matter of record, Christianity produced modern civilization in the Occident. It functioned so that the polity felt the presence of a spiritual momentum such as could be generated only within an integrated society. Yet the society was elevated above its kind by participation in the religious idealism. For a polity is of one blood with its diverse members in this respect, it can support its temporary ills, frequent disappointments, and constant strains, if it sense responsibility to something immeasurably more august than itself. Religion secures compliance with this condition. The polity changes chameleon-like. But religion stands firm witness to the metahistorical unity, no matter how it may alter the xonic means whereby acute need for God is brought home to the 'secular' group. Thus, in so far as any polity holds power to perdure through time and chance, it has already become a religious organization. And, in relation to it, the function of religion is precisely to arouse consciousness of this truth, and to keep it lively. Need I add that, for our own civilization at least, 
we have no choice; the purpose must be effected by Christianity, if at all. Hence its 'absoluteness.' Moreover, as it fills its function, it awakens our responsibility to other civilizations, by their very nature petitioners for the same universalism.

But, some one will say, "the facts of political and social life seem to prove that a polity is quite secular, that, on the slightest pretext, it apostatizes easily, nay, completely. Christian peoples, several of them, worship force openly. Indeed, they hold might for right, although they may hesitate to make the ugly confession with their lips. Again, many of the 'directing classes,' mainstays of the church, serve Mammon obsequiously. In a word, thanks to your polity, Christianity seems to have gone to the wall.' True, but not true enough. We must pause to ask a question. What do these vexatious developments betoken? No more than this: the polity, thanks to the severe pressure that overtakes all such arrangements from time to time, has sacrificed its best ideals for the sake of immediate satisfaction, or momentary advantage. Those who worship Might shall die by Might - or reform, lest this evil befall them. Those who worship Mammon shall succumb to his canker, or repudiate him, if they would escape. Signs of these very consequences 
already so multiply and alarm that we are prone to declare, 'Occidental civilization is at the cross-roads.' Now, if religion function as I have attempted to show, it alone holds virtue to restore that essence of the larger life which the polity has bartered, misled by false values. We must always remember that Might and Mammon are worshipped just in so far as they can be spiritualized. Man never bows the knee to them, but to the permanent expansion of self - the benison of superindividuality which, as he fondly supposes, they are able to bestow. The devil makes an invariable appeal, he lacks originality entirely. It is ever, "All these things will I give thee, - the kingdoms of the world, and the glory of them." Not the relative values of Might and Mammon, but the absolute value, in relation to self, of the things they offer, elicits human allegiance. Accordingly, the clamant business of Christianity becomes quite apparent. It must unveil anew, even to seventy times seven, those higher reaches of enlargement, those sources of transfiguration from individual to 'person,' whence alone permanent elevation issues. Granted that, in the nature of the case, polity strays into devious paths, follows divisive courses, the more need for Christianity to divine its real end, and this under the 
3H4 MODERN THOLGHT AND THE CRISIS IN BELIEF darkest clouds that shaclow any moment. Even in its Casarism and Mammonism, the polity worships - it turns to an 'oversoul' in some sort, and detects raguely its birth from 'another world.' Imperfect absolutism of this kind can be cxorcised only through the true absolutism of religion. Christianity must open the eyes of 'commercialiom, and its numerous kin, so that they may perceive the actual source of the stability that guarantecs them their temporary triumphs.

The power of expansion characteristic of modern society comes from man's ability to universalize sclf. To reveal this in its ultimate nature is the splendid task of religion, ever old, yet ever new. For, as the ends whereto polity makes individuals the means differ from generation io generation, so too Christianity must needs originate fresh methods to enforce the right of the individual to end as a 'person.' It will preach subordination of group-ideals to ideal manhood, it will set forth the still larger life, by showing that adequate personalism depends upon intimate communion, in complete sincerity of purpose, with the Spirit of Perfection whence group-ideals also obtain any significance they possess. Amid the distractions of time and sense, many miss the truth that heroism lies, not in worldly might, or in 
crowding goods, but in the stern battle with self-will, won only when self has disappeared, to return with its solemn experiences worked out "as ever under the great Taskmaster's eye." If, as Fontenelle said, "our fathers made the mistake of hoarding up errors for our benefit," the reason is evident. They forgot the true universal, in devotion to particular and momentary aims. And we are equally liable to the same mischance, unless Christianity clear our vision so that it may penetrate to the essential being of our kind. Its plain mission, then, - and this within the polity, - is to suffuse the secular 'absolute' with the ennobling glow of the eternal, that all dross may be refined away. In other words, the polity - ours, or the Asiatics', or what not - affords another, and greater, opportunity to the religion. The momentous issues with which Christianity still tecms relate, not merely to the conversion of individuals, but to the regeneration of cultures. These things seen and temporal, just because they fill so huge a stage, call for more adequate 'absolutism' than we have realized hitherto. So be we are faithful to the gigantic trust, Christ begins His larger mission -the polity of to-day exacts more than ever from Him. To conquer, 'Christian truth' must be proven truth by us more thoroughly than by our predecessors of 
olden time. For, as a polity grows more complex, it tends to disperse the solidarity essential to its well-being, in a mass of competing group or individual interests. This happens to be the grave disease of Western civilization now. On Christianity devolves the duty of restoring the broken unity, by its regenerating universalism. Only thus will the polity develop those superindividual sanctions, incarnate by transitive personalities serving the ideal, that give it internal worth sufficient to lead its members to go to the death for it, if need be, and this gladly. Now, as of yore, if "there be fifty righteous within the city," or "peradventure ten," the Lord will "spare the place." For by these independent instruments, the operation of the eternal, salving ideal is assured, despite any depth of iniquity. No polity ever lasted in which some did not live to God; and if some, why not all, by their example in word and work?

We have every reason, then, to anticipate great changes within Christianity, because polity is in process of such profound alteration. The strain of society grows tenser and, with it, the temptation to treat the individual as a helpless means. Consequently, one must expect religion to invoke new powers calculated to convince latter-day men of 
the value of life, as in every case consecrated by the indwelling of the eternal. The polity demands sacrifice, and useless sacrifice apparently, more and more. If this subordination of the individual to a temporary, and therefore imperfect, universal cannot be justified by the spiritualization of the 'secular' group, then dissolution is as certain as sunrise. In the circumstances, the necessity for renewed and renewing development within Christianity becomes entirely obvious.

Is a permanent expansion of polity possible, under the so-called 'law' of evolution, except on a fundamental basis of religious idealism? Sociological science leads us to conclude that it is in the highest degree unlikely. Even the founder of Positivism voiced this view with perfect candour. For, the pervasive unity, essential to the process ("the eternal arms' that support, as religion would phrase it), underlies mere separate individuals, and provides supersocial supports. If we are nonplussed to-day, it is because, lost amid a multitude of minor interests, we lose sight of this. Talleyrand was right when, consulted by Larevellère-Lepeaux about a remedy for the inefficiency of sugar-water 'ethical culture,' he replied: "There is one plan you might at least try. I should recommend you to be crucified and to 
rise again the third day." Yes, the settings of civilization change, but human need of communion with an 'absolute' remains essentially the same. And, for this, Christianity must continue to provide, though with marked difference of emphasis, suited to the possibilities of assimilation. In brief, the details of life in a polity might well drive one to despair; nevertheless, man's staying power, that transmutes these details into significant and authoritative reality, evinces supersocial traits, shot forth from an upper dimension alone productive of thoroughgoing devotion. To unify the two, as need arises, constitutes the mission and the justification of religion for us, Christianity. For the polity can be saved only by defensible belief in self - and this never existed without belief in "a divinity that shapes our ends." Religion elicits and instils the loyalty without which human experience, even in the superindividual realm of a polity, crumbles into transiency. Here we labour in the valley of blessing. The play of comedy in tragedy, the load of tragedy in comedy, intimate no less.

The theoretical question, Is the 'absolute' element in Christianity in such process of change that it may be overpassed some day? would carry us far afield. If we can only see why it should be 
asked, we shall have done something. On the face of it, the enquiry states a paradox, one that emerges from the paradoxical character of self-consciousness. Everybody admits that self-consciousness compasses but a fragment of ultimate truth as a whole. Yet, on the other hand, we ask helplessly, Where else shall we look for this very truth? The microcosm of the universe, as reflected back by our experience, cannot be devoid of all reality in the last resort, so far as we are concerned. Something in self laughs at change, or the bare notion of unity becomes illusory. Nevertheless, "change and decay in all around I see," not least in self. Accordingly, the single solution would seem to be that, by the changes through which self passes, its inner unity reaches working immutability in measure. The old self, that seemed 'absolute,' finds itself overpassed in a new development, identical in nature, notwithstanding the interference of the process. The personal relations constitutive of originating manhood never alter their texture, if we have but skill to pierce their temporary envelope. Still, in expression, defect always seals or modifies them from period to period, and so they cannot but overpass this or that degree eventually. So, if the unity of God, unsullied by imperfection, fails of identity with any particular apparition of selfhood it 
results, therefore, that the indwelling of this unity with our souls, as it proceeds from less to more, must involve the possibility at least of such restatement of the Christian 'absolute' that it may overpass itself, and still preserve its synthetic touch unimpaired. A human revelation, or none, is practicable among men. Thus, the revelation may be stable, on the side of the ultimate power implied, and transitional in its human media. It would savour of impiety, for example, to attribute virtue to God; virtue ensues upon sin orercome. Yet sin plays an important part in Christianity, particularly in its conception of the relation between God and man. And theologians have often presented it as if it bore specifically upon actual alteration within the Divine nature. Now, this intimates no more than the double character of ordinary life. Blessed though we be, we still abide the question in the valley. Hence the paradoxical problem before us teems with possibilities, because, in the unavoidable circumstances, ambiguity besets Christianity. A couple of illustrations may suffice to show why, and to close our discussion. Necessarily, they are selected from theology. For, after all, the paradox deals with Christianity as formulated, that is, as ambiguous. There are Roman, Anglican, Lutheran, Reformed, Unitarian, and other theologies, 
for the reason that this or the other facet of religion may cease to shine, or may be the single luminous point.

As we are discussing the 'absoluteness' of 'Christian truth,' suppose we select the doctrine of God as our first example. All believers will assent to the great Johannine declaration: "God is a spirit: and they that worship him must worship him in spirit and in truth." 1 But, then, no spirit exists without process, and process never occurs in vacuo. So, one part of the environment wherein the process proceeds may be, often is, mistaken for the whole. As a matter of fact, the self-poised oneness of God has shut out other coördinate revelations frequently. But with little warrant from the Master. In the most wonderful of the many wonderful passages containing the charter of Christianity, ${ }^{2}$ John makes Jesus teach the disciples how they, as men in a world of men, may escape this error. "Nevertheless I tell you the truth; It is expedient for you that I go away: for if I go not away, the Comforter will not come unto you; but if I depart, I will send him unto you. ... I have yet many things to say unto you, but ye cannot bear them now. Howbeit when he, the Spirit of truth is come, he will guide you into all truth." 3 The temporary

${ }^{1}$ John iv. 24. $\quad{ }^{2}$ John xiv-xvii. ${ }^{3}$ John xvi. 7, I 2-I3. 
theophany, because in a human being, must needs pass, to be succeeded by a permanent and ubiquitous presence. For those who have not seen, as Jesus realizes, the reality of the Godhead will continue to persist through the unbroken activity of the Holy Spirit. Accordingly, it is not too much to say that, when we have plumbed these marvellous insights to their depths, we may read our own situation in a new light. Here below, in our stage and state, the effective presence, wherein Father and Son alike may be discerned, and known concretely, belongs to "the Lord and Giver of Life." Moreover, the resultant supersession of many conventional doctrines about God may prove a necessary accompaniment of our transformed knowledge of self and the universe. Nay, it may be indispensable as a development pari passu with our growing appreciation of the structure and function of human society. In any event, we begin to cross-examine ourselves afresh concerning the society called the church. And we may well ask, Is a vital conception of the church attainable apart from such a view of the office of the Holy Spirit as I have indicated? As a churchman, I understand my society to be the superindividual community enlivened by the constant intercourse of the Holy Spirit. Further, I am unable to see that, under other conditions, 
we are justified in regarding it as the peculiar organ of religion. If its existence mean anything, it is this - that in it Gol is known of Himself. So far as broken human experience judges, superindividual power can appear only in relations of persons; and they achicve personality, as we have seen, precisely by the transitive touch of that Eternal wherein, fairly enough, we may arow the Holy Spirit. But, then, this superindividual power attains its purest tension in a communal whole. "I am glorified in them." Consequently, God, as the Holy Spirit, becomes the 'absolute,' not merely for us, but with us. Dominated, as we are, by the idea of development, it is not enough that we sense the superindividual in self; we seck it also, and more richly, in the supersocial, whereby a man is fortified unto the larger life. And this manifestation the church, as the subject of the Holy Spirit, ought to offer in uncxampled degree. The greatest thinker of the nineteenth century understood the position clearly: "finite consciousness knows God only to the extent to which God knows Himself in it; thus God is Spirit, the Spirit of His Church in fact, that is, of those who worship Him." 1

Thus, while conserving the 'absolute' in principle,

${ }^{1}$ Philosophy of Religion, Hegel, vol. ii, p. 327 (Eng. trans.). 
it is quite possible that Christianity, quickened, as it must be, by the latest demands of Christian men, may overpass its venerable dogmas of the static, transcendent nature of Deity, and concentrate its insistence upon the operative process of the Holy Spirit, through the church, for the world. In this sense, it would liberate itself from a transient methodism, and proceed, as by a fresh burst of inspiration, to tell our epoch all things that ever it did. And many events are less likely than the establishment of 'Christian truth' on this wise.

Coming, now, to our second example, it is not impossible that our intellectual explanations of the immediate appearance of God in Jesus may be overpassed. Jesus was a man, born of the flesh under the law, and therefore finite in the same way as his brethren. He was subject to all physical necessities, and had human character no less than human frame. Hence, one of the ambiguities of Christianity attaches to the view, not uncommon in Christendom, that this particular finite contained the "whole fulness of the Godhead bodily." No doubt, the reason for such an interpretation is not far to seek. Ordinary understanding, or common-sense, always leans upon the sensuous. Nay, some peoples, of eminent influence in the development of Christian thought, 
have been unable to rise above it, all in all. For cxample, it masters most Roman and Anglican reflexion. Now, thanks just to its sensuous basis, common-sense misses the implications of God-manhood, by confining its attention to a single individual, as if this being, by some strange freak, alone enjoyed communion with the Eternal. It fails to observe that such a conclusion knocks the bottom out of religion. Jesus fell a victim to no such deception. He lived to do the Father's will. He manifested God to the utmost possible with men. For our sakes he became poor, and therefore drank the cup of sense to the lees. As a human experient, he served himself an incarnation of one type of the divine process - the most real for us, be it sairl. Nevertheless, he was no statesman, or philosopher, or naturalist, or poet, or artist. These types of revelation must be sought elsewhere. Yet, he gave the decisive answer to the riddle of existence, not from God's, but from man's side. It was essential that the problem of the practicable union between men and the Eternal should be made plain. In other words, stereotyped theories may be overpassed, if the stress of the Christian incarnation be shifted from the divine to the human factor. For our religion contains other truths, and, consequently, there is an obvious sense in which, 
on some readings of it, the incarnation may become a half truth. For, in Jesus, it was limited to time and place. That is, Jesus came to show, by his faithfulness to death, what Christ might be. His person is unique, but so are all other persons. When it had passed away, and not till then, believers were able to refine the humane element, and seize upon the essential idea, which remains, as Christ, to witness the life eternal.

To state the process - for it is a process - otherwise. You fathom Jesus just in proportion as you discern in him a normal and not an abnormal (thaumaturgic or pagan) apparition of the Eternal in human nature. He preferred no claim to stand in place of God. This broke forth, and inevitably, from the awakened consciousness of the disciples. In like manner, we contemporary disciples, through whom Christianity energizes now, derive the Godideal from him. Jesus homo has long given place to Jesus salvator - Christ. Our need 'proves' the divinity of Christ, for our devotion, according to its ratio, evaporates the accidental and physical, leaving only the Divine Person. The adaptation of Christianity to man's necessity, and not the static unchangeable character of a Syrian peasant, embodies the benison. In Christ, human nature descries the 
way wherein it may walk, so transcending its own frailties as to arrive at renewed unity with the God Whom the world had lost nigh irrevocably.

Thus Christianity preserres its 'absoluteness' in the sense that it remains impervious to attacks from without. And, if we could but realize the liberly wherewith Christ hath made us free, we would understand that there are no such things as attacks from within. For the complete truth of religion issues from its derotees, each building his little bit of the opulent whole according to his God-given power, or purity, or mental sweep. They keep it in process of constant enrichment and, on the contrary, such are their responsibilities, reduce it on occasion to the level of uninspired, even repellent, prose. On this wise it partakes of that change without which the vital presence of operative spiritual reality sinks to a flatulent verbalism. Be sure, 'Christian truth' envisages a career, does not dictate a logical judgement. Accordingly, from generation to generation, this or that feature of the life glows in high light, while other traits lie in shadow - mayhap because they are overpassed. As Hegel saw, we must rise beyond knowledge to faith. "If we say nothing more of Christ than that $\mathrm{He}$ was a teacher of humanity, a martyr for the truth, we do not occupy 
the Christian standpoint, the standpoint of true religion." 1 Thus, paradoxically, it boots nothing to assert the exclusive presence of God in this or that man. "The teaching of Christ taken by itself belongs to the world of ordinary figurative ideas only, and takes to do with the inner feeling and disposition; it is supplemented by the representation of the Divine Idea in His life and fate." 2 So, the static conception is left behind when we detect the eternal Christ in the man Jesus. The cross is the baptism of human consciousness into Christ. For those who have not seen, there is no Epiphany without Easter. We overpass the historical accidents and, piercing to the 'absolute' that makes them possible, retain it as 'absolute,' no matter in what fashion our historical accidents may persuade us to represent it most effectually to our hearts. The blessing abides one, but ever amid the chances of the valley.

But all this brings us back full circle to the point of departure in the Introductory Lecture. There are intellectual constructions of belief necessary to 'Christian truth,' and they alter with the flight of

${ }^{1}$ Philosophy of Religion, vol. iii, pp. 77-78 (Eng. trans.).

${ }^{2}$ Philosophy of Religion, Hegel, vol. iii, p. 85 (Eng. trans.). The italics are mine. 
years. For instance, the clamant question to-day is not, What shall $I$ do to be saved? The 'other world' keeps too closely with us for this. Modern thought refuses to endure a dual universe; Spirit is unseen Nature, Nature is unseen Spirit. In our present condition, we rather ask, What is the perfect society? And, to answer it, admitting the fundamental postulates of religion as I have tried to sketch them, we cannot but travel beyond ancient transcripts, which become religious dangers when they erect barriers to every movement. But we fare forth thus in order to obtain closer walk with God. Christ rules, not the past, but our future, if we will to become, after our clearest vision, as He would have us be. It avails naught to imitate bygone thinkers, or even saints. The message gushes from our inward consciousness, to receive heed from us as we veritably are, or keeps the dead, decent level of a tale that is told. The cheering assurance, given by one of the several New Testament prophets who seemed to foresee our straits, possesses authority as pertinent to the twentieth century as to the distant day when it was set down first. "And all these, having obtained a good report through faith, received not the promise: God having provided some better thing for us, that they without us should not be made 
perfect." I Life eternal is a present state, ours to take or leave. As Christians, we gain this certainty by adoption into Christ, Who has proven that self, in its ultimate reality, enjoys free course only when the Eternal power functioning within it transforms every fibre of its being. But, reverently be it said, even the Eternal can accomplish nothing unless we meet it more than halfway.

Seen through the prism of intellect, as the transient generations must see it, 'Christian truth' yet remains one in whiteness of simplicity. "I in them, and thou in me, that they may be made perfect in one." 2 That is all! And, because all, capable of endless restatement, of multitudinous application. We support life in the Valley of Blessing, or curse it in the Valley of Hinnom, where the fair palm trees mark the smoke ascending from the door of Gehenna. ${ }^{3}$ Like other Christians, I cannot 'prove' these things, any more than I can 'prove' my own existence. But I am able to say humbly, I know. I am saluted by the discordant shouts of the old, old quarrel between the 'head' and the 'heart,' a duel destined to last with the human race. But the two could not disagree unless they belonged

${ }^{1}$ Hebrews xi. 39, 40.

2 John xvii. 23.

${ }^{3}$ Cf. City of the Great King, Barclay, p. 90. 
together. Patience with the plea of each alone will set the door of truth ajar. For neither has reason to say to the other, "I have no need of thee." Thought, without emotion, never accomplished anything permanent; emotion, without thought, never escaped the young folly of self-love. Slight either, and you seek trouble; give heed to both, and, happily, you may begin to perceive that they prefer equal title to membership in an ampler whole. So, in these Lectures, I have let the 'head' pursue its own course to the bitter end, only to find that, whatever the end, the 'heart' refuses to rest satisfied. For religion happens to be one thing, thought about religion a vastly different affair. Yet we are compelled to think about belief. Indeed, the practical character of Christianity requires to be brought home by some species of reflexion. Practice 'proves' truth, but practice formulated by the 'head.'

What else can we gather from the illustration with which I may be permitted to close? Let me lift the corner of a veil that men keep down generally, and you will see what I mean. If some poor souls, the bloom of youth still ruddy upon them, came to you, and confessed, with the awful shudder conveyed most faintly by physical gesture, "We have been at the very gates of hell,' or, 'We have seen hell incar- 
nate,' you would know. Fortunately, or unfortunately, I have encountered this satanic work more than once and, like my boyhood friend, Henry Drummond, "have felt that I must go and change my very clothes after the contact." 1 Here we have another process, down, not up, but, in its subtle movement, identical essentially with the Christian ascent. For, "identical conditions produce the hero and the coward." " He who exclaims rashly, "Evil, be thou my good!" also senses the eternal in self, if to dire purpose. Now, ask the father of any vicious lad, the mother of any light girl, whether these things are true, whether they stand in need of 'proof.' You will find that they know, alas! The power of creative emotion witnesses itself; and this power, at its tensest, patient to endure from day to day through the commonest worries of mortal chance, forms at once the supposition and the achievement of any 'Christian truth' worth the name. "Inward and spiritual grace" shines by its own light. It knows, yet is unable to explain, recognizing that explanations fail to satisfy the 'head,' because, manifestly, they fail to compass the 'heart.' The one knows, but during a moment

1 The Life of Henry Drummond, George Adam Smith, p. Ir.

${ }^{2}$ The Gospel in the Gospels, IV. P. Du Bose, p. 89. 
only, for, in the nature of the case, the other punctuates every proposition with discontent; and then a new effort at truth becomes inevitable. Fresh sheaves are fetched to the threshing floor daily, otherwise the kernel of ideal, eternal fact would go to powder, and lose its living essence amid the elusive, superficial chaff. But we, the latest harvest, must supply new grain for sustenance and seeding, even if its value may not have been struck as yet.

Nay more, on this threshing floor those who pulsate with the sacrificial throb of the race hasten to take the shoes from off their feet, for the place whereon they stand is holy ground. Here the elemental human spirit has been released through ages, to live on at this moment an inherent part of the palpitating present reality. Here, for the Christian consciousness, the eternal Christ inhabits, a pervasive influence able to mould all souls to its translucent nature. Here men hang their picture of the Christtype, the wistful shadow brooding on the face, because $\mathrm{He}$ knows only too well that His brethren must continue in His sufferings till the world's end, so be they would achieve some vital share in His potent wholeness, and learn from it how to

"Give consolation in this woe extreme," 

wrought by the cold touch of the abstract intellect. Here the captains of our temporal strife meet martyrdom in their transitive personality. As for Him, so for them,

"The age in which they live Will not forgive

The splendour of the everlasting light

That makes their foreheads bright, Nor the sublime forerunning of their time."

The glorious unity wherein they are thus lost, to find their truest selves, scals the promise of that final consummation, the Kingdom of Heaven, now in the winning. So His creation striveth - creating Him. And, if the mystics be few, the wandbearers many, let us remember constantly that the few must receive from the many that human extract whence they distil their message of new hope, bringing the Christ near, because expressing $\mathrm{His}$ secret in contemporary language, moods, and aspirations. 

Date Due

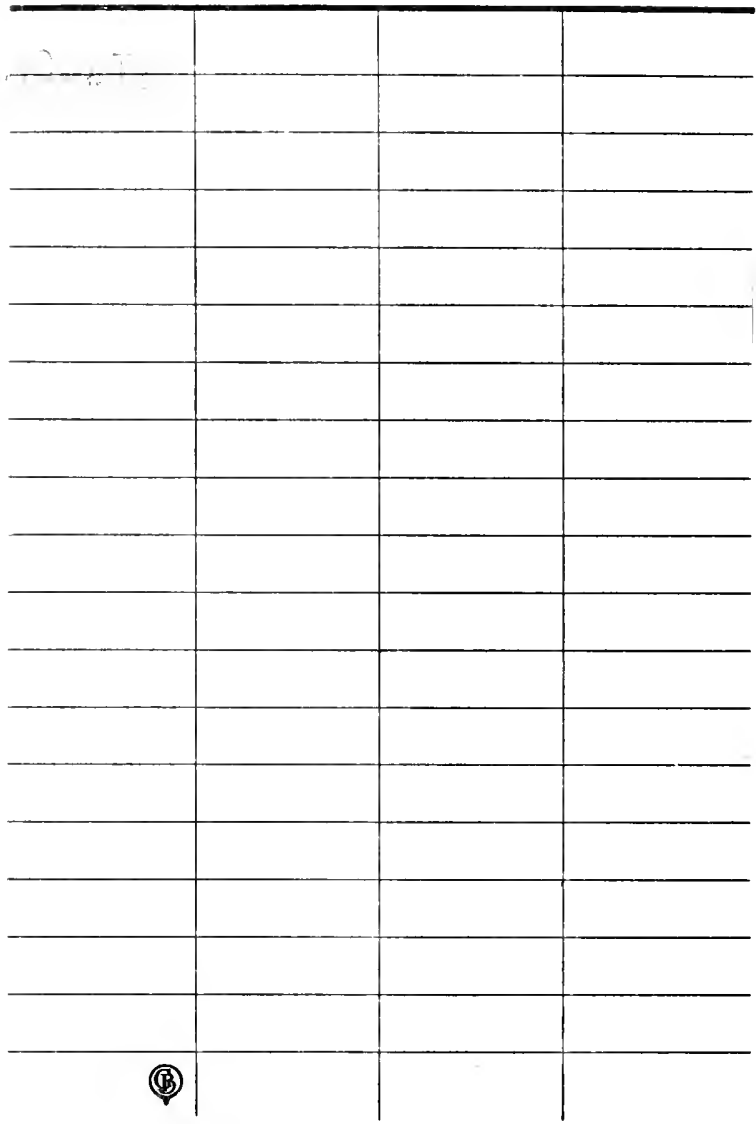


